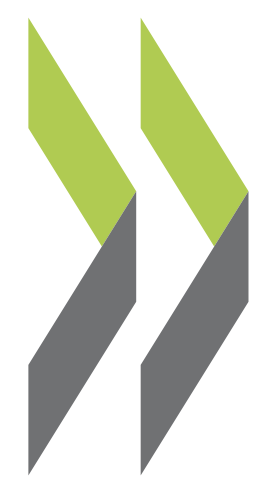

OECD Economics Department Working Papers No. 1661

\title{
Improving skills to harness the benefits of a more open economy in Brazil
}

Robert Grundke, Jens Matthias Arnold, Matheus Bueno, Priscilla Fialho 
ECONOMICS DEPARTMENT

\section{IMPROVING SKILLS TO HARNESS THE BENEFITS OF A MORE OPEN ECONOMY IN} BRAZIL

\section{ECONOMICS DEPARTMENT WORKING PAPERS No. 1661}

By Robert Grundke, Jens Matthias Arnold, Matheus Bueno and Priscilla Fialho

OECD Working Papers should not be reported as representing the official views of the OECD or of its member countries. The opinions expressed and arguments employed are those of the author(s).

Authorised for publication by Alvaro Pereira, Director, Country Studies Branch, Economics Department.

All Economics Department Working Papers are available at www.oecd.org/eco/workingpapers. 
OECD Working Papers should not be reported as representing the official views of the OECD or of its member countries. The opinions expressed and arguments employed are those of the author(s).

Working Papers describe preliminary results or research in progress by the author(s) and are published to stimulate discussion on a broad range of issues on which the OECD works.

Comments on Working Papers are welcomed, and may be sent to the Economics Department, OECD, 2 rue AndréPascal, 75775 Paris Cedex 16, France, or by e-mail to eco.contact@oecd.org.

All Economics Department Working Papers are available at www.oecd.org/eco/workingpapers.

This document and any map included herein are without prejudice to the status of or sovereignty over any territory, to the delimitation of international frontiers and boundaries and to the name of any territory, city orarea.

The statistical data for Israel are supplied by and under the responsibility of the relevant Israeli authorities. The use of such data by the OECD is without prejudice to the status of the Golan Heights, East Jerusalem and Israeli settlements in the West Bank under the terms of international law.

(C) OECD (2021)

You can copy, download or print OECD content for your own use, and you can include excerpts from OECD publications, databases and multimedia products in your own documents, presentations, blogs, websites and teaching materials, provided that suitable acknowledgment of OECD as source and copyright owner is given. Requests for commercial use and translation rights should be submitted to PubRights@oecd.org 


\section{Abstract/Resumé \\ Improving skills to harness the benefits of a more open economy in Brazil}

As Brazil is significantly less integrated into international trade than other emerging market economies, opening up to trade has significant potential to create jobs that are more productive and better paid. At the same time, this will be associated with structural changes and adjustment costs. Some workers are required to move to more productive firms, change occupations, sectors or even location. In particular, low-skilled workers need to upgrade their skills to move into newly created medium-skilled jobs in expanding firms and sectors. Workers who stay in their jobs will face similar challenges as firms upgrade production processes towards more advanced technologies. Well-designed and well-funded training and adult education policies, combined with effective social protection and employment services, can go a long way to mitigate adjustment costs for low-skilled, unemployed and informal workers. Evidence suggests that training policies can make a real difference, provided that its content is aligned with skill demands in local labour markets. Moreover, the education system plays a fundamental role for preparing current and future generations for the challenges that international integration and rising digitalisation will bring about.

Key words: Brazil, trade adjustment policies, skills, education, professional training.

JEL codes: F16, F66, F68, I28

This Working Paper relates to the 2020 OECD Economic Survey of Brazil (https://oe.cd/brazil-snap )

\section{Améliorer les compétences pour tirer parti des avantages d'une économie plus ouverte au Brésil}

Le Brésil étant nettement moins intégré au commerce international que les autres économies de marché émergentes, l'ouverture au commerce a un potentiel important pour créer des emplois plus productifs et mieux payés. En même temps, cela sera associé à des changements structurels et à des coûts d'ajustement. Des travailleurs devront chercher un nouveau emploi dans des entreprises plus productives, changer de profession, de secteur ou même de lieu. En particulier, les travailleurs peu qualifiés devront améliorer leurs compétences pour accéder à des emplois nouvellement créés dans des entreprises et des secteurs en expansion. Les travailleurs qui conservent leur emploi seront confrontés à des défis similaires à mesure que les entreprises améliorent leurs processus de production vers des technologies plus avancées. Des politiques de formation et d'éducation des adultes bien conçues et bien financées, associées à des services de protection sociale et d'emploi efficaces, peuvent contribuer grandement à atténuer les coûts d'ajustement pour les travailleurs, surtout les travailleurs peu qualifiés, sans emploi et informels. Les évidences suggèrent que les politiques de formation peuvent faire une réelle différence, à condition que leur contenu corresponde aux demandes de compétences sur les marchés du travail locaux. De plus, le système éducatif joue un rôle fondamental pour préparer les générations actuelles et futures aux défis que l'intégration internationale et la numérisation croissante entraîneront.

Mots clés : Brésil, politiques d'ajustement, commerce international, compétences, éducation, formation professionnelle.

Codes JEL: F16, F66, F68, I28

Ce Document de travail a trait à l'Étude économique de l'OCDE du Brésil 2020 (https://oe.cd/brazil-snap) 


\section{Table of contents}

Improving skills to harness the benefits of a more open economy in Brazil 6

Policies can help to make trade work for all 6

Gauging the effects of stronger integration into the global economy 9

A look at local labour markets $\quad 11$

$\begin{array}{ll}\text { The reallocation of workers within sectors } & 15\end{array}$

$\begin{array}{ll}\text { The reallocation of workers across sectors } & 16\end{array}$

Targeted training can make a real difference $\quad 18$

Improving professional training policies $\quad 21$

Aligning training supply with labour market demands is key 22

Current plans draw lessons from past weaknesses, but should go further 23

Improving education policies $\quad 26$

Access to education has increased, but education quality is still weak $\quad 27$

Improving the quality of basic education $\quad 28$

Improving access to vocational education and apprenticeships 31

Improving access and quality in tertiary education 33

Annex: Additional details on the empirical analysis 35

A1. The economy-wide effects of trade liberalisation - simulations using the OECD Metro model 35

$\begin{array}{ll}\text { A1.1. The methodology } & 35\end{array}$

A1.2. Simulation results $\quad 38$

A2. Identifying the effects of trade opening on regional employment and firm dynamics $\quad 42$

A2.1. Data $\quad 42$

A2.2. Empirical methodology $\quad 45$

$\begin{array}{ll}\text { A2.3. Results } & 49\end{array}$

References $\quad 55$

\section{Tables}

Table 1. Trade liberalisation will require some workers to move to jobs in other sectors 17

Table 2. Effects of average input tariffs on economic activity 37

Table 3. Trade liberalisation will require some workers to move to jobs in other sectors 39

Table 4. Trade liberalisation will require some workers to move to jobs in other sectors 41

Table 5. Tariff reductions by percentiles of micro regions $\quad 45$

Table 6. Determinants of training provision at the micro region level 449

Table 7. Employment growth has been weaker in regions more exposed to trade liberalisation 50

Table 8. Training targeted to local skill demands mitigates adjustment costs for workers 52

Table 9. Robustness checks for the results regarding MDIC training in Table $8 \quad 53$

Table 10. Robustness checks for the results regarding other training types in Table $8 \quad 54$ 


\section{Figures}

Figure 1. The Brazilian economy has little exposure to foreign trade 6

Figure 2. Lowering trade barriers boosts productivity, exports and private consumption $\quad 7$

Figure 3. The tariff reductions of the 1990s $\quad 9$

Figure 4. The number and share of medium and high skilled jobs has strongly increased 10

Figure 5. Manufacturing employment has recovered since the 2000s 11

Figure 6. The exposure to trade liberalisation has been heterogeneous across local labour 12

Figure 7. Employment growth has been weaker in regions more exposed to trade liberalisation 14

Figure 8. Trade liberalisation has affected low-skilled workers more severely 14

Figure 9. Firm dynamics have increased in regions more exposed to trade liberalisation $\quad 15$

Figure 10. Labour productivity and real wages have risen in trade-exposed regions 16

Figure 11. Protected sectors employ many low-skilled and informal workers $\quad 19$

Figure 12. Training targeted to local skill demands mitigates adjustment costs for workers 20

Figure 13. Active labour market policies are not focused on training policies 22

Figure 14. PRONATEC courses were poorly aligned with labour market needs 23

Figure 15. Firms have difficulties to find the workers they need 26

Figure 16. Educational attainment has strongly increased $\quad 27$

Figure 17. Educational quality is weak and has not improved much $\quad 28$

Figure 18. The share of adults without completed basic education is high 30

Figure 19. Particularly old workers have low educational attainment 31

Figure 20. Opportunities for vocational training in upper secondary education are low $\quad 32$

Figure 21. Spending for tertiary education is relatively high, but dropout rates are high 33

Figure 22. Lowering trade barriers boosts productivity, exports and private consumption 40

Figure 23. Employment growth has been positive across all micro regions 51

\section{Boxes}

Box 1. Identifying the effects of trade opening on employment and firm dynamics 13

Box 2. Policy simulations based on the OECD METRO model $\quad 18$

Box 3. Training targeted to local skill demands can mitigate adjustment costs for workers 21

Box 4. Targeting vocational training to vulnerable workers 25

Box 5. Policy recommendations for improving skills $\quad 34$ 


\title{
Improving skills to harness the benefits of a more open economy in Brazil
}

\author{
By Robert Grundke, Jens Matthias Arnold, Matheus Bueno and Priscilla Fialho1
}

\section{Policies can help to make trade work for all}

With exports and imports below 30\% of GDP, Brazil's economy is significantly less integrated into international trade than other emerging market economies of similar size (Figure 1). As a result, it has foregone many of the benefits that other emerging markets have reaped from international trade and investment (OECD, 2018[1]; OECD, 2020[2]). For example, Brazilian companies have shown only scant participation in global value chains, where Brazil's only discernible link is with neighbouring Argentina (Criscuolo and Timmis, 2018[3] $)$. In Latin America, Mexico, Chile and Costa Rica exemplify how trade and the integration in global value chains can contribute to economic growth (OECD, 2017[4]).

\section{Figure 1. The Brazilian economy has little exposure to foreign trade}

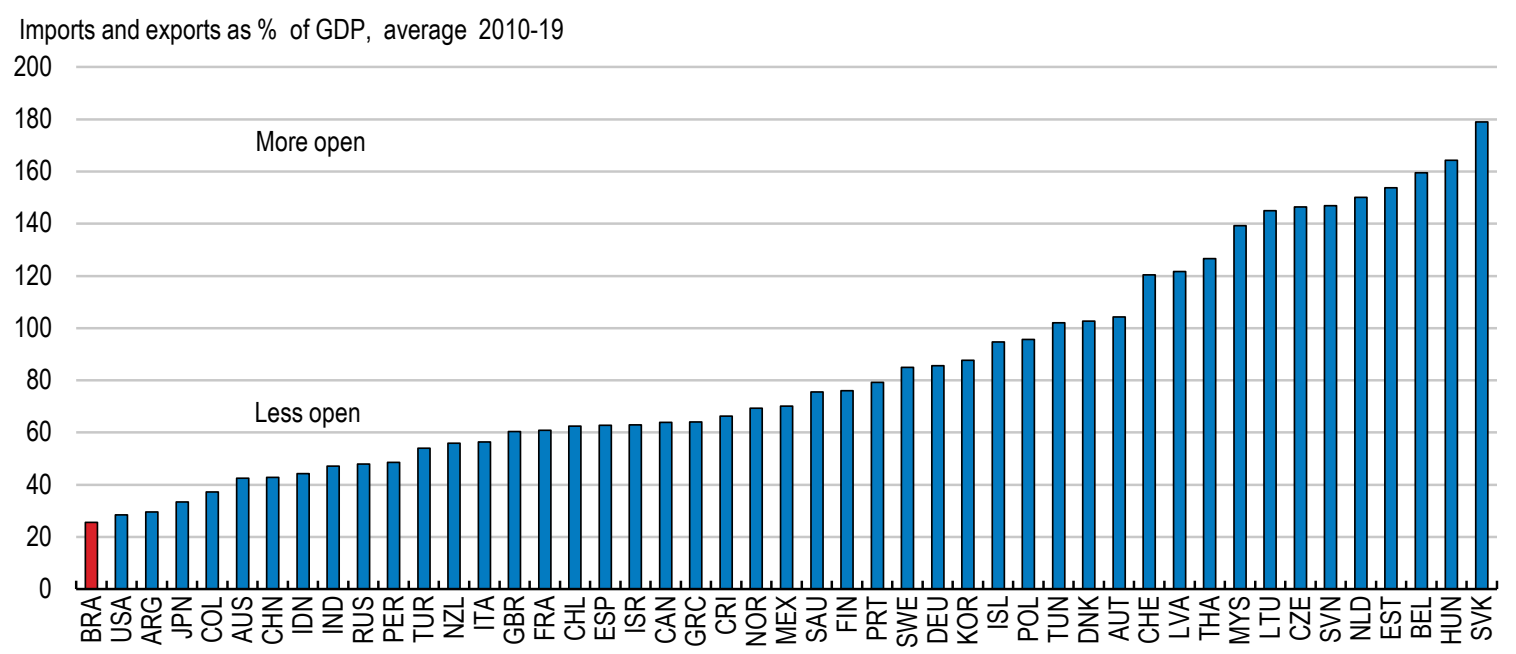

Source: OECD Economic Outlook database.

1. Acknowledgments: Jens Matthias Arnold is Senior Economist and Head of Brazil Desk in the Economics Department of the OECD. Robert Grundke and Priscilla Fialho are Economists in the same department. Matheus Bueno is Ph.D. candidate at the University of Toulouse and was consultant at the OECD while this paper was produced. Research inputs by Christine Arriola and Frank Van Tongeren of the OECD Trade Directorate are gratefully acknowledged. The authors would like to thank Alvaro Pereira, Isabell Koske, Patrick Lenain, Piritta Sorsa and Timo Leidecker for useful comments and suggestions. Special thanks are due to the Brazilian Ministry of the Economy for sharing their data with the authors. The paper has also benefited from comments by members of the OECD Economic Development Review Committee. The authors are also grateful to Anne Legendre for research assistance, and Carolina Gonzalez and Karimatou Diallo for editorial assistance. 
Fostering a stronger integration into the global economy has significant potential to raise productivity, real wages and well-being, as documented by a large and growing empirical literature. For producers, productivity and competitiveness would gain from access to cheaper and higher quality inputs and capital goods, which would in turn allow improvements in wages (Amiti and Konings, 2007[5]; Goldberg et al., $\left.2009_{[6]}\right)$. For consumers, trade has potential to reduce prices and enlarge the variety and quality of available goods, which would improve particularly the purchasing power of low-income households (Amiti, Redding and Weinstein, 2019 ${ }_{[7]}$; Grundke and Arnold, 2019 $\left.{ }_{[8]}\right)$.

Model simulations presented further down in this paper also point to significant gains for productivity and output from lower trade barriers. Simulations using the OECD Metro model suggest than an ambitious reform could raise labour productivity by $4 \%$ (Figure 2). The rising competitiveness of domestic producers would boost exports by $14 \%$, facilitating improvements in real wages. Moreover, increasing import competition would reduce consumer prices raising the purchasing power of households and private consumption by $6 \%$. These benefits are likely to be progressive as lower income households spend larger shares of their incomes on tradable goods such as food, home appliances, furniture and clothing, which are currently highly protected (Arnold and Grundke, 2021 $[9]$ ). In the case of lowering only tariff barriers, and not non-tariff measures or services trade restrictions, private consumption is estimated to rise by $4 \%$.

\section{Figure 2. Lowering trade barriers boosts productivity, exports and private consumption}

Effects of a simulated reduction of trade barriers, in percent

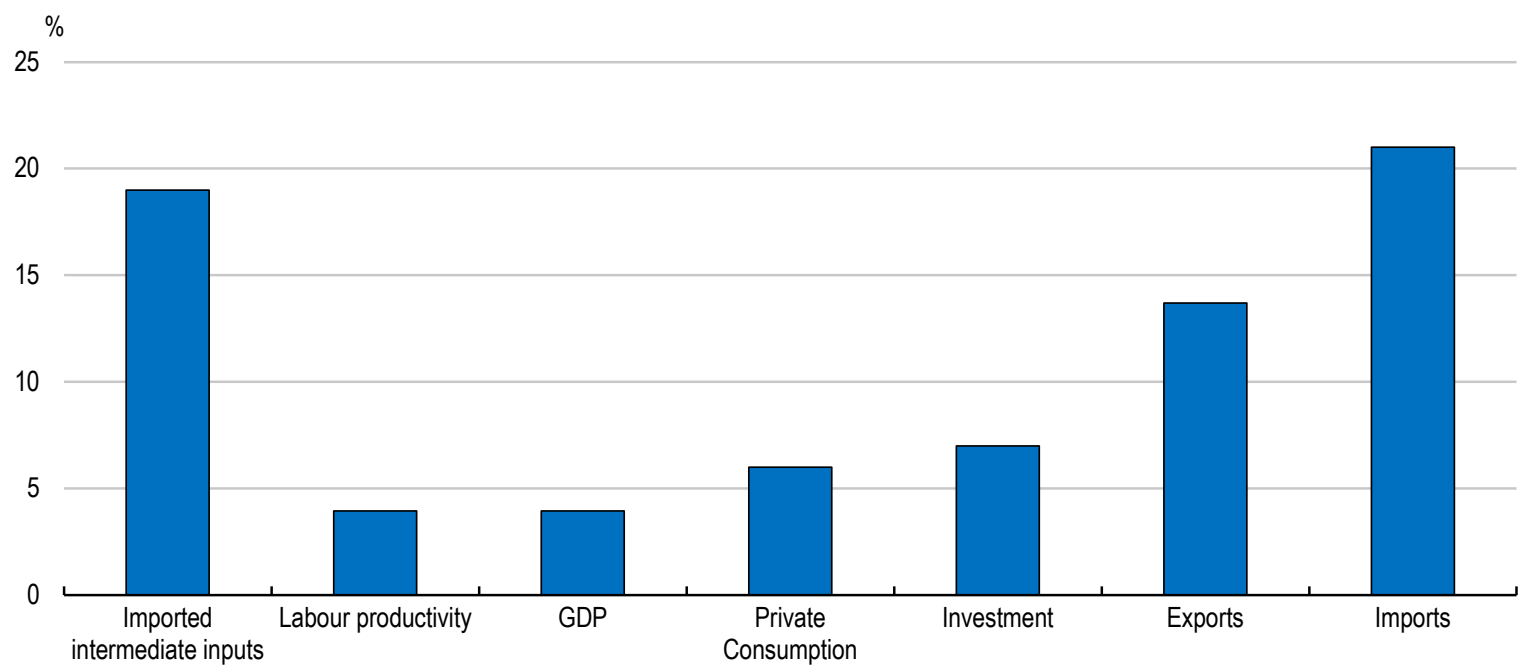

Note: Simulations are based on the OECD Metro model, a computable general equilibrium model that assumes full employment. The simulated policy change aligns tariffs and non-tariff measures unilaterally with the lowest level among G20 countries, and services trade restrictions with the G20 average. See Box 2 for a brief description of the underlying simulation analysis, and Annex A1 for further methodological details. Source: OECD calculations based on the METRO model (2020).

At the same time, opening up to trade is likely to trigger structural changes and a reallocation of resources across the economy. This reallocation across firms and sectors is a crucial element of the productivity benefits, but it can raise challenges in the transition. Increasing competitive pressures forces companies to reduce inefficiencies and upgrade their production processes through more advanced technologies. Firms need to increase product quality and reduce high prices that result from low domestic competition (Amiti and Khandelwal, 2013[10]; De Loecker et al., 2016[11]). While this benefits the more productive domestic firms, which seize newly arising export opportunities, expand and hire new workers, some low- 
productivity firms leave the market, freeing resources for the more productive firms and sectors to grow (Melitz, 2003[12]; Pavcnik, 2002[13]; Criscuolo, Gal and Menon, 2014[14]; Araújo and Paz, 2014[15]).

As workers and capital move towards more productive firms and activities, aggregate productivity increases, without necessarily triggering a massive substitution towards imports (Hsieh and Klenow, $2009_{[16]}$; Topalova and Khandelwal, 2011 [17] $)$. However, the transition of workers to other firms, sectors and locations, can imply significant adjustment costs (Winters, Mcculloch and Mckay, 2004[18]; Goldberg and Pavcnik, 2007[19]; Autor et al., 2014[20]). Displaced workers lose their wage income; they have to learn new skills and often have to bear, together with their families, the social costs of moving to other locations to find a new job (Hummels, Munch and Xiang, 2018[21]; Hyman, 2018[22]). Workers who stay in their jobs also need to update their skills. As firms upgrade production processes by employing more advanced technologies, the task content and skill requirements of existing jobs changes (Hummels et al., 2012[23]; Becker and Muendler, 2015[24]; Becker, Ekholm and Muendler, 2013[25]).

The reallocation process triggered by stronger external competition also presents opportunities for more digitalisation of production processes, which adds to potential productivity gains from rising international integration. Digitalisation will eventually amplify structural transformations in the economy (OECD, $2019_{[26]}$. Some occupations will be automated and workers will need to move to new jobs in other firms or sectors (Arntz, Gregory and Zierahn, 2016[27]; OECD, 2018[28]; Autor and Dorn, 2013[29]). In many other occupations, the nature of tasks and the skills required to perform will change (Spitz-Oener, 2006 [30]; OECD, $\left.2019_{[26]}\right]$. The digitalisation and globalisation of production processes increasingly requires a good mix of cognitive and social-interactive skills (Hummels, Munch and Xiang, 2018[21]; Grundke et al., 2018[31]).

Against this background, it is clear that embracing international trade will have distributional consequences. Empirical evidence shows that workers are affected differently by opening up to trade, depending on their skill level, occupation or the sector and firm they work in (Goldberg and Pavcnik, 2007 [19]; Winters, Mcculloch and Mckay, 2004 $\left.{ }_{[18]}\right)$. Moreover, as certain industries are concentrated in certain regions and production factors are not fully mobile across regions, trade opening can also have distributional consequences across regions (Rusticelli et al., 2018[32]).

The best policy response to these challenges is to invest in people, by supporting workers with targeted education and training programmes that address changing skill needs. Training may involve shorter vocational training courses, but also more fundamental formal education to help workers move into new occupations and sectors (Hummels et al., 2012[23]; Hyman, 2018[22]). Especially for low-skilled and informal workers, an improvement in general cognitive skills, such as literacy and numeracy, through longer term formal education courses might be necessary to participate in professional training and move into new jobs in expanding sectors and firms (Bechichi et al., 2018[33]; Bechichi et al., 2019[34]; Autor et al., 2014[20]). An effective job placement services would facilitate the transition process and support better training and employment outcomes for displaced workers (OECD, 2019[26]).

Besides education and training policies, effective social transfers and progressive taxation can also help to cushion the impact and protect people in the transition (Autor et al., 2014[20]; Lyon and Waugh, 2018[35]; Hyman, 2018[22]). The gains from embracing trade could be accelerated by policy measures to reduce frictions on labour and capital markets, improving infrastructure, especially transport infrastructure, and encouraging innovation (Rusticelli et al., 2018[32]; Fiorini, Sanfilippo and Sundaram, 2019[36]). In the case of Brazil, phasing out distortive taxes and simplifying the tax system would increase the competitiveness of domestic firms and contribute to the creation of high-quality jobs. Moreover, strengthening domestic competition on product markets would help, as Brazil still has one of the highest barriers to entrepreneurship among countries covered by the OECD Product Market Regulation (PMR) Indicators (Arnold and Grundke, 2021 $[9]$ ). Stronger domestic competition in non-tradable services inputs has the potential to strengthen productivity, and with that, competitiveness (Arnold et al., 2016[37]; Arnold, Javorcik and Mattoo, 2011[38]). 


\section{Gauging the effects of stronger integration into the global economy}

History can provide some insights into the likely effects of stronger integration going forward. Since the 1970s, trade policy in Brazil has seen only one significant inflection point, which is the visible reduction in trade barriers that occurred in the context of macroeconomic stabilisation in the 1990s. Many manufacturing sectors experienced substantial reductions in trade barriers in the early 1990s, when tariff rates fell from an average of $31 \%$ in 1990 to an average of $11 \%$ in 1995 (Figure 3). This reform had a sizeable impact on the economy, although in light of continuous trade integration around the world and the absence of significant follow-up reforms in Brazil, the economy has pretty much reclaimed its outlier position in terms of openness by now (Arnold and Grundke, 2021 [9]).

\section{Figure 3. The tariff reductions of the 1990s}

Average tariff levels by manufacturing sector in 1990 and 1995 (in \%)

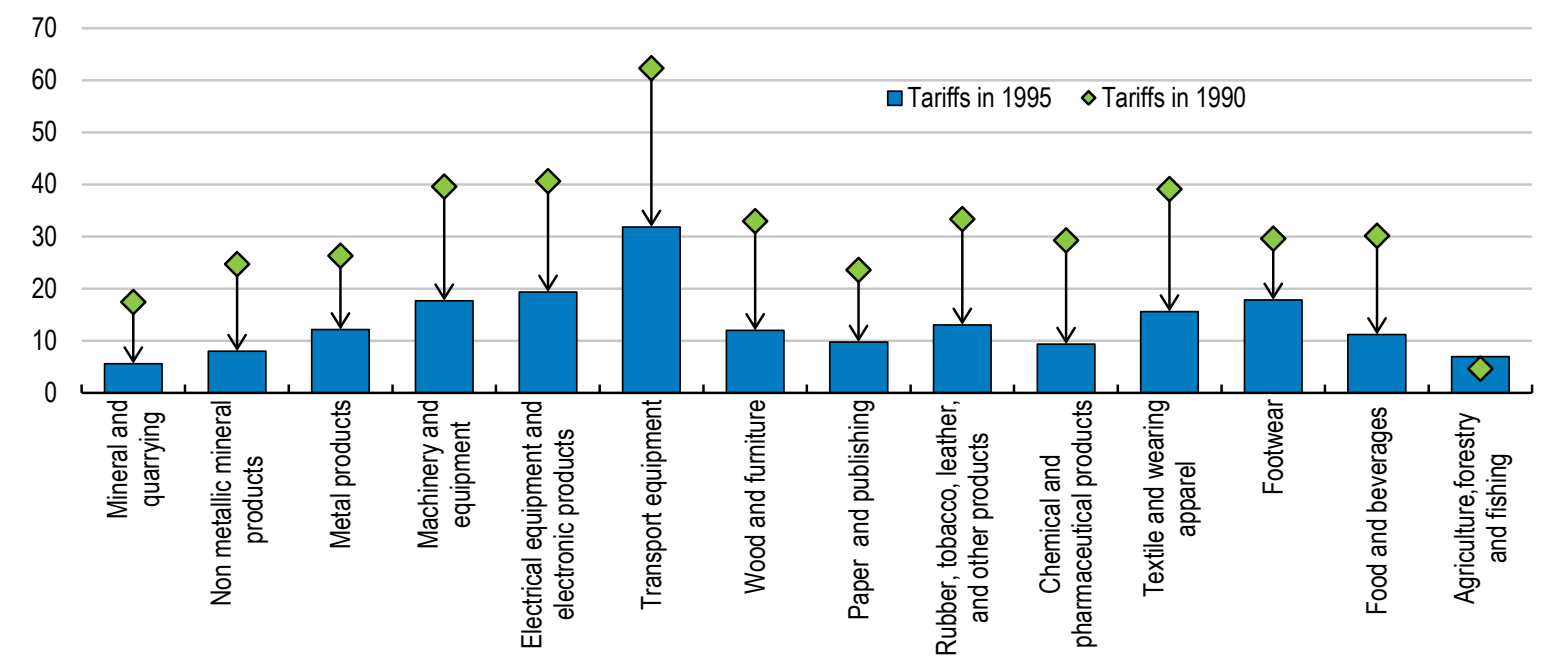

Source: Kume et al. (2003).

StatLink 제내 https://doi.org/10.1787/888934197392

Overall, the period since the 1990s has been characterised by strong growth of formal employment (Figure 4). This has been related to several factors, including improvements in macroeconomic stability, solid growth, a rising working-age population, improvements in education and progress in formalisation. In this context, the share of medium and high-skilled jobs grew steadily, reflecting both improvements in access to education and increasing demand for these skills (Silva, Almeida and Strokova, 2015[39]).

The services sectors showed a particularly strong expansion of formal employment, absorbing many young high school graduates, but also informal workers from the agricultural sector (Dutz, 2018[40]). Skill-intensive services sectors like telecommunications, information technology (IT) and other business services led this process, but also retail, transport services, and hotels and restaurants, where more skill-intensive jobs have emerged. This trend towards skilled employment in market services was complemented by a strong expansion of employment in public administration, health and education services, where over $80 \%$ of workers are medium or high skilled. 
Figure 4. The number and share of medium and high skilled jobs has strongly increased

Total formal employment and employment share by skill category
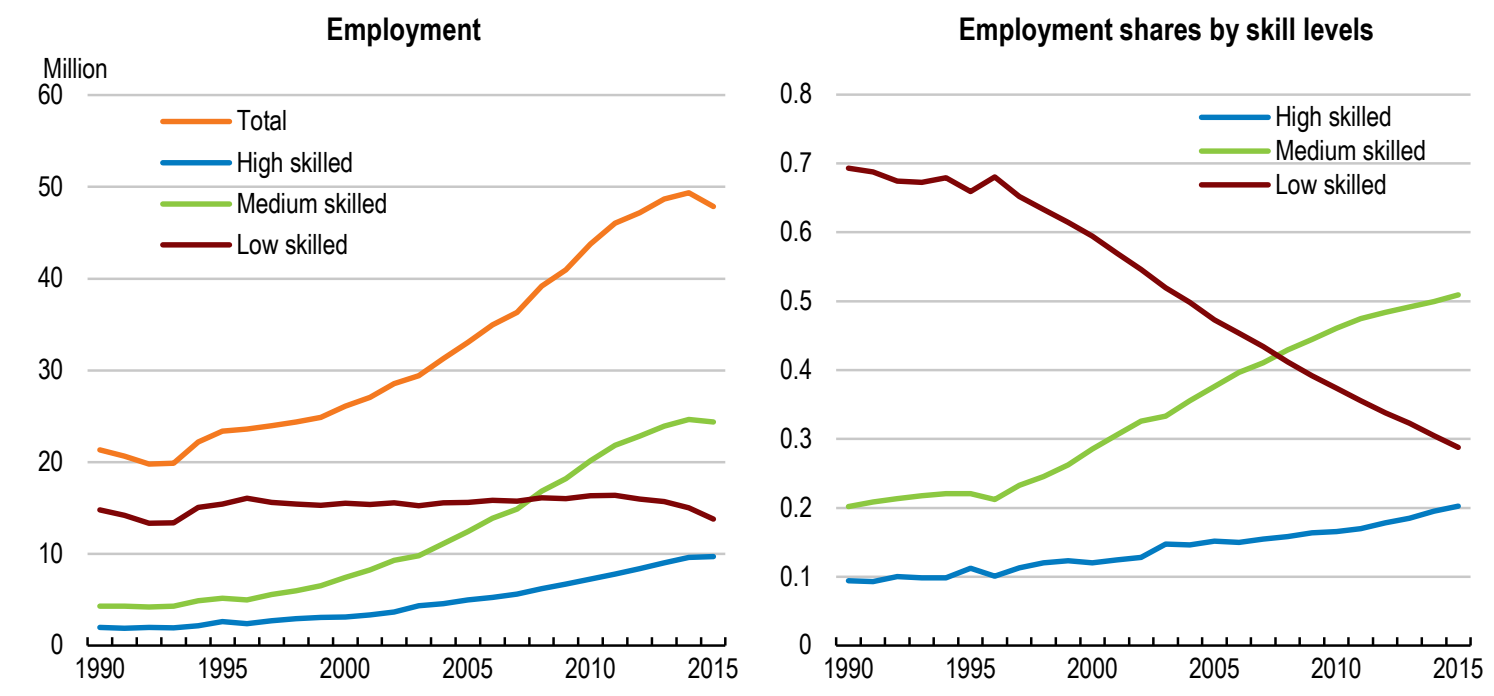

Note: Skill level is defined according to educational attainment: upper secondary not completed (low skilled), secondary completed and tertiary non-completed (medium skilled) and tertiary completed (high skilled).

Source: OECD calculations based on data from Relação Anual de Informações Sociais (RAIS).

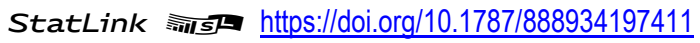

In most manufacturing sectors, falling trade barriers and the resulting rise in import competition in the early 1990s were associated with initial employment losses (Figure 5). However, over time, productivityenhancing factor reallocation and increasing exports generally lead to a strong recovery of employment, which was increasingly medium and high skilled, particularly in the chemical, machinery and transportation equipment industries (OECD calculations based on RAIS data).

For example, chemical products, food processing, machinery and equipment as well as transport equipment experienced tariff cuts of more than 20 percentage points, while labour productivity and exports grew by more than $5 \%$ and $10 \%$ per year from 1995-2011, respectively (OECD calculations based on OECD TiVA data). Formal employment initially fell but started to recover strongly towards the end of the 1990s, eventually surpassing initial employment levels. In other manufacturing sectors with sizeable tariff cuts, e.g. textile and wearing apparel, electronic equipment or rubber and plastics, productivity and export performance have been weaker. Although formal employment started to rise at the end of the 1990s, it remains below pre-liberalisation levels, the exception being the textile and wearing apparel industries, which remain highly protected. 
Figure 5. Manufacturing employment has recovered since the 2000 s

Cumulative net job creation since 1990 as a share of employment (by manufacturing sector)

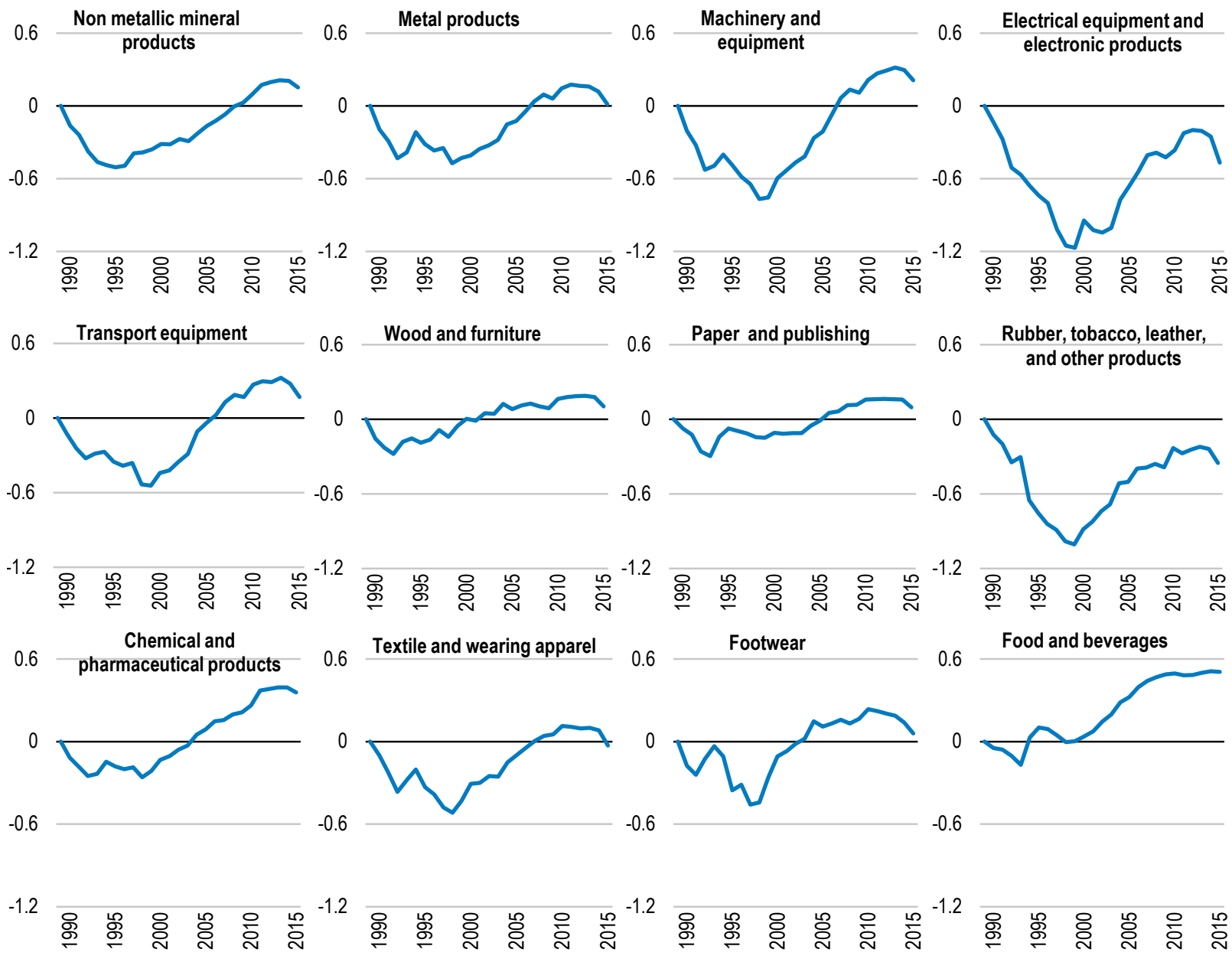

Note: The figures shows the cumulative net job creation since 1990 divided by total employment in each year. Source: OECD calculations based on RAIS data.

StatLink त्ताज्य https://doi.org/10.1787/888934197430

\section{A look at local labour markets}

Drawing lessons from aggregate or even sector-specific developments is intrinsically difficult due to a myriad of competing explanations and factors acting at these levels. For this reason, an empirical analysis based on 481 local labour markets can provide more reliable insights into the effects of increasing international economic integration on employment and firm dynamics in Brazil. Local labour markets, called micro regions in Brazilian national statistics, differ with respect to their industry structure and thus their exposure to trade liberalisation (Figure 6). This in turn allows identifying the effects of trade opening by focusing on different trajectories of outcomes across regions (Box 1). 
Figure 6. The exposure to trade liberalisation has been heterogeneous across local labour

Tariff reductions 1990-1995 weighted by industry employment shares in micro regions (in percentage points)

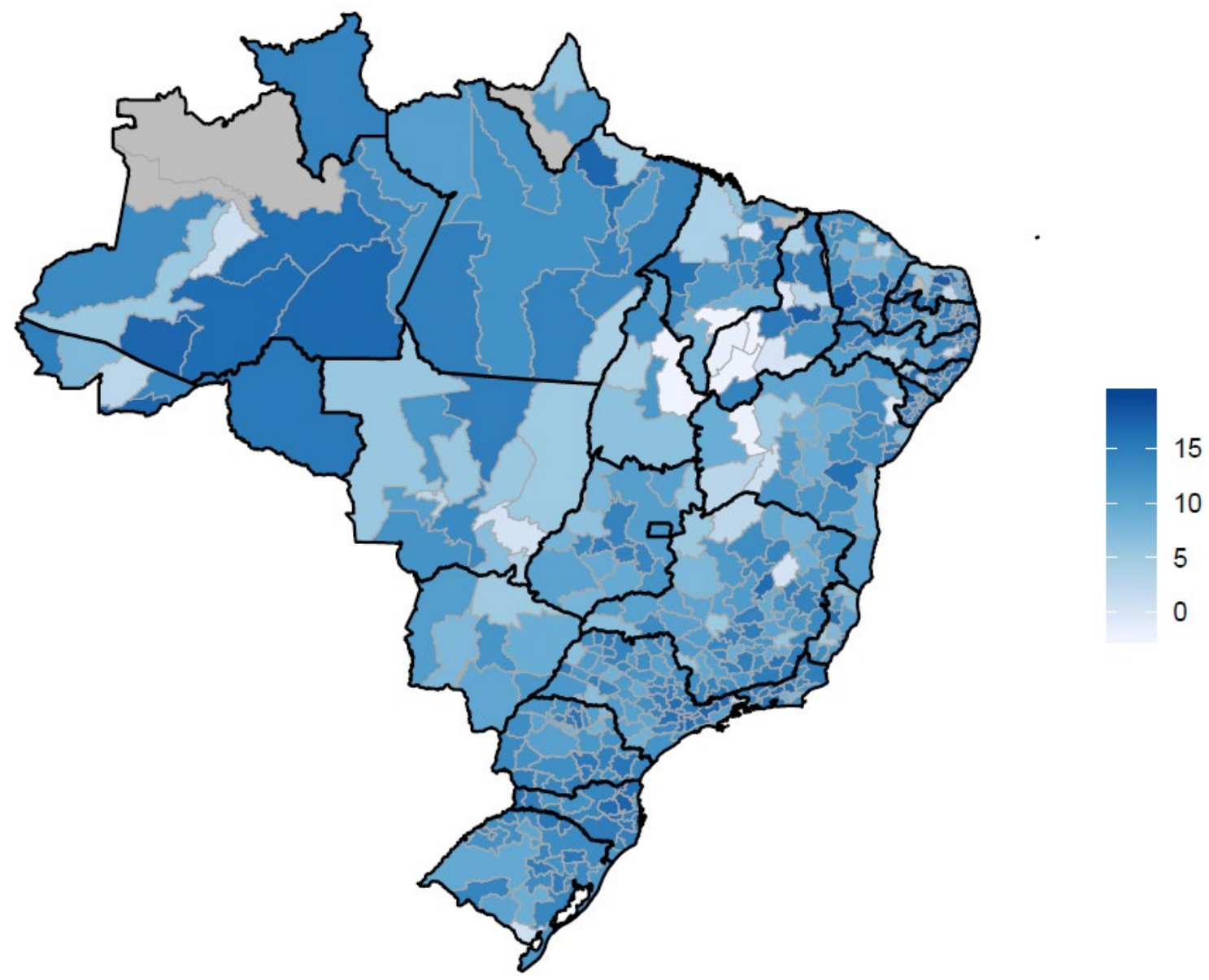

Note: Micro regions are defined by the Brazilian national statistics institute as an aggregation of municipalities that are well connected by transport infrastructure. Regional trade exposure is computed as the weighted average of tariff cuts from 1990-1995, with industry employment shares per micro region as weights.

Source: OECD calculations based on RAIS data and data from Kume et al. (2003).

Although formal employment has increased strongly since the 1990s, employment growth has generally been weaker in regions that were more exposed to import competition (Figure 7). To some extent, this reflects initial employment losses in manufacturing sectors during the 1990s. Since the 2000s, formal employment has recovered, but some differences between regions with different levels of exposure to trade liberalisation remain. For example, a micro region that experienced a 10 percentage point larger tariff cut in the 1990s, approximately the difference in tariff reductions between the $90^{\text {th }}$ and the $10^{\text {th }}$ percentile of micro regions, showed a 45 percentage point lower employment growth between 1990 and 2015. These average effects hide considerable heterogeneity across micro regions that have experienced large tariff cuts in the 1990s. Some of them have performed well, with strong employment and output gains recorded in micro regions located in poorer states such as Pernambuco, Maranhão, Alagoas and Rio Grande do Norte (OECD analysis). 


\section{Box 1. Identifying the effects of trade opening on employment and firm dynamics}

\section{The trade liberalisation of the 1990s and local labour markets in Brazil}

After four decades of policies to foster industrialisation through import substitution including high import protection, Brazil lowered import tariffs significantly from 1990 until 1995 (Figure 3). This policy change was unexpected, as a polarised political landscape and close presidential elections in 1989 had led to high uncertainty about the future course of economic policy (Cavgias et al., 2019 ${ }_{[41]}$ ). Immediately after taking office in early 1990, the new president announced a schedule to reduce tariffs until 1995, mostly implemented ahead of the initially set dates. The size of tariff reductions by sector was mostly determined by pre-liberalisation tariff levels, as the objective was to lower and equalise import protection across sectors to reduce distortions of relative prices (Dix-Carneiro and Kovak, 2017[42]).

The fact that during the 1990s a range of different macroeconomic and structural policies were implemented simultaneously makes it difficult to draw conclusions from macro-economic or sectoral data. One frequently applied solution to this identification problem is the local labour market approach (Autor, Dorn and Hanson, 2013[43]; Topalova, 2010 [44]; Dix-Carneiro and Kovak, 2017[42]). Local labour markets differ with respect to their industry structure and thus their exposure to trade liberalisation (Figure 6), but are subject to the same national institutions and macroeconomic shocks. Together with the fact that migration of workers and firms between local labour markets is costly, it is possible to disentangle the effects of trade opening on employment and firm dynamics by focusing on different trajectories across regions. The analysis exploits differences across micro regions as defined by the Brazilian statistics institute (IBGE), which combine municipalities that are well connected by transport infrastructure and have common production structures (Dix-Carneiro and Kovak, 2017 ${ }_{[42]}$ ).

The analysis follows the empirical literature investigating how trade affects local labour markets and constructs a regional measure of exposure to tariff reductions, using regional employment by industry as weights (Topalova, 2010[44]; Dix-Carneiro and Kovak, 2017[42]). This is combined with administrative labour market data covering the universe of formal sector workers and firms from 1985-2015 including information on employment, wages and other socio-economic characteristic of workers. The analysis uses a long-difference estimator to investigate the effects of trade exposure on regional firm dynamics and labour market outcomes across time (Dix-Carneiro and Kovak, 2017 $[42]$. Further details on the empirical methodology are described in Annex A2.

Employment growth in regions that were more exposed to trade liberalisation has been especially weak for low-skilled workers. From 1990 until 2015, their employment share has decreased by 3.7 percentage points relative to less exposed regions (Figure 8). Particularly the share of medium-skilled jobs has increased in trade-exposed regions, but high-skilled employment has also expanded its relative weight. A similar trend can be observed for real wages as well as wage shares across skill groups. From 1990 until 2015 , the wage share of low skilled workers in trade-exposed regions decreased by 7.2 percentage points relative to less exposed regions, and the one of medium and high-skilled workers increased by 4.2 and 3 percentage points, respectively. This indicates that rising import competition presents challenges for lowskilled workers, who need to move to newly created medium-skilled jobs in expanding firms and sectors, or even other regions.

Identifying sectors, firms, occupations and regions, where workers will be displaced or new jobs will be created, is key to design efficient and effective training policies and mitigate adjustment costs for workers. The content and intensity of the required training depends on the difference between the task-specific skill requirements in the old and the potential new job as well as the general cognitive and social skills of the worker (Bechichi et al., 2018[33]). Especially for older workers, learning new skills and moving to new jobs in other firms, sectors or regions can be costly (Autor et al., 2014[20]). 
Figure 7. Employment growth has been weaker in regions more exposed to trade liberalisation Differences in employment growth between regions more and less exposed to trade opening

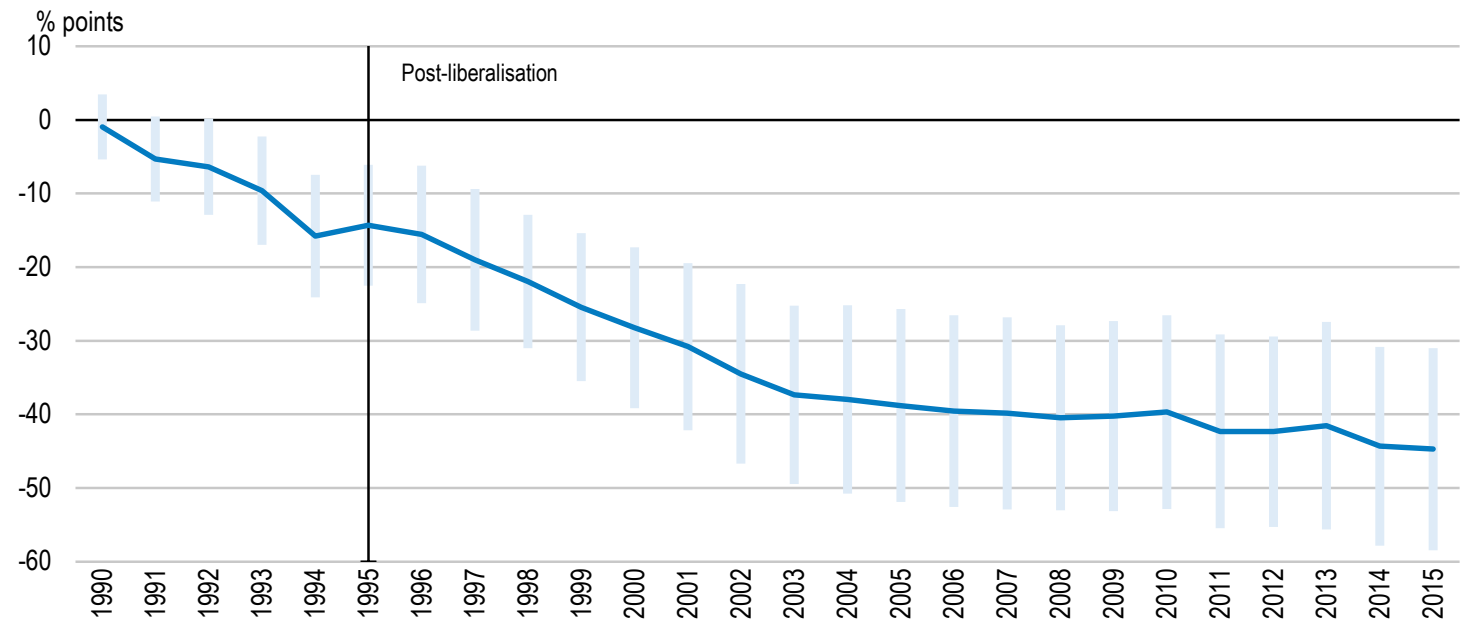

Note: Trade-exposed regions are defined as micro regions that experienced a 10 percentage points larger tariff cut in the 1990s (approximately the difference in tariff reductions between the $90^{\text {th }}$ and the $10^{\text {th }}$ percentile of micro regions). The bars show $95 \%$ confidence bands.

Source: OECD calculations based on RAIS data.

StatLink त्ञात् https://doi.org/10.1787/888934197449

Figure 8. Trade liberalisation has affected low-skilled workers more severely

Differences between more and less trade-exposed regions by skill level

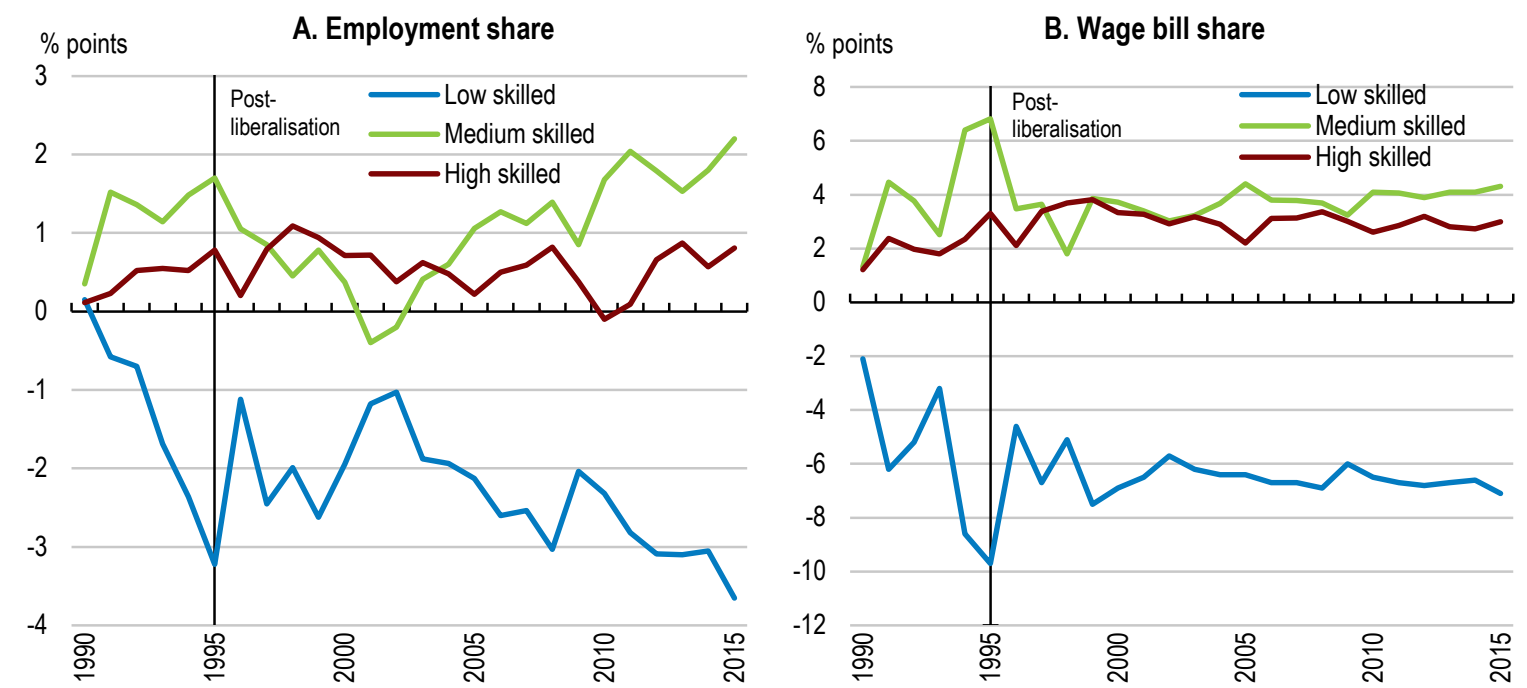

Note: Trade-exposed regions are defined as micro regions that experienced a 10 percentage points larger tariff cut in the 1990s (approximately the difference in tariff reductions between the 90th and the 10th percentile of micro regions). Employment share by skill level represents the number of workers by skill level (per micro region) divided by the total number of workers (per micro region). Wage bill share by skill level represents the wage bill of workers by skill level (per micro region) divided by the total wage bill (per micro region). Source: OECD calculations based on RAIS data. 


\section{The reallocation of workers within sectors}

Training needs depend on the exact nature of reallocation. As producing the same type of products usually requires a similar set of skills, the need for training to help displaced workers move to other firms in the same sector is likely to be smaller than for moves to other sectors (Bechichi et al., 2018[33]; OECD, 2019[26]). Nevertheless, firms within the same sector differ in their production processes and the type of technology they use (Andrews, Criscuolo and Gal, 2015[45]). Increasing technology adoption among highly productive frontier firms will change the task-content of occupations and require workers who move to more productive firms to update their skills (Bechichi et al., 2019[34]; Hummels et al., 2012[23]; Hummels, Munch and Xiang, 2018[21]).

Rising import competition has invigorated the forces of creative destruction and increased entry and exit rates of firms. This churning process has been more pronounced in regions more exposed to trade liberalisation, where cumulative firm entry and exit rates exceeded those of less exposed regions by 7 and 11 percentage points in 2015, respectively (Figure 9). Resources shifted from exiting to entering firms, as the average size of incumbents has decreased and the size of entrants increased in more trade-exposed regions.

\section{Figure 9. Firm dynamics have increased in regions more exposed to trade liberalisation}

Differences between more and less trade-exposed regions

\section{A. Cumulative entry and exit rates}

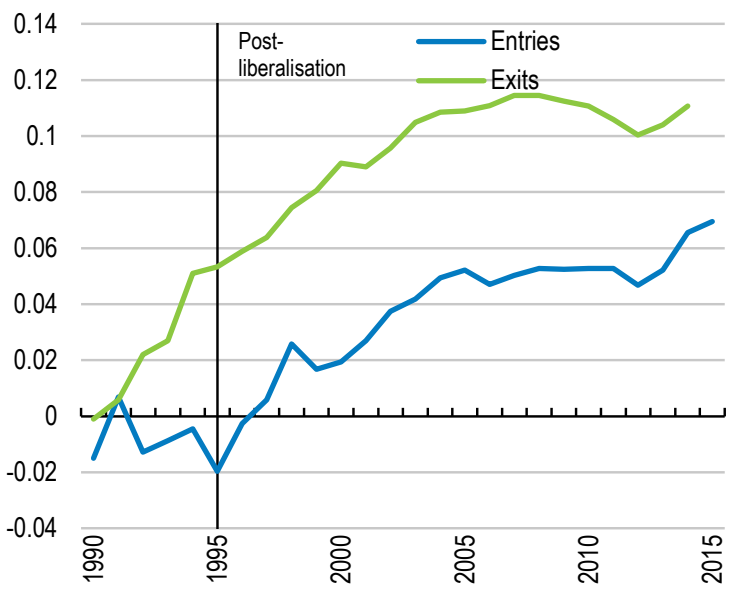

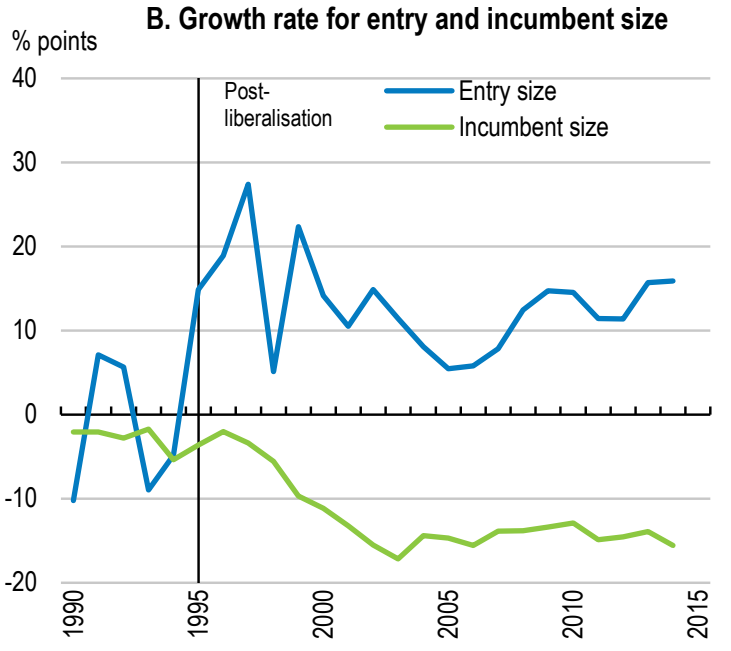

Note: Trade-exposed regions are defined as micro regions that experienced a 10 percentage points larger tariff cut in the 1990s (approximately the difference in tariff reductions between the 90 th and the 10 th percentile of micro regions). Cumulative entry and exit rates represent cumulative sums of entering and exiting plants by micro region since 1990, respectively, divided by the total number of plants per micro region in each year. The average size of entering and incumbent plants per micro region are measured using formal employees per plant.

Source: OECD calculations based on RAIS data.

StatLink त्ञाs https://doi.org/10.1787/888934197487

Higher churning has in turn led to increases in productivity and real wages. Labour productivity has risen more rapidly in trade exposed regions, supporting exports and enabling increases in real wages (Figure 10). In particular, real wages for medium and high skilled workers have grown faster in tradeexposed regions, signalling that the upgrade of production processes and technology adoption in more productive firms are complementary to high and medium-skilled labour. 
Figure 10. Labour productivity and real wages have risen in trade-exposed regions

Differences between more and less trade-exposed regions

A. Growth of GDP per worker

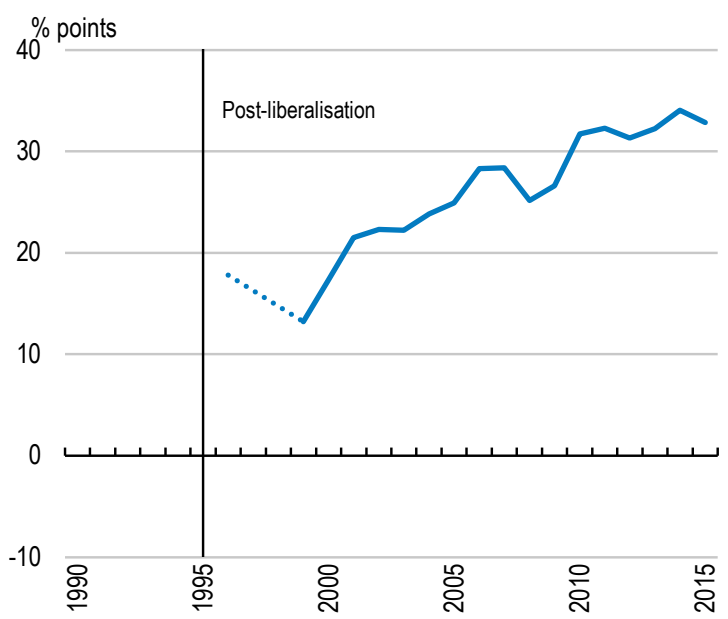

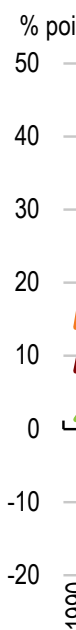

B. Real wage growth by skill level

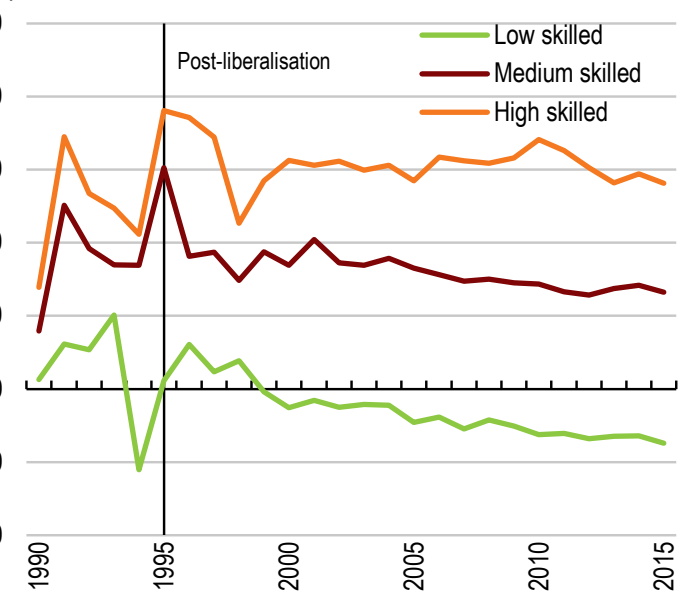

Note: Trade-exposed regions are defined as micro regions that experienced a 10 percentage points larger tariff cut in the 1990s (approximately the difference in tariff reductions between the 90 th and the 10th percentile of micro regions). Average labour productivity per micro region is measured as GDP divided by the number of formal sector workers. As GDP data for micro region is not available for all years, differences in labour productivity growth between regions are computed using 1985 as the base year and the regressions start in 1996.

Source: OECD calculations based on RAIS data and GDP data by municipality from IBGE.

StatLink त्ञाs https://doi.org/10.1787/888934197506

The finding that lower trade barriers foster the creation of medium-skilled jobs presents an opportunity for training and education policies to succeed in mitigating the adjustment costs for low-skilled workers. Many of these medium-skilled jobs that have expanded in regions more exposed to trade liberalisation are lowcomplexity white-collar jobs, such as clerical support, services and sales workers. Transitions from lowskilled occupations to these expanding medium-skilled occupations may imply relatively manageable training needs (Bechichi et al., 2018[33]).

As rising trade exposure increases job-turn over particularly for low and medium skilled workers, the transition towards a more open economy would be easier with additional policy support for these workers. This could take the form of strengthening the social safety net, especially for informal workers, and skills programmes, to reduce the length of unemployment spells.

\section{The reallocation of workers across sectors}

The current structure of import protection varies considerably across different sectors of the economy. Tariff rates are high for textile, wearing apparel, leather and furniture industries, and non-tariff measures particularly protect food processing, transport equipment as well as machinery and equipment industries (Cadot, Gourdon and van Tongeren, 2018[46]). Services sectors also differ in their openness to foreign competition, with banking, insurance, media and broadcasting as well as logistics showing the highest barriers to foreign entry (OECD calculations based on the STRI index).

Lowering these trade barriers will lead to reallocation of labour across sectors with substantially different skill-requirements (Bechichi et al., 2019 [34]). Identifying existing sectors with particularly strong challenges and large expected training needs can help to target training and education policies effectively. At the same time, identifying those sectors with particularly strong future employment potential may help to guide the choice of training content. 
Economic models can help to guide these choices. Static computable general equilibrium models are a common analytical tool to investigate the effects of trade liberalisation on the reallocation of production factors across sectors, while assuming that total factor endowments in the economy are fixed (Box 2). The modelling exercise presented in the introduction of this paper and further elaborated in Annex $A 1$, based on the OECD METRO model, is meant to shed more light on this issue.

Some manufacturing sectors with high protection, such as textile and wearing apparel, metal products, machinery and equipment, motor vehicles, electronic equipment and other manufacturing, would face stronger import competition with lower trade barriers. Rising competitive pressures will increase productivity and ultimately lead to rising production and exports in those sectors. However, the model simulations suggest some employment losses in highly protected sectors (Table 1). The same holds for a number of services industries like finance, business services or transport services, where moderate reductions in the workforce would go along with rising productivity, output and exports. At the same time, the model simulation also identifies sectors where new employment opportunities will arise. These include food processing, agriculture, transport equipment, communication services and other services sectors such as utilities, retail, construction, tourism, education and health.

Table 1. Trade liberalisation will require some workers to move to jobs in other sectors

Effects of a simulated reduction of tariff and non-tariff protection as well as services trade restrictions

\begin{tabular}{l|l|l}
\hline & \multicolumn{1}{|c}{$\begin{array}{c}\text { Changes in employment due to trade } \\
\text { liberalisation scenario from METRO model (in \%) }\end{array}$} & \multicolumn{1}{c}{ Formal and informal employment per sector in } \\
\hline Cereal grains & 2.0 & 502 \\
\hline Other agriculture & 1.3 & 5490 \\
\hline Oil seeds & 2.4 & 22 \\
\hline Dairy & 0.1 & 220 \\
\hline Natural resources & 2.0 & 440 \\
\hline Meats & 3.7 & 3023 \\
\hline Food and beverage & 0.4 & 1067 \\
\hline Textile and wearing apparel & -4.9 & 2751 \\
\hline Mineral products & -2.8 & 553 \\
\hline Ferrous metals & -3.5 & 154 \\
\hline Nonferrous metals & 1.7 & 66 \\
\hline Metal products & -5.1 & 954 \\
\hline Motor vehicles and parts & -4.7 & 476 \\
\hline Transport equipment & 23.3 & 113 \\
\hline Electronic equipment & -5.2 & 359 \\
\hline Machinery and equipment & -10.6 & 521 \\
\hline Other manufacturing & -4.4 & 2836 \\
\hline Transportation & -0.6 & 4680 \\
\hline Communication & 0.6 & 1244 \\
\hline Financial services & -0.8 & 906 \\
\hline Insurance & 0.1 & 357 \\
\hline Business services & -2.1 & 7129 \\
\hline Other services & 0.5 & 58468 \\
\hline Total & 0 & 92331 \\
\hline Note: The simulan & & \\
\hline
\end{tabular}

Note: The simulation reduces tariffs and ad-valorem equivalents for non-tariff measures unilaterally to the lowest level among G20 countries, and services trade restrictions to the average level across $\mathrm{G} 20$ countries. Total employment in the METRO model is fixed and includes formal and informal workers as defined by the International Labour Organisation.

Source: OECD calculations based on the METRO model (2020). PNAD 2018. 


\section{Box 2. Policy simulations based on the OECD METRO model}

The effects of trade policy changes tend to affect almost all parameters of an economy due to numerous feedback effects. One attempt to capture these effects is to undertake simulations in a computable general equilibrium model, which combines the supply and the demand sides of an economy. Such models can capture the input linkages between economic sectors and model the markets for production factors, which are mobile across sectors. Thus, tariff changes affecting output in one sector also have repercussions on other sectors by changing the demand and the equilibrium prices for inputs and production factors. General equilibrium models also capture the feedback effects of changing income of workers and relative prices of goods and services on private consumption, as well as the interlinkages of disaggregated sectoral trade flows.

To analyse the economy-wide effects of a reduction in import protection for Brazil, simulations have been undertaken using the OECD METRO model, which links 61 countries and 57 economic sectors (see Annex A1). This static model assumes fixed endowments and full employment of production factors and has been used widely in trade analysis to simulate the effects of domestic trade policy reforms in an international environment (OECD, 2015[47]). The model simulations incorporate a productivity-enhancing effect of improving access to and lowering prices of foreign inputs, based on the estimated elasticity of labour productivity with respect to input tariffs. This has been obtained from panel data covering 33 sectors across the period1995-2011. The final model has been used to simulate a unilateral decrease of Brazil's currently applied tariffs and non-tariff measures to the lowest levels among G20 countries as well as its services trade restrictions to the average level among G20 countries.

\section{Targeted training can make a real difference}

The results of the econometric analysis and the modelling exercise can provide inputs for the targeting and the content of future training programmes. Training needs will depend on the difference between the taskspecific skill requirements in the old and the potential new job, but also on the general cognitive and social skills of the worker (Bechichi et al., 2018[33]). Many workers in protected sectors have not completed primary education and are in informal employment, lacking access to formal training opportunities (Figure 11). For these workers, improvements in general cognitive skills through longer-term formal education courses are a pre-condition for bridging the skill gap towards newly created medium-skilled jobs in expanding firms or sectors (Bechichi et al., 2018[33]).

In particular, workers in the heavily protected textile and wearing apparel industries will require intensive education courses to prepare for future job transitions. More than $31 \%$ of the workforce of 2.8 million have not completed primary education and $44 \%$ are in informal employment (Figure 11). Metal products and other manufacturing industries show a similar picture. In agriculture, food processing and some services sectors, which are expected to expand employment as import barriers fall, the share of low skilled and informal workers is also very high (Figure 11). As these sectors face rising import competition and jobs move towards high-productivity firms, basic adult education policies are key to prepare these workers for the challenges associated with new technologies and rising product quality. 
Figure 11. Protected sectors employ many low-skilled and informal workers

The share of workers without completed primary education and the share of informal workers (by sector)

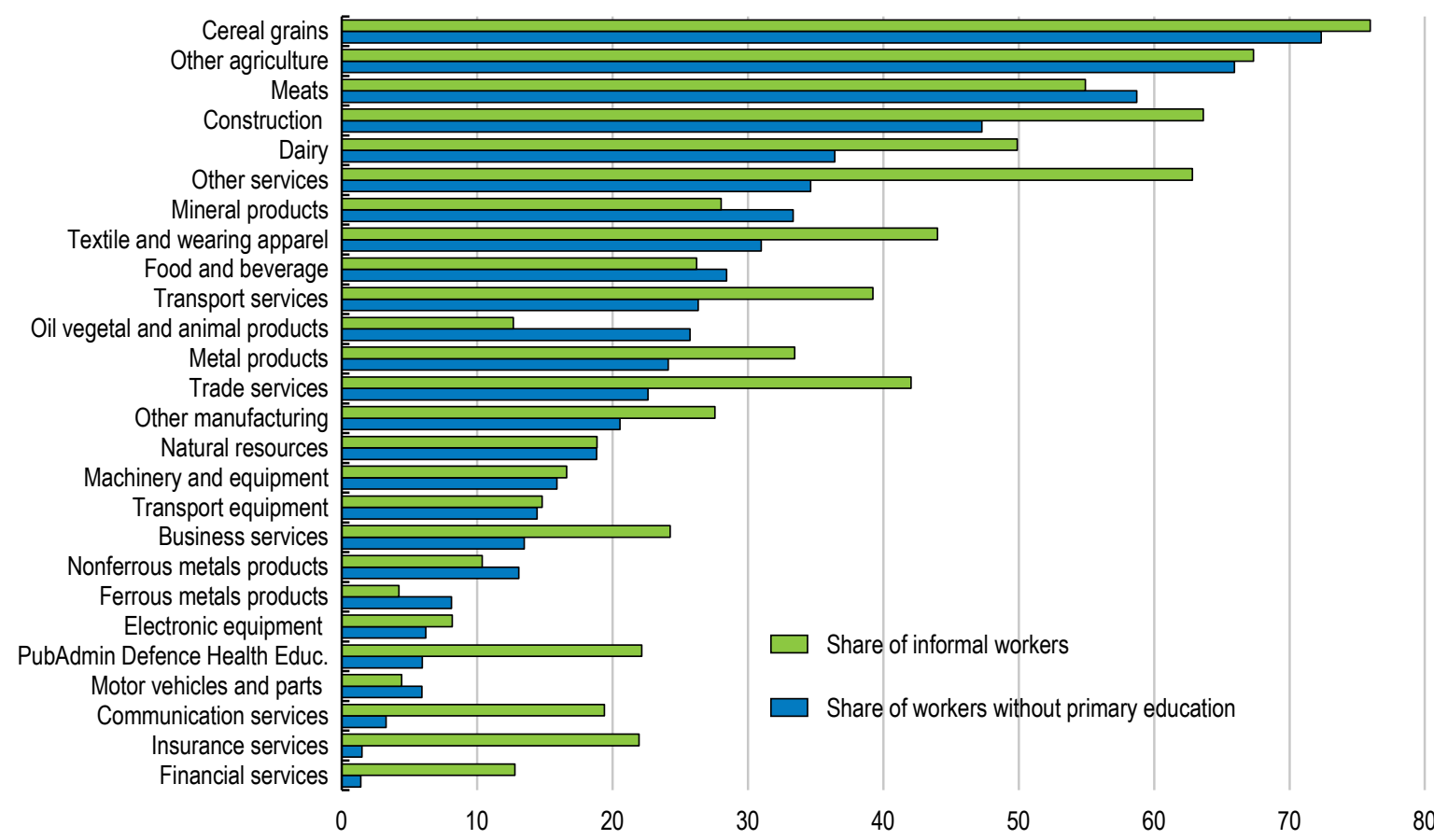

Source: PNAD 2018.

StatLink ज्ञाs https://doi.org/10.1787/888934197525

Moreover, displaced workers who dispose of the necessary cognitive skills for moving into medium and high skilled jobs may need more specific vocational training courses to acquire the specific skills necessary for a new job. For these courses to be successful, alignment with skill demands in local labour markets is key. This implies a need to involve the private sector closely in content, design and implementation of these courses (O'Connell et al., 2017[48]; OECD, 2018 $\left.{ }_{[49]}\right)$. The geographic mobility of workers, and in particular of low-skilled and older workers, is often severely limited by the low quality of transport infrastructure, housing market distortions, job search costs, social costs of moving families or a limited ability to learn and adapt to new social contexts (Autor et al., 2014[20]; Gathmann, Helm and Schönberg, 2018[50]; Hyman, 2018[22]). A lack of alignment with local labour market needs has been identified as a shortcoming of previous training programmes, notably the large-scale programme PRONATEC (OECD, 2018[51]]). For example, poorly designed remuneration incentives have led training suppliers to build up excessive training capacities for secretarial assistants, which were relatively cheap to instruct, while local companies continued to face severe difficulties in hiring staff with technical skills.

Empirical analysis based on micro data allows matching regional exposure to stronger import competition with detailed information on past training policies (Box 3). In particular, this information allows the identification of training capacity that was created in response to skill demands by local employers, which corresponds to a small fraction. The results of this analysis suggest that only this vocational training that was aligned with local skill demand has been effective to reduce the negative employment effects of rising import competition (Figure 12). Trade-affected micro regions that have raised the supply of vocational training courses targeted to local skill demands by an average of 10,000 training class hours from 2011 to 2015 have narrowed the gap in employment growth with respect to less trade-exposed regions by around 
$50 \%$. Other types of training courses, which had not specifically targeted skill demands in local labour markets, have had much smaller effects on employment growth. In many cases, the effects were negligible, highlighting the importance of targeting.

\section{Figure 12. Training targeted to local skill demands mitigates adjustment costs for workers}

Differences between more and less trade-exposed regions

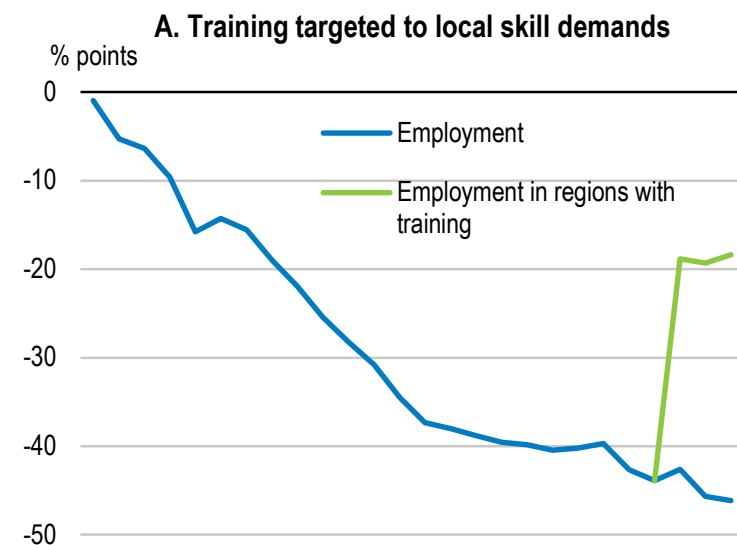

$-60$

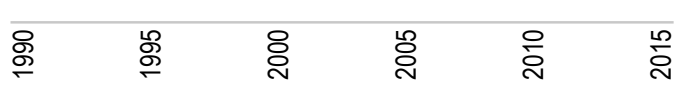

B. Training not targeted to local skill demands

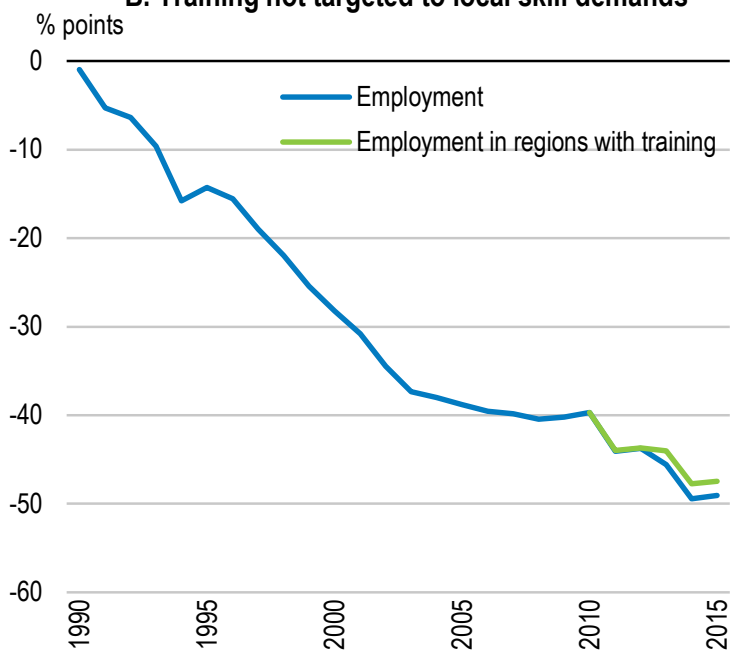

Note: Trade-exposed regions are defined as micro regions that experienced a 10 percentage points larger tariff cut in the 1990s (approximately the difference in tariff reductions between the 90th and the 10th percentile of micro regions). Regions with training are micro regions that have increased training class supply by 10,000 hours from 2011-2015.

Source: OECD calculations based on RAIS data.

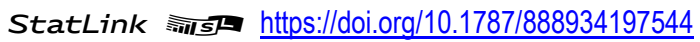

One lesson that can be distilled from this analysis is that the investment required to implement effective training programs is manageable and likely to have high pay-offs, once proper targeting is ensured. OECD estimates based on micro-data and past training costs suggest that additional yearly spending in the order of $0.5 \%$ of GDP could be sufficient to address upcoming skill challenges, provided that future training programmes are carefully targeted to skill demands in local labour markets.

However, for the 24 million workers without completed primary education, the necessary investments are likely to be higher. Vocational training courses targeted to local skill demands have particularly improved employment opportunities for medium-skilled workers (Blyde et al., 2019 [52]; O'Connell et al., 2017[53])This may be a sign that current training institutions have not been successful in supporting workers who need it the most. Completing basic adult education is a pre-condition for successfully attending many vocational training courses. Thus, policies to prepare the workforce for the rising integration into the global economy need to comprise an ambitious expansion of adult education and an improvement of its quality. 


\section{Box 3. Training targeted to local skill demands can mitigate adjustment costs for workers}

To investigate how training can mitigate adjustment costs for workers, empirical analysis undertaken in this paper combines administrative labour market data with micro data on training enrolment and completion from Brazils PRONATEC programme from 2011-2015. PRONATEC was a government-led initiative that strongly expanded the offer of short-term vocational training courses to low-skilled workers and unemployed individuals. The Ministry of Education coordinated the programme, but other ministries could request training courses for specific localities and select training participants (OECD, 2018[51]). There were no guidelines to collaborating ministries on how to identify training needs in their respective areas of intervention. Most ministries organised their requests centrally without consulting regional and local authorities. This resulted in many courses not meeting the skills required by recruiting firms in local labour markets and not addressing individuals' actual re-skilling needs (O'Connell et al., 2017[48]; OECD, 2018[51]).

The Ministry of Industry (MDIC) was the only PRONATEC partner that developed a systematic method to assess and anticipate skills needs before submitting course requests. Their method explicitly took into account the location, scale and skill content of firms training needs, and training classes started in 2013. Initially, staff at MDIC contacted firms in different sectors and locations informally to enquire about their training needs. At a later stage, MDIC developed a web platform called "SuperTec" where employers could register and provide information regarding their skills needs and the volume of training desired. The platform significantly increased the efficiency of the information collection procedure. As a result, training courses demanded by MDIC were demand-driven, as opposed to the courses from other collaborating ministries (O'Connell et al., 2017[53]; OECD, 2018[51]).

The empirical analysis uses data on training courses at the micro region level and separates between courses offered by MDIC and courses offered by other Ministries to single out training that targeted local skill demands. Further information can be found in Annex A2.

\section{Improving professional training policies}

The empirical analysis based on the 1990s trade reforms shows a need for training policies to accompany future trade opening, to ensure that all Brazilians can reap the benefits, including those with low skills. At the same time, the analysis also shows how much of an impact training policies can have to mitigate challenges in the transition, provided that they are well-designed. This combination builds a strong case for a major boost to investing into people, by providing them with the necessary skills to reap new opportunities. Investing in people's skills will not only help to master the transition towards a more modern and open economy, but it will also support the productivity improvements that Brazil urgently needs to sustain economic growth (Arnold and Grundke, 2021 ${ }_{[9]}$ ).

Within the realm of active labour market policies, Brazil's expenditure is on par with the OECD average, but this spending is much less concentrated on training policies (Figure 13). Most of the spending goes to programmes supporting self-employment and micro enterprise creation as well as to employment subsidies. Part of these resources could be shifted to vocational training and adult learning policies, as these other measures are less effective in increasing the employability of participants (Brown and Koettl, 2012[54]). In addition, improving labour market job services and linking them better with training policies may also require additional resources, but can significantly improve the employability of job seekers and reduce skill-mismatch in the labour market (OECD, 2018[51]). 
Figure 13. Active labour market policies are not focused on training policies

Public expenditure on training-based and total active labour market policies (in \%)

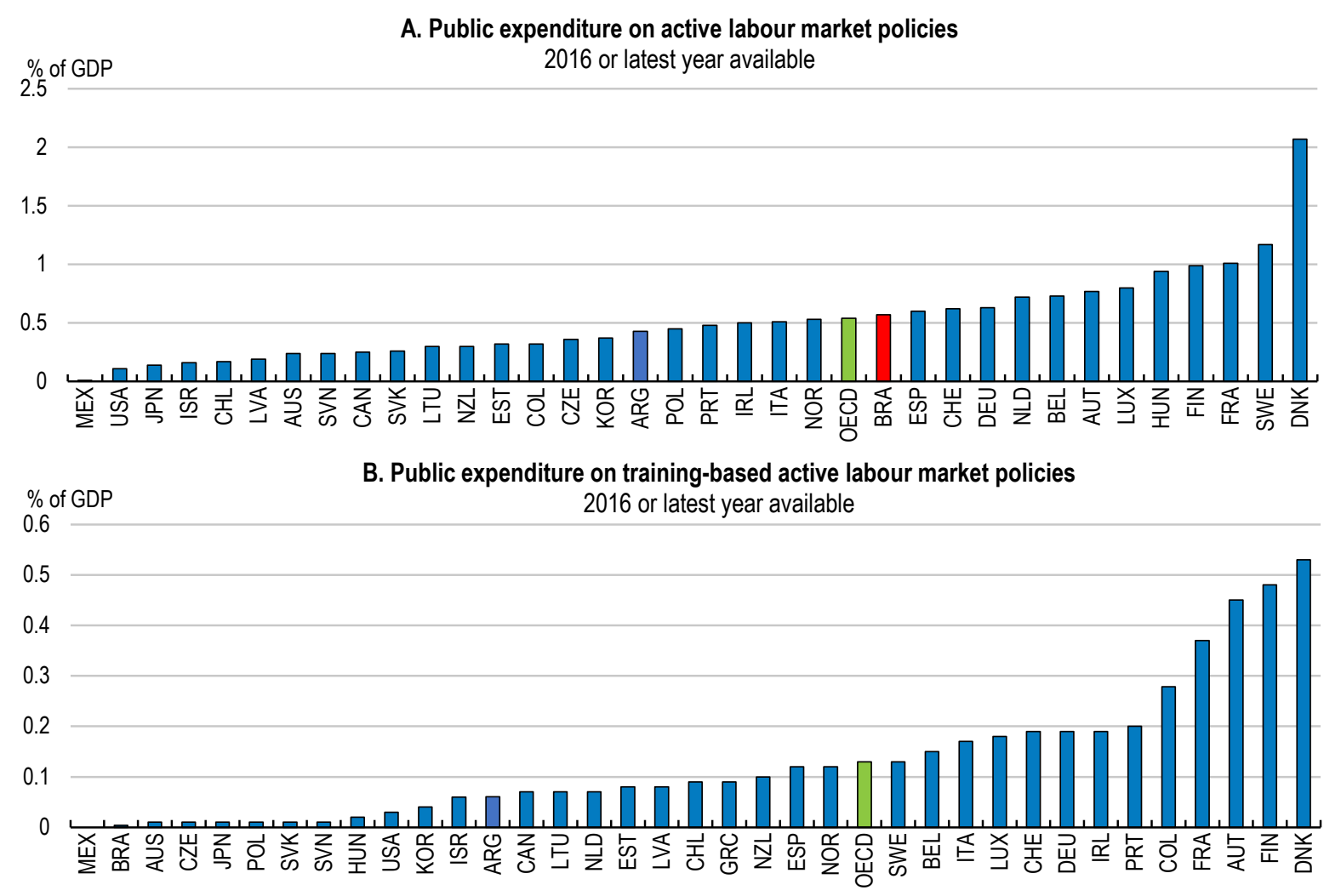

Source: ILO (2016).

StatLink त्ञात https://doi.org/10.1787/888934197563

\section{Aligning training supply with labour market demands is key}

Not only is spending for training and adult learning policies relatively low, the training and adult learning system has also been characterised by large spending inefficiencies (OECD, 2018[51]). From 2011 until 2018, Brazil implemented a large-scale training programme called PRONATEC in a coordinated effort involving various ministries. Training subsidies targeted particularly the poor and low-skilled parts of the population including informal and unemployed workers. The regional coverage was extensive and included many poor and remote areas.

An important shortcoming of PRONATEC, however, was a mismatch between course content and skill needs in local labour markets, at least for large parts of the programme (Box 3). In many cases, the type and content of subsidised training courses as well as the target population were centrally decided without taking into account skill demands and training needs in local labour markets (OECD, 2018[51]). Moreover, weakly designed incentives for training institutions led to a large heterogeneity in training quality, dropout rates and future employability of training graduates. The programme paid a fixed subsidy per enrolled student without any incentives related to content relevance, cost effectiveness or quality improvements. Evaluation was not mandatory. In those cases where private training providers had a say in choosing training content, they usually offered courses that could be set up or expanded quickly rather than those that were needed. Rapid expansion of course capacities weakened the selection criteria for teachers and reduced teaching quality. As a result, large numbers of workers enrolled in vocational training courses related to occupations for which labour demand was low (Figure 14). 
Figure 14. PRONATEC courses were poorly aligned with labour market needs

Number of students enrolled and indicator on relative labour demand (by occupation)

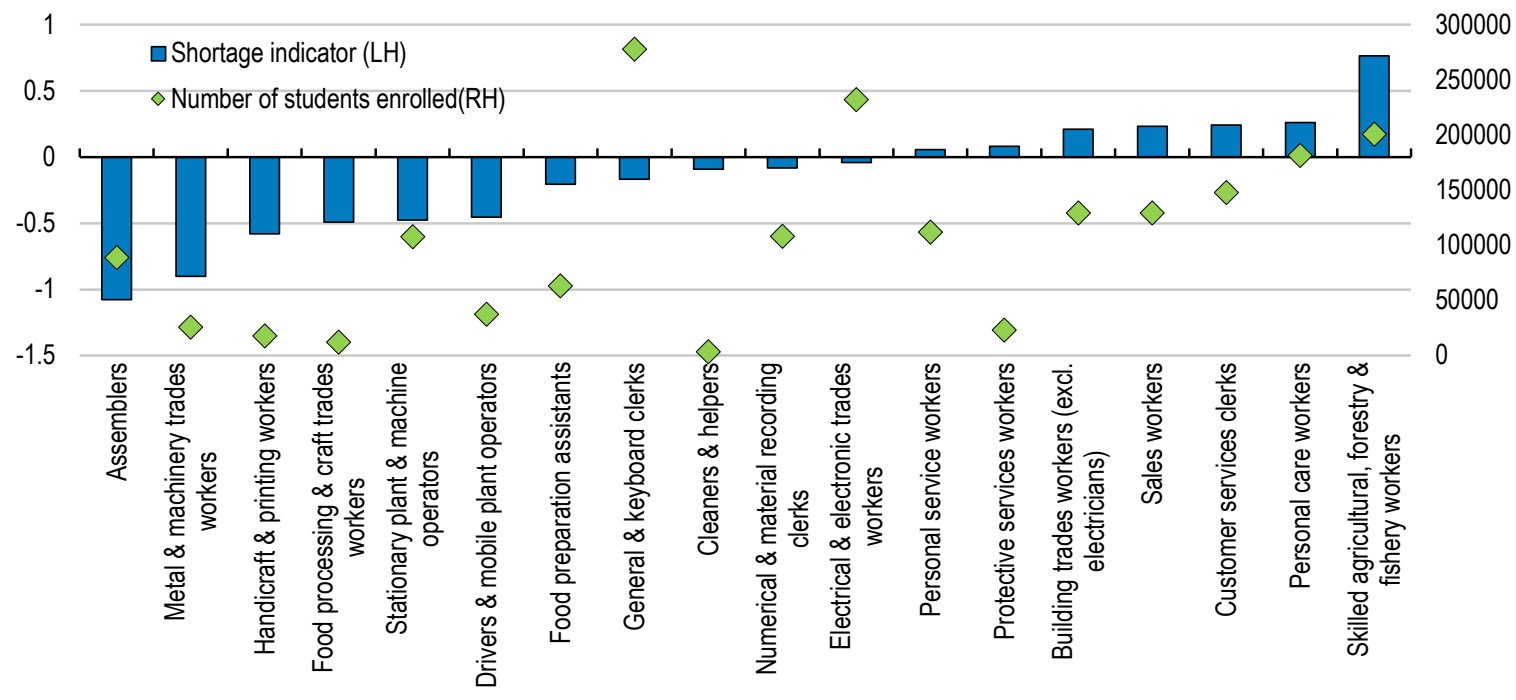

Note: The total number of students enrolled in the PRONATEC programme is depicted in the right-hand side vertical axis and the occupational shortage indicator is represented in the left-hand side axis. A negative value for the occupational shortage indicator means that the occupation is in surplus, i.e. firms have no difficulties to find workers with the right skills. A positive value for the indicator means that the occupation is in shortage, i.e. firms have difficulties to find workers with the right skills. Data for the shortage indicator refers to 2014. Data for the number of students enrolled refers to 2012-2018.

Source: SISTEC micro data set of PRONATEC students' records and OECD Skills for Jobs database, taken from (OECD, 2018[51]).

StatLink त्ञात https://doi.org/10.1787/888934197582

The assignment of students to training supply was also characterised by a lack of interaction with career guidance services, which are patchy and poorly structured. As a result, many low-skilled workers lacked the most basic skills to benefit from the course (OECD, 2018[51]). On the other hand, career counsellors had no access to information about past training participation, which prevented the design of consistent training agendas for individuals and further reduced the employability benefits from professional training for workers. A small part of PRONATEC, however, referred to as PRONATEC-MDIC or SuperTec and organised by the Ministry of Industry (MDIC), did not suffer from misalignment with labour market demands (Box 3.3).

\section{Current plans draw lessons from past weaknesses, but should go further}

Training policies are currently undergoing a comprehensive overhaul, with a particular focus on improving their cost effectiveness through more involvement of the private sector. An additional 1.3 million training places will be created, with the training supply based on a prior analysis of skill demand involving local productive sectors. These will be allocated via training vouchers handed out to firms between 2020 and 2022, strengthening the link between training choices and local firm needs. The training places will be created by SENAI, which is part of a semi-public network of training providers that receive part of their revenue from a national payroll tax. SENAI has played a major role in the provision of PRONATEC training courses and its regional coverage and training quality is high (OECD, 2018[51]).

The vouchers will allow firms to select the training participants and pay for the training they need. Training participation is not limited to current employees of the firm, but could include unemployed persons that the firm wishes to hire after the training. The engagement of private employers will lead to rising effectiveness of the training, as firms have an incentive to select the worker for whom the training will be most effective and will select training courses that reflect private sector skill demands. This approach has a strong focus on training those with greater expected benefits from training. 
However, there may be a case for expanding policy efforts beyond these low-hanging fruits, although that would require additional resources. The social benefits of expanding professional training programmes to make more space for those from disadvantaged socio-economic backgrounds could be substantial. In fact, there is a risk that the new training subsidy may not reach the workers that would need training the most: low-skilled, informal or unemployed workers that are particularly affected by the structural changes that trade opening or digitalisation will bring about (OECD, 2017[55]; OECD, 2019[26]).

To support this vulnerable group of workers, the government is planning to introduce social impact bonds to finance training provision. In this type of public-private partnership arrangements, providers would get significant autonomy in designing training courses and content, but their remuneration would be made contingent on specific outcome targets, such as the future employment rate of training participants. The potential success of such arrangements crucially depends on how contracts are designed (OECD, $2016_{[56]}$ ). In particular, the definition and measurement of social outcomes and the selection of target and control group to evaluate whether objectives have been met are complex tasks that entail significant transaction costs and risks for the public sector. So far, the empirical evidence on the effectiveness of social impact bonds has been mixed and governments should be careful in providing specific social services completely through these type of arrangements (OECD, 2016 $\left.{ }_{[56]}\right)$. However, as a complement to traditional forms of public social service provision, social impact bonds have the potential to nurture a culture of monitoring and evaluation in social service delivery, which is currently missing in Brazil.

Additional public resources will be required to effectively equip unemployed, low-skilled and informal workers with market-relevant skills that will allow them to share in the opportunities that lie ahead. The government should consider closely involving SENAI and related institutions in the design and implementation of targeted training policies for vulnerable workers, not least because these semi-public institutions receive payroll tax revenues of around $0.25 \%$ of GDP. Despite agreed quotas to include disadvantaged workers in its training courses, their number has in reality been low, which is partly related to a lack of enforcement of the agreed quotas (OECD, 2018[51]).

An expansion of training efforts should include a more systematic role for evaluations and subsequent refinements. Close cooperation with the private sector to detect changing skill requirements of occupations as well as systematic feedback from employed graduates should inform regular updates of training content and quality control. SENAI, for example, has established methods for training assessment and content update that follow international best practices (OECD, 2018[51]). Ongoing efforts to expand demand-driven SuperTec courses and collect training requests from local firms through an electronic platform should be expanded and combined with a skill anticipation assessment focusing on skill needs in local labour markets (Box 3). Best practice examples for region-specific skill anticipation exercises already exist in Brazil, including the work of SENAI in the state of São Paulo. Building on this success with a view towards covering all sectors and regions within the country could feed into region specific training catalogues (OECD, 2018[51]).

The current voucher system could be complemented with additional vouchers allocated to disadvantaged individuals. The allocation could be based on administrative data such as the comprehensive register of all poor households used to administer the conditional cash transfer programme Bolsa Familia. This could reduce registration and information costs and improve competition between training providers, if combined with a transparent quality certification system for training institutions (OECD, 2018[51]). The vouchers could be used to select courses from a region-specific training catalogue that is closely linked to private sector skill demands. Another option could be to allocate a certain share of places in courses requested by firms in the current voucher system to disadvantaged workers, following a successful experience in Singapore (Box 4). Incentivising the supply of evening, part-time or distance learning courses and linking the workerspecific subsidy to income or living area would facilitate the participation of disadvantaged workers living in remote areas. 
Career counselling and job placement services could be better linked with training programmes (Box 4). Matching trainees' skills and experience with training content is important to ensure the cost effectiveness of training. Access to courses could be made dependent on career counselling and an evaluation of the necessary prior-knowledge (Box 4). High dropout rates in PRONATEC training courses were often related to missing fundamental skills of trainees as well as unrealistic expectations about the course content and its objectives (OECD, 2018[51]). Counselling services could provide better information on training opportunities and help to direct those interested in training to the right course.

Moreover, job counsellors should have full access to individual training records and employment histories to better match job seekers with skill demands of firms and tailor training supply to individual needs. Improving and expanding the certification system for work competences, in particular for informal workers, would raise employability and improve the effectiveness of public employment services. It would also encourage training investments of workers (Dutz, 2018[40]). Current efforts by the government to share databases and engage private providers in job counselling services with performance-based remuneration could help to address some of the shortcomings of public job placement services in the past.

As many job-seekers lack required soft skills and on-the-job experience, training courses should be combined with soft-skill training and practical internships (Figure 15). A good mix of technical and soft skills such as communication and teamwork becomes increasingly important with rising international integration and digitalisation of the economy (OECD, 2019[26]; Grundke et al., 2018[31]; OECD, 2017[55]). For workers that have not completed basic primary education, the government should expand the provision of basic adult education courses as a prerequisite for accessing vocational training courses, as discussed below.

\section{Box 4. Targeting vocational training to vulnerable workers}

Allocating vouchers for subsidised training courses to disadvantaged individuals has been a successful strategy to enhance employability of low skilled, older and low- income individuals in many countries (OECD, 2019[57]). An important feature of successful programs has been to steer the use of vouchers to training content that is linked to labour market skill needs. Effective information and career guidance infrastructure have helped to increase take-up, and some countries even link the delivery of vouchers to the outcomes of career counselling.

In Korea, for example, unemployed individuals are required to attend career counselling before they can access the Vocational Competency Development Account (OECD, 2019 $\left.{ }_{[58]}\right)$. In Belgium, adults with tertiary qualification can only access training vouchers if career counsellors agree that training is necessary. Other countries restrict the use of vouchers to a list of pre-approved training courses. In Estonia, for instance, vouchers can only be used by individuals who enrol in training that is related to ICT skills or has been identified to develop skills that are in shortage in the labour market (OECD, $\left.2019_{[57]}\right)$. In Austria and Greece, vouchers are available for both the employed and the unemployed to develop digital skills while in Israel vouchers must be used to develop skills such as Real-Time, Java, or Application Development.

To reduce the administrative costs of targeting training to labour market demand, some countries have allocated vouchers directly to firms that could decide on training content and select workers for which the training would be most effective (OECD, 2019[26]). Singapore has made these vouchers conditional on the inclusion of low-skilled, informal or unemployed workers in these courses so that they could benefit from training directly mapping with firms' skill demands. However, the experience of Italy and Malaysia with their training funds shows that employers are not necessarily perfectly forward looking in their assessment of future skill demands, as a major part of the funding is used for safety and health related training and very little for training related to ICT skills (OECD, 2019[59]). 


\section{Figure 15. Firms have difficulties to find the workers they need}

Main reasons for why firms in Brazil do not find the workers they need

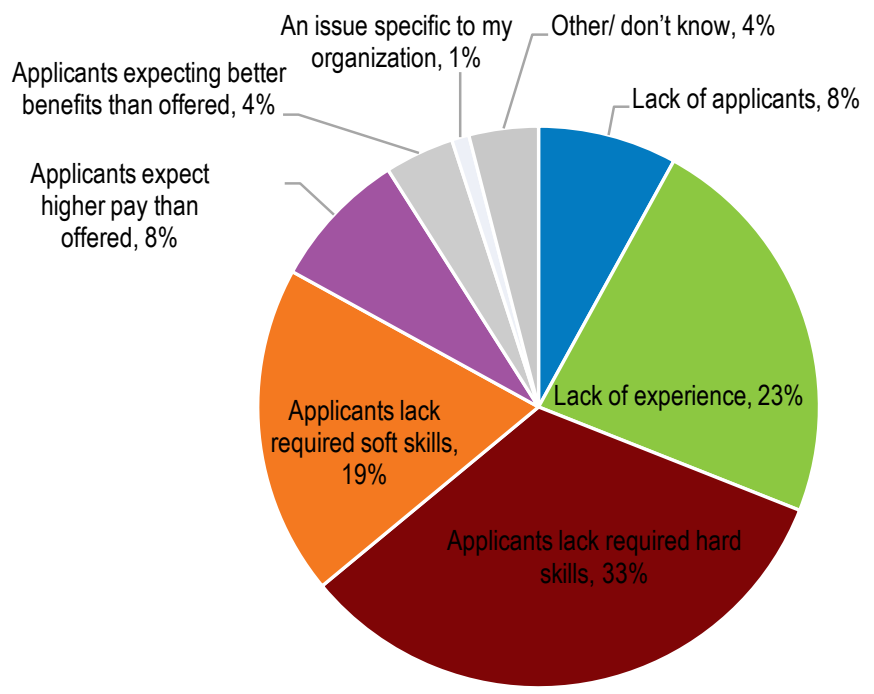

Note: The information is based on opinion surveys of business leaders.

Source: 2018 Talent Shortage Survey, Manpower group.

Finally, improving management and organisational skills in small and medium size firms can be a very effective way to increase human capital investments and on the job training for workers (Dutz, 2018[40]). It also has potential to significantly raise the productivity of firms in Brazil and contribute to the reduction of informality. Many small and medium size firms in Brazil suffer from weak management practices and underinvestment in human capital of their staff (Bloom and Reenen, 2010[60]). Subsidising targeted training for managers of small firms can be a suitable policy tool to improve human resource management and prepare low-productivity firms for rising domestic and international competition (Dutz, 2018[40]). On a small scale, the government has already launched such a programme, whose impact should be carefully evaluated before upscaling it.

Beyond publicly subsidised training programmes, it will also be important to improve the incentives for private training provision by employers. At present, the design of the unemployment insurance scheme FGTS creates incentives for high job turnover, which in turn reduces the benefits for firms to invest in the skills of their staff. Informality is another factor for low investment of firms in training of staff (Dutz, 2018[40]). These structural factors holding back private training provision should be addressed by rethinking current unemployment insurance schemes as well as labour taxes and regulations (OECD, 2020[2]).

\section{Improving education policies}

While professional training is an effective way to reach those already in the labour market and whose basic skills allow a successful upgrading of specific job-related capabilities, the education system plays a fundamental role in preparing current and future generations for the challenges that international integration and rising digitalisation will bring about. Automation and offshoring may lead to the redundancy of certain tasks or occupations, which might require workers to change occupations and pursue new formal education degrees at a later stage of their careers (Bechichi et al., 2019 [34]; Hummels et al., 2012[23]; Autor et al., 2014[20]; Hyman, 2018[22]). Therefore, it is crucial to lay good fundamentals in cognitive and social 
skills already early in life to facilitate learning and adaptation at a later stage (OECD, 2019[26]; Heckman and Mosso, 2014[61]; Heckman, Pinto and Savelyev, 2013[62]; Heckman et al., 2010[63]).

\section{Access to education has increased, but education quality is still weak}

During the last decades, Brazil has strongly increased education spending and improved access to basic education. In many poor and remote municipalities, school infrastructure significantly improved and many new teachers were hired (IBGE, 2019[64]). Enrolment rates have strongly increased for early childhood, primary and secondary education (OECD, 2019[65]). The share of young adults having completed upper secondary education reached $46 \%$ in 2018 , which is 20 percentage points higher than for older workers and at par with the OECD average (Figure 16). The share of young adults having completed tertiary education has also increased compared to the older generation, but is still 20 percentage points below the OECD average (OECD, 2019[65]).

\section{Figure 16. Educational attainment has strongly increased}

The share of adults having completed upper secondary or post-secondary education in 2019 (in \%)

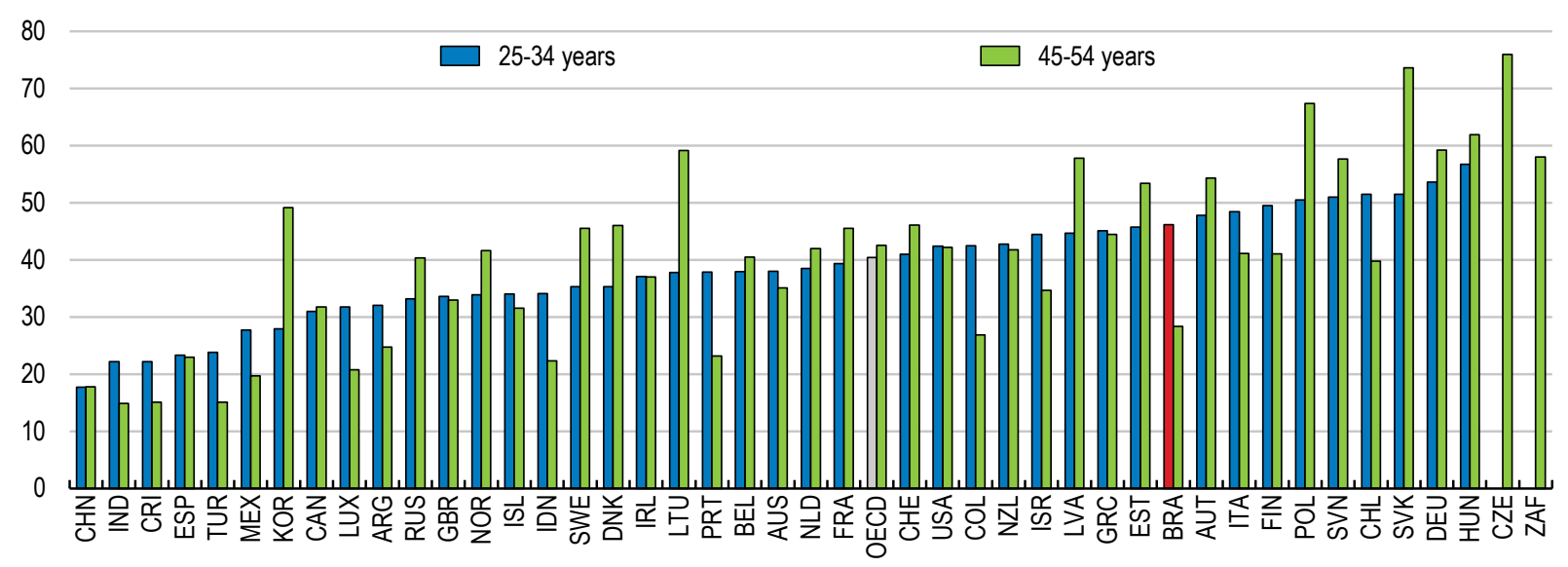

Source: Education at a Glance 2020.

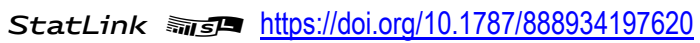

Rising access to education has not been accompanied by increases in the quality of education. Comparing PISA test scores of 15-year-old students, Brazil ranks lower than other Latin American countries or the OECD average, although its education spending is with $6.2 \%$ of GDP even higher than in the average OECD country (OECD, 2020[2]). Since 2009, test scores for reading, mathematics and science have not improved much relative to the OECD average (Figure 17). Moreover, dropout rates in secondary education are still higher than $30 \%$ (OECD, 2019 $\left.{ }_{[65]}\right)$. This is related to large heterogeneity between schools in terms of teaching quality, a curriculum that has focused on academic content and very little on vocational education and training, and a lack of basic cognitive and social skills among children from low-income families (INSPER, 2017[66]). 
Figure 17. Educational quality is weak and has not improved much

Brazil performance in PISA relative to OECD average by PISA cycles

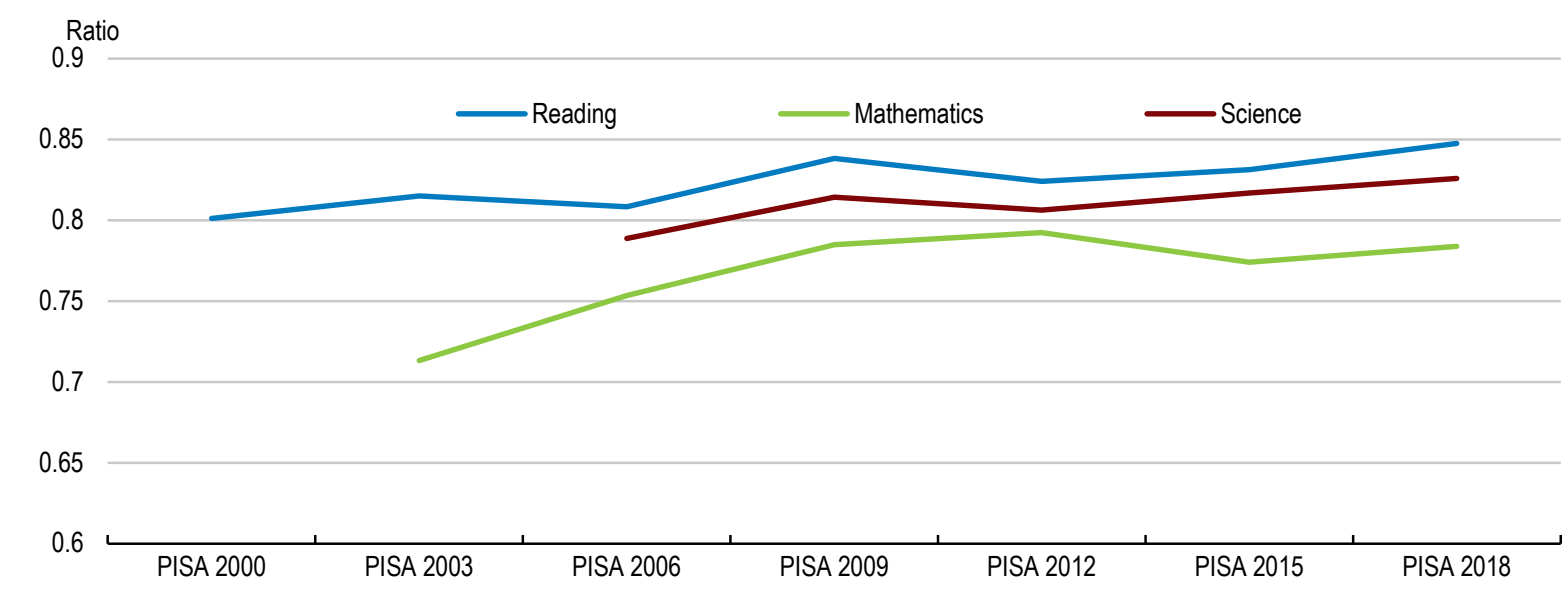

Source: OECD, PISA 2018.

\section{Improving the quality of basic education}

In recent years, significant steps were taken to improve the quality of basic education, but challenges related to implementation remain. Nation-wide common learning standards, which comprise a rich set of cognitive and socio-emotional skills and hold up to international best practices, have been introduced for early-childhood, primary and secondary education. The new common core for upper secondary education introduces more flexibility in course choice including a vocational training track, which has strong potential to reduce dropout rates (INSPER, 2017[66]). The new standards also increase minimum schooling duration from four to five hours per day. However, due to large heterogeneity in resources and technical capacities across municipalities and states, the implementation of the new nation-wide standards will be challenging.

A highly decentralised education system combined with large economic disparities has led to high variation of education quality and outcomes across municipalities (IBGE, 2019[64]; Todos pela educação, 2018[67]). The constitutional authority for early-childhood and primary education until the 5 th grade lies in the hands of over 5000 municipalities, which are responsible for curriculum design and implementation, teacher selection and training, and design of learning material within their jurisdiction. Although a federally funded redistribution fund called FUNDEB has mitigated funding inequalities to a certain extent, resources and technical capacities are still low in many municipal school networks. Until the recent establishment of nation-wide standards, many municipalities did not have systematic learning standards, teachers have not been trained to properly implement existing standards and there was little coordination across municipalities. For the new standards to be effective, the federal and state governments need to take the lead and coordinate the implementation of standards and the common national curriculum into teaching practices in municipal and state school networks. They should continue to support local governments in teacher training and design of learning materials. As a first step, national guidelines for teacher training and the national textbook programme have been aligned with the content of the common national curriculum.

Coordination has also been weak across different levels of government and led to high spending inefficiencies in secondary education (Economistas do Brasil, 2018[68]). The constitutional authority for lower secondary education from the 6th to 9th grade is split between municipalities and states. School networks co-exist in many communities without any coordination or pooling of resources to use synergies 
(Todos pela educação, 2018[67]). States are responsible for upper secondary education from the 10th to 12th grade, and there has been little coordination in learning standards and their implementation with lower secondary municipal school, nor with school networks in other states. Moreover, in many poor communities, the existing school infrastructure and teaching staff is insufficient to comply with the new mandated minimum schooling hours or to provide the range of subject choices foreseen in the new learning standards for upper secondary education (Todos pela educação, 2018[67]). Although the new standards are an important step, implementing them will require continued coordination among different levels of government.

The quality of education will only improve with better selection and training of teachers. Although incentive based payment might increase motivation, these incentives will be ineffective if teachers do not have the skills they need for the job (Todos pela educação, 2018[67]). Teachers are located at the lower end of the skill distribution of tertiary education graduates in Brazil. This is related to the fact that rapidly increasing access to basic education was only possible with an accelerated hiring of teachers combined with weaker selection criteria. Moreover, relatively low wages in the teaching profession have contributed to the selfselection of lower-skilled graduates (IBGE, 2019[64]). The allocation of additional resources to under-funded municipal school networks through the new FUNDEB will help attracting higher-skilled graduates to the teaching profession.

Moreover, recruitment procedures for teachers should be standardised nationwide including common tests and certifications, possibly mimicking existing recruitment procedures for public employees. The recruitment system could classify candidates according to several criteria to improve the matching of teachers to open positions with differing skill requirements. Skill needs vary widely across school types, such as early-childhood, primary or secondary education, but also according to the socio-economical background of children.

Besides selecting the right candidates, teacher training needs to improve and adapt to the new learning standards. The national curriculum guidelines for initial teacher training for basic education, approved in December 2019, are a step into this direction. Curriculums for teacher careers at many universities include very little pedagogical knowledge or practical experience in classrooms (INSPER, 2017[66]; Todos pela educação, 2018[67]). Once young graduates have been hired, they face highly heterogeneous levels of counselling and training on the job. Most graduates do not get any support during their first years in school and there is no regular evaluation of their performance. Weak management of schools is related to frequent political appointments of school principals, which strongly influences the quality of teacher training and motivation (INSPER, 2017[66]; Todos pela educação, 2018[67]).

Besides teaching quality, socio-economic background and good early-childhood education are the main determinant for educational outcomes (OECD, 2019 $9_{[69]}$; Heckman and Mosso, 2014[61]). In particular for young children, the access to food, clean drinking water and good health services is crucial for the development of cognitive and social skills (Heckman, Pinto and Savelyev, 2013[62]; Heckman et al., 2010[63]). Thus, recent increases in enrolment rates for early childhood education should be complemented with continued efforts to eradicate extreme poverty, raise access to universal health care and improve municipal water and sanitation services (IBGE, 2016 $[70]$ ). Moreover, improving internet access for lowincome households is key to enable distance learning, which during the school closures due to the Covid19 pandemic has been the only way to participate in schooling activities and will play an increasing role in skills development throughout life (OECD, 2019[26]).

Shifting more resources to the successful conditional cash-transfer programme Bolsa Familia would be one way to improve access to food and health care for many poor children. Food could be directly provided in schools to ensure nutrition quality. Eventually, the programme could also be linked to enrolment in early childhood education or home visits of teachers consulting parents on education practices. When allocating scarce spaces in early childhood education, preference should be given to low-income households and 
single mothers. Only $15 \%$ of poor families with children below 3 years have access to child-care, compared to $40 \%$ of the more affluent families (World Bank, 2016 $6_{[71]}$ ).

\section{Preparing low-skilled adults for the challenges of the future}

Due to low access to basic education until some decades ago, a large share of adults has not completed primary education (Figure 18). The share of older workers who cannot read or write is still large compared to other countries (IBGE, 2019[64] ). Although enrolment rates of adults into formal education are higher than in the average OECD country, the quality of basic education for adults is low and many drop out before graduating (Todos pela educação, 2018[67]; IBGE, 2019[64]). There is no separate targeted system of adult education. Adapted learning standards, curriculums or learning material as well as specific teacher training or selection do not exist. In most municipalities, the same teachers who teach children in basic education may be teaching adults in their second or third day shift. The supply of specific facilities for adult education is low and often classes take place in regular schools or other municipal buildings.

As opening up the economy will require many low-skilled workers to find new jobs in other firms or economic sectors, it is key to reform the current system and increase its funding. Current transfers for adult education from the federal government to municipalities are not conditional and mostly spend on basic education of children. The government should consider including basic education of adults in the federal top-up mechanism for education funding FUNDEB and combine funding allocation with the same type of quality improving incentives for municipalities and states. To inform education policies on skill needs of adults, Brazil could consider participating in the OECD Survey of Adult Skills (PIAAC).

\section{Figure 18. The share of adults without completed basic education is high}

Educational attainment of 25-64 year-olds (2018)

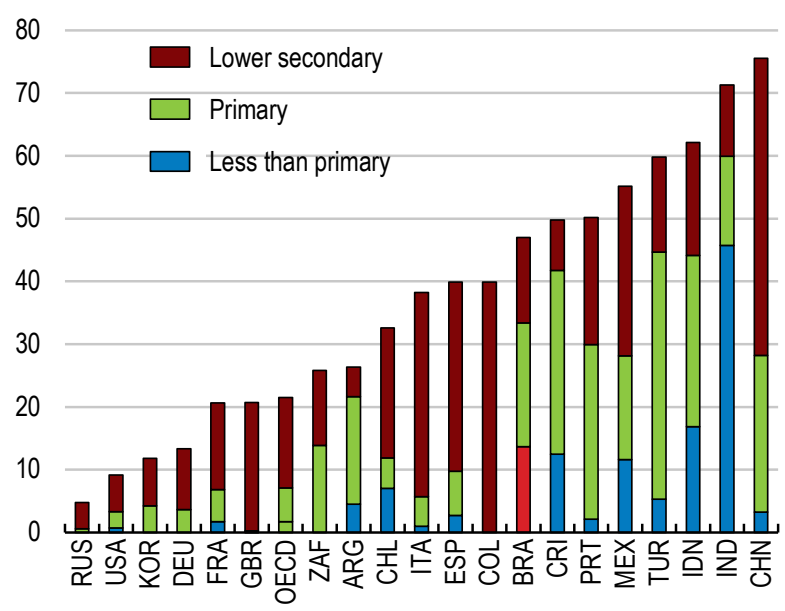

Enrolment in formal education, below upper secondary education (2017)

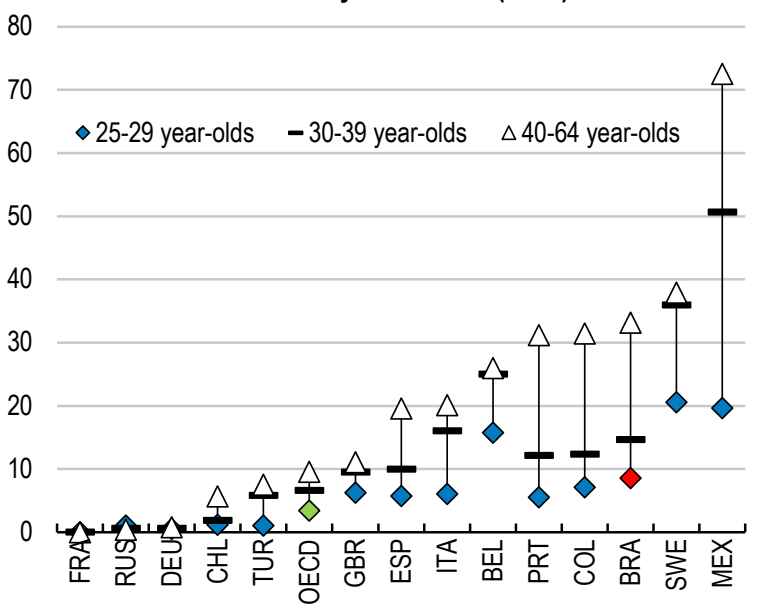

Source: OECD, Education at a Glance 2019.

StatLink 제내 https://doi.org/10.1787/888934197658

As the share of adults without completed primary education is particularly large among older and poorer parts of the population (Figure 19), it is key that learning standards, curriculums and teaching material as well as teacher selection and training are specifically adapted to these target groups (IBGE, 2019[64]). This requires a concerted national effort and a strong coordination among different levels of government. To support poor households and facilitate school attendance of working adults, increasing funding for Bolsa Familia could be combined with requirements for parents to attend basic education. This could even 
generate synergies for poor children, whose parents might be in better conditions to support them in their educational career.

\section{Figure 19. Particularly old workers have low educational attainment}

Educational attainment by age, 2018

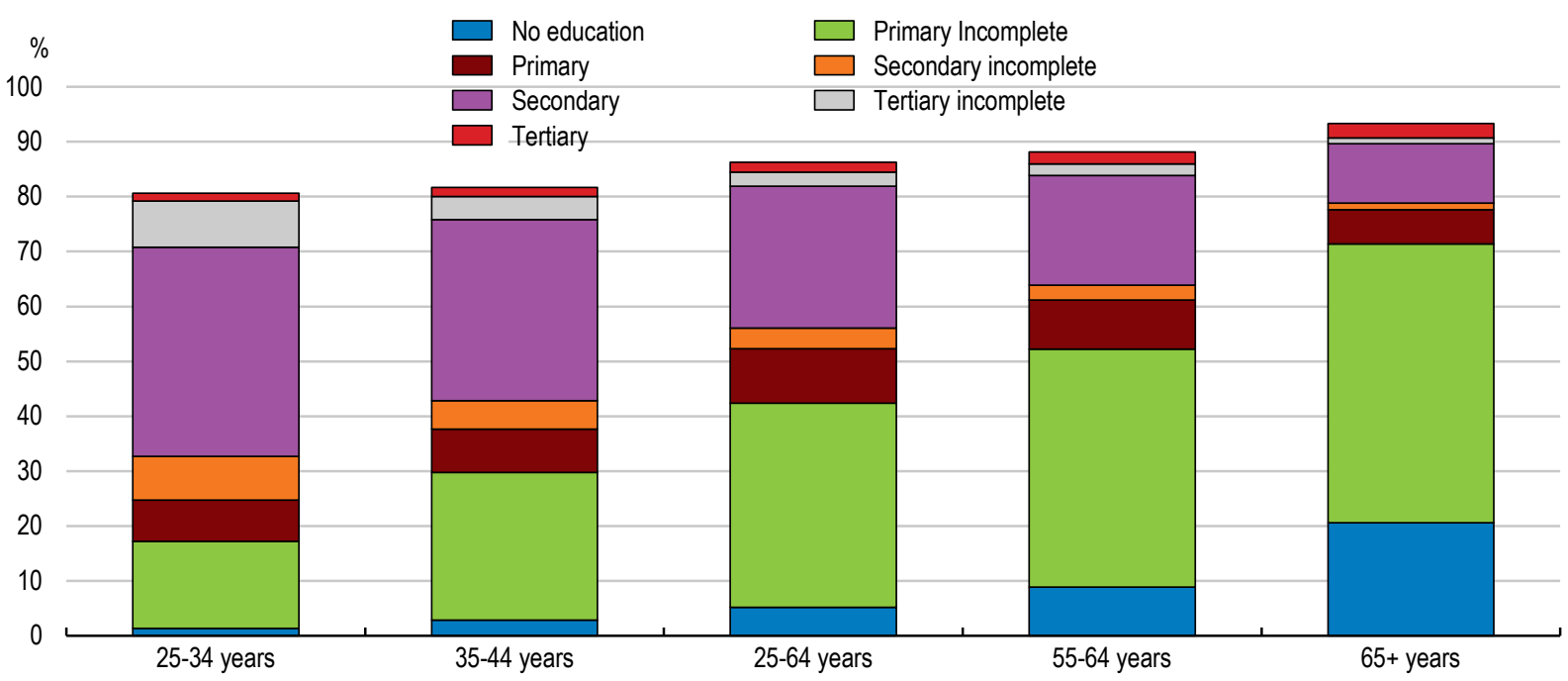

Source: IBGE. Pesquisa Nacional por Amostra de Domicílios Contínua, $2^{\circ}$ trimestre, 2018.

\section{Improving access to vocational education and apprenticeships}

For many students, the strong focus of secondary curriculums on academic subjects and a lack of opportunities to select courses according to their interest or ability may be one factor behind frequent class repetition and school dropout (Figure 20). Professional training opportunities within secondary education are currently scarce. Expanding them could help to reduce high dropout rates (INSPER, 2017[66]).

A 2017 education reform that established nation-wide learning standards and curriculums for upper secondary education laid the grounds for offering more vocational content in secondary education. Mandatory subjects are reduced to 1800 hours per year. For the remaining 1200 hours, student can choose among five different paths, including mathematics, science, languages, humanities and vocational education. This newly created flexibility is a major step forward, but challenges related to implementation remain. Many states and municipalities do not have the necessary resources and capacities to implement all five pathways (Todos pela educação, 2018[67]; Almeida and Packard, 2018[72]). Both physical school infrastructure and the availability of adequately trained teaching staff are severe bottlenecks, which will require additional resources and better coordination across different levels of government (OECD, 2020[2]). For example, idle facilities from federal and state institutes that had expanded their training capacities in recent years under the umbrella of the PRONATEC programme could be used for vocational education classes.

For the new vocational education path in upper secondary education to be successful, the close cooperation and involvement of the private sector in design and delivery of workplace training is key. So far, vocational education is mainly taking place at post-secondary level and most state and federal institutes for vocational education do not offer much practical experience (OECD, 2019[65]; OECD, 2018[51]). The semi-public network of training providers "Sistema S", including SENAI for the manufacturing sector, are a 
notable exception. Sistema S institutions have developed strong ties with the private sector and offer high quality vocational education, including practical experience in firms or training laboratories (OECD, 2018[51]). Their courses are linked to skill demands in the private sector and course content is regularly updated using skill anticipation assessment and graduate surveys. However, there is very little cooperation with high schools and most students start their vocational education after completing high school. Recent efforts to include "Sistema S" training providers in the design and implementation of the new vocational education path in secondary education are promising and should continue.

\section{Figure 20. Opportunities for vocational training in upper secondary education are low}

Share of vocational students of all upper secondary students, 2018

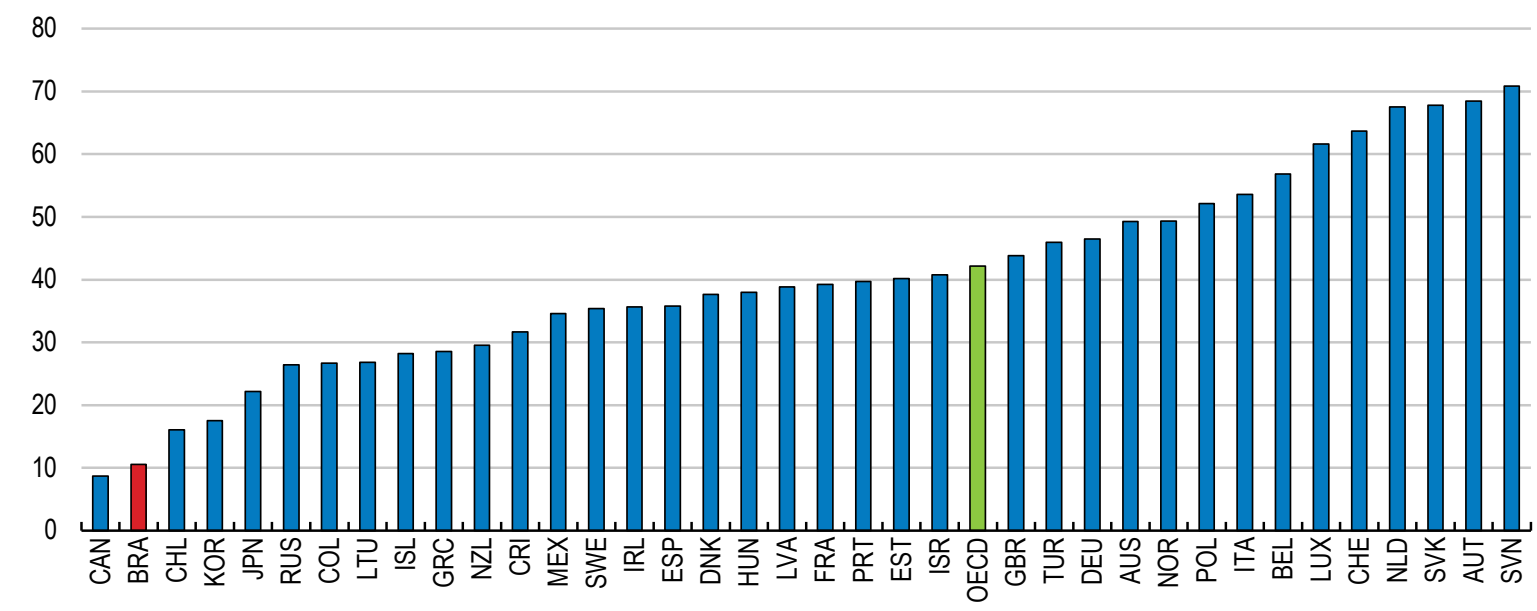

Source: OECD, Education at a Glance 2020.

StatLink 제내 https://doi.org/10.1787/888934197696

Vocational education institutes close to the private sector are reluctant to cooperate with high schools due to excessively restrictive work safety and health standards, which complicate practical vocational education for minors in firms or at machines in laboratories (Silva, Almeida and Strokova, 2015 [39]; Almeida and Packard, 2018[72]). Uncertainty around judicial decisions have led to closedowns of private-sector institutes with integrated vocational education in upper secondary education, such as one previously operated by the car manufacturer Volkswagen. These labour safety and health standards should be simplified to facilitate cooperation between high schools and the private sector in the implementation of the new vocational education path in secondary education.

The experience of the United Kingdom may also serve as inspiration for providing monetary incentives for firms to offer apprenticeships. In the UK, a specific apprenticeship levy of $0.5 \%$ of total payroll is collected from firms with a wage bill of more than USD 4 Million (NAO, 2019[73]). These firms can use their contribution to select coursework or other instructional services related to apprenticeships from a dedicated digital portal, and receive a $10 \%$ top up from the government. For smaller firms not paying the levy, access to these courses requires a co-financing of $5 \%$ of the costs. Apprentices must spend at least $20 \%$ of their paid hours doing off-the-job formal training. However, a wider use of apprenticeships in Brazil would likely require addressing negative training incentives related to high job turnover and the policy distortions behind it, as discussed above. The experience of Germany shows that the main motivation for firms to offer apprenticeships is to secure its future supply of skilled workers (Grollmann et al., 2016[74]). 


\section{Improving access and quality in tertiary education}

Access to tertiary education has increased and $20 \%$ of young adults had a completed tertiary degree in 2018 , but this is still over 20 percentage points below the OECD average ( (OECD, 2019[65])). Public tertiary education is virtually free in Brazil, but the selective admission tests put children from public schools at a disadvantage vis-à-vis graduates from private schools, where the quality of secondary education is generally higher (IBGE, 2019 $\left.9_{[64]}\right)$. This makes spending on tertiary education largely regressive. Recently introduced admission quotas have been successful in raising the share of students from disadvantaged groups of the populations and should continue. Another alternative would be to introduce means-tested university fees with ample scope for grants for students from low-income households.

The most effective way to improve the opportunities for students from low-income families in tertiary education is to prepare them better before they graduate from secondary school. This suggests that the current focus could be shifted from relatively high spending on tertiary education towards earlier levels of education (Figure 21). Tertiary education also suffers from quality shortcomings and low completion rates (Economistas do Brasil, 2018[68] $)$. More than $50 \%$ of students have not completed their degree three years after the end of the theoretical duration (Figure 21).

\section{Figure 21. Spending for tertiary education is relatively high, but dropout rates are high}
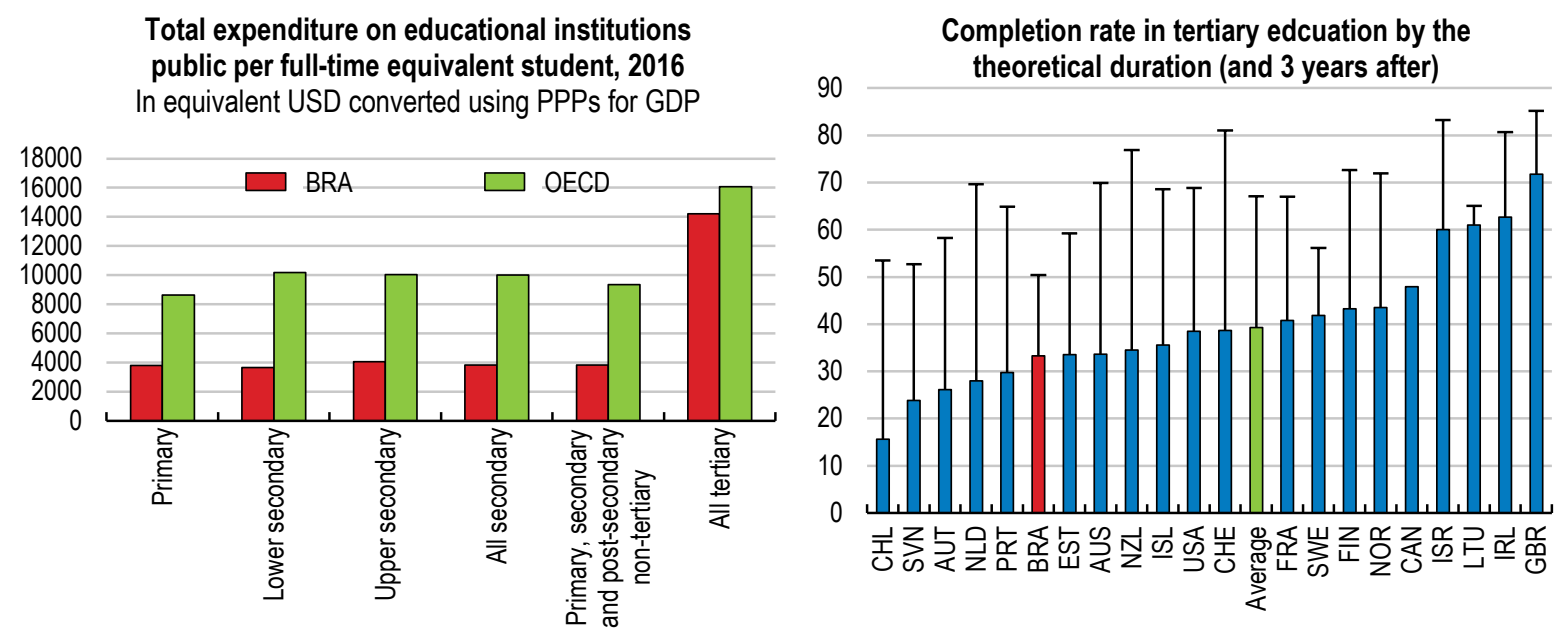

Source: OECD, Education at a Glance 2019.

Reducing dropouts in tertiary education would require strengthening the alignment of university curriculums to the type of occupations and skills demanded by the labour market (Economistas do Brasil, 2018[68]; OECD, 2019 $9_{[65]}$ ). Many firms in Brazil indicate that university graduates do not have the technical and social skills they need (Schwab, 2019 $9_{[75]}$ ). Skill demand is particularly high in science, technology, engineering and mathematics (STEM), but only $13 \%$ of tertiary graduates study these fields, compared to $20 \%$ in the OECD average or $26 \%$ in Mexico ( (OECD, 2019[65])). The federal government should consider linking admission rates for university subjects to a nation-wide skill anticipation assessment system, which would indicate which type of occupations are in high demand in the labour market. Curriculums should be regularly updated and linked to changing skill requirements and task content of occupations.

Student choices could also be guided by transparent assessments and certifications of tertiary education courses, to inform high school graduates about the quality and the content of these courses (Economistas do Brasil, 2018[68]). This could be combined with career counselling services for high school students to well align interest and abilities with the content of selected tertiary education courses. 


\section{Box 5. Policy recommendations for improving skills}

\section{Key recommendations}

- Scale up resources for professional training policies, in particular for low-skilled, unemployed and informal workers, and link subsidies for training providers to employment outcomes.

- Continue expanding access to early-childhood education, prioritising access for low-income families and single mothers.

\section{Other recommendations}

- Align training supply with labour market demand using skill anticipation assessments and multistakeholder dialogue at the local level.

- Complement training vouchers for firms with vouchers for low-skilled, informal and unemployed workers to allow participation in training courses demanded by firms.

- Establish systematic evaluations and certifications of training programmes.

- Improve the certification system for work competences to enhance employability, in particular for informal workers, and raise the effectiveness of public employment services.

- Improve the quality of basic education for adults by increasing resources for municipalities and states through including adult education funding into FUNDEB and introducing nation-wide learning standards and curriculums.

- Coordinate teacher training and the design of curricula and learning material across municipalities and states to properly implement the new nation-wide learning standards.

- Consider raising teacher remuneration through temporary bonuses to qualified teachers for teaching in difficult schools.

- Improve teacher selection through introducing nation-wide standardised tests and allocate teachers to schools according to differing skill needs across school types.

- Standardise curriculums for teacher education nation-wide including more practical experience and make regular evaluation and support mandatory during the first years on the job.

- Reform work safety and health standards to facilitate cooperation with the private sector to include practical experience into the new vocational education pathway in secondary education.

- Better align university curriculums with labour market needs and introduce a transparent assessment and certification system of tertiary education courses.

- Consider participating in the OECD Survey of Adult Skills (PIAAC) to inform education and training policies on skill needs. 


\title{
Annex: Additional details on the empirical analysis
}

\author{
A1. The economy-wide effects of trade liberalisation - simulations using the \\ OECD Metro model
}

The current structure of import protection in Brazil varies considerably across different sectors of the economy. Tariff rates are high for textile, wearing apparel, leather and furniture industries, and non-tariff measures particularly protect food processing, transport equipment as well as machinery and equipment industries (Cadot, Gourdon and van Tongeren, 2018[46]). Services sectors also differ in their openness to foreign competition, with banking, insurance, media and broadcasting as well as logistics showing the highest barriers to foreign entry (OECD calculations based on the STRI index). Lowering these trade barriers will lead to reallocation of labour across sectors with substantially different skill-requirements (Bechichi et al., 2019 $9_{[34]}$ ). Identifying existing sectors with particularly strong challenges and large expected training needs as well as those sectors with particularly strong future employment potential can help to target training and education policies effectively.

\section{A1.1. The methodology}

Static computable general equilibrium (CGE) models are a common analytical tool to investigate the effects of trade liberalisation on the reallocation of production factors across sectors. These models combine the supply and the demand side of an economy, and try to capture the numerous feedback effects caused by trade policy changes. They model input linkages between economic sectors as well as markets for production factors, assuming that factors are mobile across sectors, and that total factor endowments in the economy are fixed and fully employed. Thus, tariff changes affecting output in one sector also have repercussions on other sectors by changing the demand and prices for inputs and production factors. These models also capture the feedback effects of changing income of workers and relative prices of goods and services on private consumption as well as the interlinkages of disaggregated sectoral trade flows.

To analyse the economy wide effects of a reduction in import protection for Brazil, simulations have been undertaken using the OECD METRO model calibrated for this analysis to 22 regions (focusing on G20 economies), 23 economic sectors, and 8 production factors. This static CGE model relies on a comprehensive specification of all economic activity within and between countries (and the different interlinkages that tie these together) and assumes fixed endowments and full employment of production factors. The simulations represent medium-term shocks where production factors are mobile, but there is no capital accumulation. It has been used widely in trade analysis to simulate the effects of domestic trade policy reforms in an international environment (OECD, 2015 $[47])$.

The OECD METRO model builds on the GLOBE model (McDonald and Thierfelder, 2013[76]). The novelty and strength of the METRO model lies in the detailed trade structure and the differentiation of commodities 
by end use, e.g. commodities designed for intermediate use, for use by households, for government consumption, and for investment. The underlying framework of METRO consists of a series of individually specified economies interlinked through trade relationships. As is common in CGE models, the price system in the model is linearly homogeneous, with a focus on relative, not absolute, price changes. Each region has its own numéraire, typically the consumer price index, and a nominal exchange rate (an exchange rate index of reference regions serves as model numéraire). Prices between regions change relative to the reference region.

The model is firmly rooted in microeconomic theory, with firms maximising profits and creating output from primary inputs (i.e. land, natural resources, labour and capital), which are combined using constant elasticity of substitution (CES) technology, and intermediate inputs in fixed shares (Leontief technology). Households are assumed to maximise utility subject to a Stone-Geary utility function, which allows for the inclusion of a subsistence level of consumption. All commodity and activity taxes are expressed as ad valorem tax rates, and taxes are the only income source of the government. In this study, the government is assumed to maintain an internal balance by adjusting its expenditure, tax rates are fixed. At the same time, the trade balance is fixed, and the nominal exchange rate is flexible in the simulations. Wages and the remuneration rates of all other factors (land, capital, natural resources) are assumed to adjust to equilibrate the factor markets.

The database of the model relies on the GTAP v9 database (Aguiar, Narayanan and McDougall, 2016[77]) in combination with the OECD Inter-Country Input-Output Tables, which are the main source of the OECD Trade in Value Added (TiVA) data, and allows the model to distinguish trade for use in intermediate production or final demand. The dataset contains 61 countries and regional aggregates and 57 commodities. Policy information combines tariff and tax information from GTAP with OECD estimates of non-tariff measures on goods, trade facilitation and export restricting measures as well as OECD estimates of services trade restrictions. The final model has been used to simulate a unilateral decrease of Brazil's currently applied tariffs and non-tariff measures to the lowest levels among G20 countries as well as its services trade restrictions to the average level among $\mathrm{G} 20$ countries.

\section{Incorporating the effect of improved access to inputs into the OECD METRO model}

In the context of this study, the OECD METRO model has been extended to incorporate a productivityenhancing effect of improved access to foreign inputs. When firms are constrained in their choice of using imported inputs or capital goods, they are likely to pay higher prices and may have to source lower-quality input and capital goods. Lower trade barriers can bring down prices, but also raise the quality of these inputs. This may be the result of rising imports, but also of the reaction of domestic producers to rising competition. Many domestic producers of intermediate and capital goods would likely react to the stronger foreign competition by upgrading their production processes and improving their products (Amiti and Khandelwal, 2013[78]; Topalova and Khandelwal, 2011[79]; Pavcnik, 2002[13]). As a consequence, the improved sourcing options for intermediate inputs and capital goods would allow domestic firms to upgrade their production processes through technology embedded in new inputs and machinery (Amiti and Konings, $\left.2007_{[5]}\right)$.

To incorporate this productivity-enhancing effect of improved access to foreign inputs into the OECD METRO model, the elasticity of labour productivity with respect to input tariffs is estimated for Brazil using sectoral panel data, as described below. This elasticity is then linked to the production efficiency factor in the model, where the size of the Hicks-neutral technological shock at the sectoral level equals the respective percentage change in sectoral tariff and non-tariff measures multiplied by this elasticity and adjusted by the share of labour in total factor demand in the sector. This shock is applied additively to the product efficiency parameter at the top of the nested CES production function.

To estimate the elasticity of labour productivity with respect to input tariffs for Brazil, this study uses a sector-level panel dataset for Brazil from 1995 until 2011, which provides information on sectoral input 
tariffs, employment and production. Employment and production data for 33 economic sectors (including 2 natural resource, 16 manufacturing and 17 services sectors) come from the OECD Trade in Value Added (TiVA) database (Dec 2016).

To measure average tariffs for inputs at the sectoral level, this study uses OECD data on average tariffs by industry and end use categories (capital goods, intermediate inputs, final consumption goods) for the years 1995-2011. Average tariffs by industry are calculated by computing the weighted average of product level tariffs within the industry, where import values are used as weights. Product-level tariffs are applied tariff rates (AHS) at the HS 8 digit level, if these are not available preferential rates or most-favoured nation (MFN) rates are taken instead. The industry-level tariff data are then weighted using input-output coefficients to obtain measures of average input protection for each of the 33 final goods sector. The inputoutput coefficients are constructed from OECD TiVA data as the share of inputs from the origin sector in total input use of the final sector. These shares are used as averages over the years 2003-2007to reduce the potential effect of business-cycle fluctuations. This procedure allows constructing average input tariffs for 33 economic sectors over the years 1995-2011.

To analyse the effects of input protection on employment, production and labour productivity, the following regressions are estimated for each dependent variable (in logs) using a fixed effects estimator:

$$
\log \left(\text { dependent variable }_{i, t}\right)=\beta \log (\text { inputtariff })_{i, t}+\gamma_{i}+\delta_{k, t}+u_{i, t}
$$

Where the subscript $i$ denotes the sector and $t$ the year. The independent variable of interest is the average input tariff for the sector (inputtariffs), which enters the specification in logarithmic form. Thus, the coefficient $\beta$ represents the elasticity of the dependent variable with respect to an increase in average input tariffs. Fixed effects for the economic sector $\left(\gamma_{i}\right)$ absorb all unobservable time-invariant sector-specific characteristics. Moreover, aggregated sector-year dummies $\left(\delta_{k, t}\right)$ control for all unobserved time varying effects that affect all economic sectors within one category of the aggregated sector classification at the same time. This classification aggregates 33 economic sectors into six broad sectors ( $k$ ), including resource based, light, middle and heavy manufacturing, market services and public services. Robust standard errors are used to account for potential heteroscedasticity.

Table 2 shows the results for the preferred specification in equation (1). The input tariff elasticity of labour productivity is estimated to be -0.22 , which means that an increase in average input tariffs by $10 \%$ decreases output per worker by $2.2 \%$. As regressions control for industry fixed effects and sector-year dummies, identification only uses variation within industries across time that is not explained by variation of aggregated sectors across time. Thus, any time constant industry specific characteristics as well as time-varying aggregated sector characteristics do not confound the results.

Table 2. Effects of average input tariffs on economic activity

\begin{tabular}{l|l|l|l}
\hline \multicolumn{1}{c|}{ Dependent Variables: } & \multicolumn{1}{c|}{$(1)$} & \multicolumn{1}{c}{$(2)$} & \multicolumn{1}{c}{$(3)$} \\
\hline \multirow{2}{*}{ Log of average tariffs for Inputs } & \multicolumn{1}{c|}{ Log of employment } & \multicolumn{1}{c}{ Log of production } & \multicolumn{1}{c}{ Log of output per worker } \\
\cline { 2 - 4 } & $(0.056)$ & $-0.211^{* * *}$ & $-0.218^{* * *}$ \\
\hline Industry fixed effects & Yes & $(0.047)$ & $(0.077)$ \\
\hline Sector-year dummies & Yes & Yes & Yes \\
\hline Observations & 561 & Yes & Yes \\
\hline R-squared & 0.995 & 561 & 561 \\
\hline Adjusted R-squared & 0.994 & 0.979 & 0.989 \\
\hline
\end{tabular}

Note: Robust standard errors in parenthesis, ${ }^{* * *} p<0.01,{ }^{* *} p<0.05,{ }^{*} p<0.1$.

Source: OECD calculations based on data from OECD TiVA. 
A set of unreported robustness checks has been undertaken and is available on request. These include specifications in which the aggregate sector-year dummies are replaced by year dummies, the tariff measure enters with a one-year lag, and specifications where the assumption of a constant elasticity of labour productivity to input tariff changes is relaxed, obtaining similar results. Moreover, endogeneity concerns due to the simultaneity of tariffs and the error term because of protectionist motivations are somewhat mitigated in this set-up. A sudden decrease in output, employment or labour productivity in one sector, could lead to increases in sectoral import protection, leading to a downward bias of the coefficient estimate in any regression analysing the elasticity of economic activity to output tariffs. However, in this set up, the input tariff measure is a weighted average of tariffs across all economic sectors and is thus less likely to be simultaneously affected by shocks to the economic activity of one specific sector.

\section{A1.2. Simulation results}

To analyse the economy wide effects of a reduction in import protection for Brazil, the OECD METRO model is used to simulate a unilaterally decrease of currently applied tariffs and non-tariff measures in Brazil to the lowest levels among $\mathrm{G} 20$ countries and a reduction of services trade restrictions to the average level among G20 countries. Results suggest that lowering import barriers would reduce input and production costs, increase productivity, production and exports and lead to rising real wages for workers (Figure 2, in the main text of this paper). Exports increase by $14 \%$ and real GDP by $4 \%$. Consumer prices decline due to rising import competition and related associated productivity increases, which leads private consumption to increase by $6 \%$. This particularly benefits poorer households, as lower income households spend larger shares of their incomes on tradable goods such as food, home appliances, furniture and clothing, which are currently highly protected. Imports rise by $21 \%$.

Increasing import competition will also lead to the substitution of domestic demand towards imported inputs and final goods in some currently highly protected sectors (Table 3 ). These sectors will shed a minor share of their workforce, but rising competitive pressures and improved access to foreign inputs and technology will increase productivity and ultimately lead to rising production and exports in those sectors. Manufacturing sectors that would face stronger import competition are textile and wearing apparel, metal products, machinery and equipment, motor vehicles, electronic equipment and other manufacturing. Also in a number of services industries like finance, business services or transport services, moderate reductions in the workforce would go along with rising productivity, output and exports. At the same time, the model simulations also identify sectors where new employment opportunities will arise. These include food processing, agriculture, transport equipment, communication services and other services sectors such as utilities, retail, construction, tourism, education and health. 


\section{Table 3. Trade liberalisation will require some workers to move to jobs in other sectors}

Effects of a simulated unilateral reduction of tariff and non-tariff protection as well as services trade restrictions

\begin{tabular}{|c|c|c|c|}
\hline & $\begin{array}{l}\text { Changes in employment due to } \\
\text { trade liberalisation scenario } \\
\text { from METRO model (in \%) }\end{array}$ & $\begin{array}{l}\text { Changes in production due to } \\
\text { trade liberalisation scenario } \\
\text { from METRO model (in } \% \text { ) }\end{array}$ & $\begin{array}{l}\text { Changes in exports due to trade } \\
\text { liberalisation scenario from } \\
\text { METRO model (in \%) }\end{array}$ \\
\hline Cereal grains & 2.0 & 4.0 & 5.2 \\
\hline Other agriculture & 1.3 & 6.0 & 10.1 \\
\hline Oil seeds & 2.4 & 8.0 & 10.4 \\
\hline Dairy & 0.1 & 5.5 & 17.2 \\
\hline Natural resources & 2.0 & 3.0 & 3.7 \\
\hline Meats & 3.7 & 9.4 & 17.4 \\
\hline Food and beverage & 0.4 & 9.1 & 16.4 \\
\hline $\begin{array}{l}\text { Textile and wearing } \\
\text { apparel }\end{array}$ & -4.9 & 7.4 & 41.0 \\
\hline Mineral products & -2.8 & 5.1 & 14.9 \\
\hline Ferrous metals & -3.5 & 3.0 & 11.7 \\
\hline Nonferrous metals & 1.7 & 7.2 & 14.6 \\
\hline Metal products & -5.1 & 1.9 & 14.1 \\
\hline Motor vehicles and parts & -4.7 & 11.5 & 28.6 \\
\hline Transport equipment & 23.3 & 41.9 & 90.0 \\
\hline Electronic equipment & -5.2 & 5.9 & 29.3 \\
\hline Machinery and equipment & -10.6 & 0.0 & 31.1 \\
\hline Other manufacturing & -4.4 & 4.3 & 17.9 \\
\hline Transportation & -0.6 & 4.0 & 4.5 \\
\hline Communication & 0.6 & 3.4 & 2.5 \\
\hline Financial services & -0.8 & 1.9 & 1.6 \\
\hline Insurance & 0.1 & 1.8 & 0.4 \\
\hline Business services & -2.1 & 0.8 & 1.2 \\
\hline Other services & 0.5 & 2.3 & 0.2 \\
\hline Total & 0 & 3.91 & 14 \\
\hline
\end{tabular}

Note: The simulation reduces tariffs and ad-valorem equivalents for non-tariff measures unilaterally to the lowest level among G20 countries, and services trade restrictions to the average level across $\mathrm{G} 20$ countries. Total employment in each region in the METRO model is fixed and includes formal and informal workers as defined by the International Labour Organisation.

Source: OECD calculations based on the METRO model.

When only tariffs are unilaterally reduced to the lowest level among G20 countries, holding non-tariff measures and services trade restrictions constant, the simulated effects are somewhat weaker (Figure 22). Real GDP grows by $3.4 \%$. Private consumption and investment increase by $4.1 \%$ and $4.9 \%$, respectively, almost one third less than in the comprehensive liberalisation scenario. This is mainly because existing non-tariff measures and services trade restrictions protect domestic producers from international competition and keep prices for products and services higher than in the comprehensive liberalisation scenario. Domestic production costs fall less strongly, because many services are used as intermediate inputs, explaining why exports only increase by $8.3 \%$, compared to $14 \%$ in the comprehensive liberalisation scenario. Imports of intermediate inputs and final goods increase much less, as existing import barriers in services sectors keep prices of imported services high. 


\section{Figure 22. Lowering trade barriers boosts productivity, exports and private consumption}

Effects of a simulated unilateral reduction of tariffs, in percent

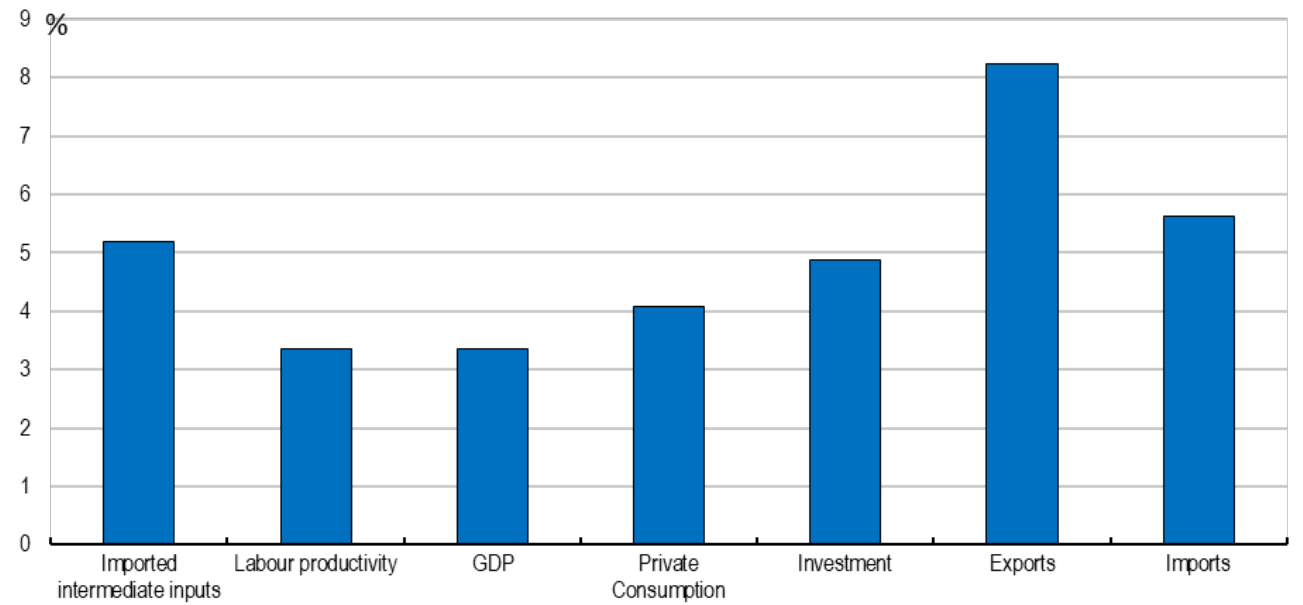

Note: Simulations are based on the OECD Metro model, which assumes full employment. The simulated policy change aligns tariffs unilaterally with the lowest level among G20 countries.

Source: OECD calculations based on the METRO model.

Unilaterally reducing import tariffs has similar effects on the reallocation of workers across sectors than in the comprehensive liberalisation scenario, although the magnitude of the reallocation effects is smaller. A similar set of manufacturing sectors reduces its workforce, which will need to find new jobs in the expanding agricultural, food processing and services sectors. An interesting difference, however, is that expanding services sectors significantly increase their supply of the domestic market and reduce their exports. This is because tariff reductions lead to productivity increases and rising production and exports in manufacturing sectors, which increases their demand for inputs from services sectors, such as communication, financial services, insurance and business services. As existing services trade restrictions keep prices of imported services high, this increasing domestic demand is satisfied by domestic services providers, which face relative increases in their domestic output prices. 
Table 4. Trade liberalisation will require some workers to move to jobs in other sectors

Effects of a simulated unilateral reduction of tariffs

\begin{tabular}{|c|c|c|c|}
\hline & $\begin{array}{l}\text { Changes in employment due to } \\
\text { trade liberalisation scenario } \\
\text { from METRO model (in \%) }\end{array}$ & $\begin{array}{l}\text { Changes in production due to } \\
\text { trade liberalisation scenario } \\
\text { from METRO model (in } \% \text { ) }\end{array}$ & $\begin{array}{l}\text { Changes in exports due to trade } \\
\text { liberalisation scenario from } \\
\text { METRO model (in \%) }\end{array}$ \\
\hline Cereal grains & 1.1 & 2.8 & 2.0 \\
\hline Other agriculture & 0.4 & 4.6 & 7.0 \\
\hline Oil seeds & 0.4 & 5.8 & 7.8 \\
\hline Dairy & 1.0 & 4.9 & 9.8 \\
\hline Natural resources & -0.5 & 0.7 & 0.2 \\
\hline Meats & 2.4 & 7.0 & 11.4 \\
\hline Food and beverage & 0.1 & 7.1 & 11.7 \\
\hline $\begin{array}{l}\text { Textile and wearing } \\
\text { apparel }\end{array}$ & -3.0 & 6.9 & 28.8 \\
\hline Mineral products & -3.9 & 2.3 & 8.7 \\
\hline Ferrous metals & -3.0 & 1.8 & 6.0 \\
\hline Nonferrous metals & -1.0 & 2.9 & 6.0 \\
\hline Metal products & -4.4 & 1.1 & 8.0 \\
\hline Motor vehicles and parts & -2.2 & 8.9 & 16.9 \\
\hline Transport equipment & 15.9 & 30.5 & 63.8 \\
\hline Electronic equipment & -3.1 & 5.9 & 20.5 \\
\hline Machinery and equipment & -3.3 & 5.3 & 22.6 \\
\hline Other manufacturing & -2.2 & 4.6 & 12.1 \\
\hline Transportation & 0.0 & 2.5 & 0.8 \\
\hline Communication & 1.3 & 2.1 & -2.0 \\
\hline Financial services & 1.1 & 1.5 & -2.7 \\
\hline Insurance & 0.3 & 0.8 & -2.8 \\
\hline Business services & 1.2 & 1.9 & -1.9 \\
\hline Other services & 0.0 & 1.0 & -2.4 \\
\hline Total & 0 & 2.9 & 8.3 \\
\hline
\end{tabular}

Note: The simulation reduces tariffs unilaterally to the lowest level among G20 countries. Total employment in the METRO model is fixed and includes formal and informal workers as defined by the International Labour Organisation.

Source: OECD calculations based on the METRO model. 


\section{A2. Identifying the effects of trade opening on regional employment and firm dynamics}

Apart from simulation methods using current data and modelling assumptions on economic structure, history can also provide insights into the likely effects of stronger integration going forward. Since the 1970s, trade policy in Brazil has seen only one significant inflection point, which is the visible reduction in trade barriers that occurred in the context of macroeconomic stabilisation in the 1990s.

Important for the following empirical analysis is that this policy change was unexpected, as a polarised political landscape and close presidential elections in 1989 had led to high uncertainty about the future course of economic policy (Cavgias et al., 2019[80]). Immediately after taking office in early 1990, the new president announced a schedule to reduce tariffs until 1995, mostly implemented ahead of the initially set dates. The size of tariff reductions by sector was mostly determined by pre-liberalisation tariff levels, as the objective was to lower and equalise import protection across sectors to reduce distortions of relative prices (Dix-Carneiro and Kovak, 2017 ${ }_{[42]}$ ). Thus, lobby pressure motivated by industry performance in the pre-liberalisation period had little influence on the size of the industry specific tariff reductions.

This study uses this exogenous shock in trade protection to analyse its effects on employment and firm dynamics using the local labour market approach (Autor, Dorn and Hanson, 2013[43]; Topalova, 2010[44]; Dix-Carneiro and Kovak, 2017 ${ }_{[42]}$ ). The fact that during the 1990s a range of different macroeconomic and structural policies were implemented simultaneously makes it difficult to draw conclusions from macroeconomic or sectoral data. The local labour market approach is one frequently applied solution to this identification problem. Local labour markets differ with respect to their industry structure and thus their exposure to trade liberalisation, but are subject to the same national institutions and macroeconomic shocks. Together with the fact that migration of workers and firms between local labour markets is costly, it is possible to disentangle the effects of trade opening on employment and firm dynamics by focusing on different trajectories across regions in time. The analysis exploits differences across micro regions as defined by the Brazilian statistics institute (IBGE), which combine municipalities that are well connected by transport infrastructure, have common production structures as well as similar socio-economic and geographic characteristics (Dix-Carneiro and Kovak, 2017 ${ }_{[42]}$ ).

\section{A2.1. Data}

Data on employment, wages and other socio-economic characteristics of workers as well as on firm dynamics come from the matched employer-employee administrative dataset collected by the former Brazilian Labour Ministry (MTB or MTE), the Relação Anual de Informações Sociais (RAIS). It covers the universe of formal sector jobs throughout 31 years, from 1985 until 2015, and contains information on employees' characteristics - such as gender, wage, age, occupation, and education level - and on employers' characteristics - such as number of employees, industry of activity as well as firm entry and exit. Data quality of RAIS is high because it is the basis for large-scale public benefit programs for workers. As employers face high fines for non-compliance, both workers and firms have incentives to provide correct information.

Based on information on the municipality where the job match is located, we create a dataset that maps RAIS microdata into a panel of 490 local labour markets from 1985 until 2015. Our definition of local labour markets follows the one from the Brazilian national statistics institute (IBGE) which aggregates municipalities that are well connected by transport infrastructure, have common production relations as well as similar socio-economic and geographic characteristics into micro regions, which defined for the period 1989 until 2017. This definition of micro regions has been extensively used as a proxy for local labour markets in Brazil (Dix-Carneiro and Kovak, 2017 [42]; Dix-Carneiro, Soares and Ulyssea, 2018[81]; Hirata and Soares, 2016[82]; Costa, Garred and Pessoa, 2016[83]). As RAIS data already starts in 1985 and municipality definitions have changed until 1989, we use available geo-location data to aggregate IBGE 
micro regions that shared one or more municipal areas before 1989. This resulted in the construction of 490 time-consistent labour markets throughout our sample period. Oln the empirical analysis, we exclude nine micro-regions that showed zero employment in tradable sectors at the start of the trade liberalisation in 1990.

The following variables on employment and firm dynamics are created at the micro region level for each year from 1985 until 2015. Total employment is defined as the number of active job matches on 31 December of each year. Job creation is the sum of job matches created throughout the year, regardless of whether they remain active by the end of the year. Job Destruction is constructed similar to job creation, but for job matches that have been destroyed. The total wage bill is defined as the sum of all monthly wages paid to workers employed in December of each year, measured in 2015 prices. To transform nominal wages into real wages at 2015 prices, RAIS information expressing wages in multiples of the national minimum wage on 31 December of each year is combined with a time-series on national minimum wages from 1980 until 2015 from the National Statistics Institute (IBGE). Real average monthly wages per worker are defined as the total wage bill divided by the number of employees in the micro region.

Additional variables capturing employment dynamics at the micro region level comprise the average age of workers employed in December of each year, the share of female workers in December of each year as well as net job creation, which is defined as the difference in total employment between the current and the previous year. The variable age of workers is only available in RAIS from the year 1994 onwards. In addition, employment and wage variables as well as job creation and destruction are also constructed for different categories of workers' skill levels, as defined by education or occupation categories. Education categories are defined as high skilled (completed tertiary education), medium skilled (completed secondary education), and low skilled (less than upper secondary education). Occupation categories are defined as high-skilled white-collar (ISCO88 groups 1-3), low-skilled white-collar (ISCO88 groups 4-5), high-skilled blue-collar (ISCO88 groups 6-7), and low-skilled blue-collar (ISCO88 groups 8-9). The wage bill share of a skill category of workers is defined as the total wage bill for this category of workers divided by the total wage bill for all workers in the micro region. The employment share captures the share of the specific skill category of workers in total employment of the micro region. Information on the economic sector of the job match is also used to calculate sector specific employment at the micro region level.

To analyse firm dynamics at the micro region level, the following variables have been created. The number of entering plants is defined as the number of plants being active in the micro region that have not been active in the previous year. The number of exiting plants comprises plants that are active in the current year, but not in the next year. Entry and exit rates are defined as the number of entering and exiting plants divided by the total number of active plants in the current year, respectively. In addition, the number of incumbent plants comprises plants that are active in the micro region in the current and the previous year. The average size of plants is defined as total employment divided by the number of active plants. Similarly, the average size of entering and incumbent plants is defined as total employment in entering and incumbent plants divided by the total number of entering and incumbent plants, respectively. The average age of plants is the average over the age of single plants, defined as the period from the current year minus the first year they appeared in RAIS.

Additional data on GDP, value added in agriculture, manufacturing and services sectors, and the total population at the municipal level comes from the Brazilian National Institute of Statistics (IBGE). GDP data is available for the years 1985 and 1996 until 2015, but sectoral value added data only from 2010 until 2015. Population data is available for 1980 and from 1991 until 2017. Data on the economically active population by age groups as well as the age structure of the population at the municipal level comes from the National Census and is available for the years 1991, 2000 and 2010. Data on informal workers by municipality comes from the National Census, but is only available for the years 2000 and 2010 . In addition, the analysis also uses data on the structure of municipal revenues and expenses from 1985 until 2015 from the research institute IPEA. The municipal data is aggregated to the micro region level using the mapping described above. 


\section{Measuring the exposure of local labour markets to the trade liberalisation of the 1990s}

To measure the exposure of local labour markets to the tariff reductions from 1990-1995, this study follows the empirical literature and uses regional employment shares by industry at the start of the liberalisation period to weight the national tariff reductions and map them into micro regions (Topalova, 2010[44]; DixCarneiro and Kovak, 2017 ${ }_{[42]}$; Bartik, 1991[84]). Precisely, for each micro region $m$, and tradeable industry $i$ with employment share $\lambda_{m, i}$ and tariff $T_{i}$, local tariff shocks $T R_{m, 95-90}$ are defined as:

$$
T R_{m, 1995-1990}=-\sum_{i}\left[\frac{\lambda_{m, i, 1990}}{\sum_{j \neq i} \lambda_{m, j, 1990}}\left(\ln \left(1+\tau_{i, 1995}\right)-\ln \left(1+\tau_{i, 1990}\right)\right)\right]
$$

Note that a tariff cut will have a positive sign, making interpretation of the results more intuitive. Differently from Dix-Carneiro and Kovak (2017), who use formal plus informal employment per industry and micro region to weight national tariff cuts, this study only uses formal sector employment to construct a regional measure of trade exposure and to analyse its effects on formal sector employment and firm dynamics at the micro region level. Importantly, non-tradable sectors are excluded in the computation of the weights, as the regional employment share is defined as total employment in each tradeable industry as a share of total employment in all tradeable industries. This assumes that non-tradeable prices co-move with tradeable prices affected by the tariff cuts, an assumption that has been shown to hold true in the context of Brazil and elsewhere (Dix-Carneiro and Kovak, 2017[42]; Kovak, 2013[85]; Broxterman and Larson, 2020[86]).

Consistent with the previous literature, data on tariff reductions from 1990 until 1995 are obtained from Kume et al. (2003), who collected tariff data from 1987 until 1999 at the "Nivel 80" level, a former national accounts classification used by the Brazilian National Statistics Institute (IBGE) comprising 53 industry classes (Dix-Carneiro, Soares and Ulyssea, 2018[81]; Kovak, 2013[85]; Menezes-Filho and Muendler, $2011_{[87] ;}$ Kume, Piani and Braz de Sousa, 2003[88]; Dix-Carneiro and Kovak, 2017[42]). As employment data from RAIS contains varying economic sector classifications across years, compatibility between years for the whole sample period from 1985 until 2015 is only possible at the two-digit IBGE subsector level, which comprises 25 economic sectors. The matching algorithm between the tariff classification and the two-digit IBGE sub-sector classification uses several steps following the literature and is available upon request (Dix-Carneiro and Kovak, 2017[42]; Menezes-Filho and Muendler, 2011[87]).

The resulting index of trade exposure of micro regions is presented in Figure 6. Micro regions with a darker shade experienced a stronger exposure to the tariff cuts from 1990 until 1995, because a larger share of their formal employment was in industries that experienced larger tariff cuts. The highest percentile of micro regions experienced tariff cuts of 20 percentage points and the lowest percentile tariff cuts of 6 percentage points (Table 5). The difference between the tariff cuts of micro regions in the $90^{\text {th }}$ percentile compared to the $10^{\text {th }}$ percentile is around 10 percentage points. 


\section{Table 5. Tariff reductions by percentiles of micro regions}

Tariff reductions 1990-1995 weighted by industry employment shares in micro regions (in percentage points divided by 100)

\begin{tabular}{l|l}
\hline \multicolumn{1}{c|}{ Percentiles of trade exposure of micro regions } & \multicolumn{1}{c}{ Average tariff reductions (in percentage points) } \\
\hline $10^{\text {th }}$ & 0.06 \\
\hline $20^{\text {th }}$ & 0.09 \\
\hline $30^{\text {th }}$ & 0.11 \\
\hline $40^{\text {th }}$ & 0.12 \\
\hline $50^{\text {th }}$ & 0.13 \\
\hline $60^{\text {th }}$ & 0.14 \\
\hline $70^{\text {th }}$ & 0.14 \\
\hline $80^{\text {th }}$ & 0.15 \\
\hline $90^{\text {th }}$ & 0.16 \\
\hline $100^{\text {th }}$ & 0.20 \\
\hline
\end{tabular}

Note: Micro regions are defined by the Brazilian national statistics institute (IBGE) as an aggregation of municipalities that are well connected by transport infrastructure, have common production structures as well as similar socio-economic and geographic characteristics. Regional trade exposure is computed as the weighted average of tariff cuts from 1990-1995, with industry employment shares per micro region as weights.

Source: OECD calculations based on RAIS data and data from Kume et al. (2003).

\section{A2.2. Empirical methodology}

To gauge the effects of trade exposure on regional firm dynamics and labour market outcomes across time, the analysis uses a long-difference estimator (Dix-Carneiro and Kovak, 2017[42]). The following equation is separately estimated for each year during the liberalisation period, $t=1990,1994$, and the postliberalization period, $\mathrm{t}=1995, \ldots, 2015$, as well as for several dependent variables y using OLS estimation:

$$
\Delta y_{m, s, t-1989}=\theta_{t} T R_{m, s, 1995-1990}+\delta_{s, t}+\gamma_{t} X_{m, s, t}+\varepsilon_{m, s, t}
$$

Where $\mathrm{m}$ stands for micro region, $\mathrm{s}$ for the state where the micro region is located and $t$ for the year of the observation. The dependent variable enters in differences between year $t$ and the pre-liberalisation year 1989. The independent variable of interest is the local tariff shock TR at the micro region level, where a stronger tariff reduction translates into a higher positive value of TR. The coefficient $\theta_{t}$ measures the difference in the trends of the dependent variables from year 1989 until year $t$ between regions that experienced higher tariff reductions from 1990 until 1995 and regions with lower tariff reductions. Specifically, as the difference in tariff reductions between the $90^{\text {th }}$ and the $10^{\text {th }}$ percentile of micro regions is 0.1 (or 10 percentage points), results are interpreted using this comparison as the benchmark.

The dependent variable (y) can take two forms: the logarithm of levels of a variable at the micro region or the share of a skill category of workers in the total wage bill or employment in the micro region. If the dependent variable is measured as logarithm of levels, a $\mathrm{K}$ percentage point difference in trade exposure between micro regions translates into a $\theta_{t} \mathrm{~K} / 100$ percentage point larger or smaller (if $\theta_{t}$ is negative) proportional growth in the dependent variable from 1989 until year $t$. If the dependent variable is the wage or employment share of a skill category of workers, a $\mathrm{K}$ percentage point difference in trade exposure between micro regions translates into a $\theta_{t} \mathrm{~K} / 100$ percentage point larger (or smaller) employment or wage share in year $\mathrm{t}$. In addition, a third type of dependent variable is used instead of $\Delta \mathrm{y}$, which is the cumulative sum of entering (or exiting) firms at the micro region level from 1989 until year $t$, divided by the total number of plants in the micro region in year $\mathrm{t}$. In this case, a $\mathrm{K}$ percentage point difference in trade exposure between micro regions translates into a $\theta_{t} \mathrm{~K} / 100$ percentage point larger (or smaller) cumulative entry (or exit) rate between 1989 and year $t$. 
All regressions include state-year fixed effects $\delta_{\mathrm{s}, \mathrm{t}}$, for the 26 Brazilian states, which due to the differenced nature of the dependent variable control for all time-varying omitted variables at the state level. Thus, identification of the coefficient $\theta_{t}$ relies exclusively on variation of the dependent and independent variables across micro regions within the same state. Economic, institutional or social changes that are the same for all micro regions within one state do not confound the results of this study. In addition, a set of time-varying control variables at the micro region level $\left(\mathrm{X}_{\mathrm{m}, \mathrm{s}, \mathrm{t}}\right)$ is included. This comprises the change in the share of women in the workforce between year $t$ and year 1989, the change in the average age of workers between year $t$ and year 1994 as well as the change in the logarithm of total population in the micro region between year $t$ and year 1991. As the age of workers and total population are not available from year 1989 on, these control variables are only included in robustness checks. To account for the different size of micro regions in another way, equation (3) is also estimated using total population as weights, giving larger micro regions more weight in the regressions. All these different specifications confirm the robustness of our main results. Finally, heteroscedasticity robust standard errors are used and state-year dummies control for any clustering of standard errors at the state level.

A consistent estimation of the coefficient of interest $\theta_{t}$ requires the absence of any time-varying idiosyncratic and unobserved determinants of the dependent variable at the micro region level that are correlated with to the local tariff cuts, conditional on the state-year fixed effects and the included control variables. This assumption could be violated, for instance, if tariff cuts in the early 1990s had been influenced by lobbying motivated by the economic performance of micro regions before the liberalisation period, which is probably correlated with economic performance after the trade liberalisation period. However, due to the unexpected and centralised character of the decision to reduce tariffs, as described above, it is very unlikely that political pressure from certain micro regions might have influenced the size of tariff reductions. Moreover, as the objective of the tariff reductions was to lower and equalise import protection across sectors to reduce distortions of relative prices, the size of tariff reductions was mostly determined by pre-liberalisation tariff levels (Dix-Carneiro and Kovak, 2017[42]). Thus, lobby pressure motivated by industry performance in the pre-liberalisation period also had little influence on the size of the industry specific tariff reductions.

Nevertheless, to address these concerns about possible endogeneity of local tariff cuts to economic performance in the pre-liberalisation period empirically, pre-trends of the dependent variable for the five pre-liberalization years 1985-1989 are included as additional control variables in equation (3). The results of this specification confirm the robustness of our main results in line with a large literature that has emphasised the exogenous nature of the Brazilian trade liberalisation period (Dix-Carneiro and Kovak, 2017[42]; Menezes-Filho and Muendler, 2011[87]; Kovak, 2013[85]; Goldberg and Pavcnik, 2003[89]).

Another important assumption for the identification of the coefficient of interest is the assumption of reduced mobility of workers and firms between micro regions. The empirical literature has shown that the geographic mobility of workers, and in particular of low-skilled and older workers, is often severely limited by the low quality of transport infrastructure, housing market distortions, job search costs, social costs of moving families or a limited ability to learn and adapt to new social contexts (Hyman, 2018[90]; Autor et al., 2014[20]; Gathmann, Helm and Schönberg, 2018[91]). As Brazil is a big country with high average distances between micro regions as well as low quality of transport infrastructure and public transportation, migration costs for workers and firms are particularly high. Many administrative barriers to internal trade including different tax systems across states that discriminate against input sourcing from other states also increase the costs for relocating firms. Nevertheless, to test for the presence of migration between micro regions in response to the local trade shocks, equation (3) is estimated using population or working population as the dependent variable. As described below, these robustness checks indicate that migration between micro regions cannot explain our main results. 


\section{Identifying the effects of local training provision on regional employment trajectories}

To investigate how training can mitigate adjustment costs for workers, the empirical analysis combines the constructed panel data at the micro region level with unique micro data on training enrolment and completion from Brazils PRONATEC program. PRONATEC was a government-led initiative that strongly expanded the offer of short-term vocational training courses to low-skilled workers and unemployed individuals across the whole country from 2011 until 2018.

The data used for this study is an extract from the National Information System of Vocational Education ("Sistema Nacional de Informações da Educação Professional e Tecnológica", SISTEC), and includes all individuals who enrolled in a vocational education training course, organised as part of the PRONATEC programme, from 2011 to 2015. It covers all regions and municipalities in Brazil and includes information on the training provider, the location of the training, the area of study, the total number of hours of training classes, the delivery mode (distance learning or face-to-face) and the PRONATEC partner who requested the training course. It also contains information on the socio-economic background of participating individuals.

It is important for the empirical analysis that although the Ministry of Education coordinated the training programme, other ministries could request training courses for specific localities and select training participants (OECD, 2018[51]). There were no guidelines to collaborating ministries on how to identify training needs in their respective areas of intervention. Most ministries organised their requests centrally without consulting regional and local authorities. This resulted in many training courses not meeting the skills required by recruiting firms in local labour markets and not addressing individuals' actual re-skilling needs (O'Connell et al., 2017[92]; OECD, 2018[51] $)$.

The Ministry of Industry (MDIC) was the only PRONATEC partner that developed a systematic method to assess and anticipate skills needs before submitting course requests. Their method explicitly took into account the location, scale and skill content of firms' training needs. During the first years of the program, from 2013 until 2015, staff at MDIC contacted firms in different sectors and locations informally to enquire about their training needs. As a result, training courses demanded by MDIC were more demand-driven, as opposed to the courses from other collaborating ministries (O'Connell et al., 2017 [53]; OECD, 2018 $_{[51]}$ ). At a later stage, MDIC developed a web platform called "SuperTec" where employers could register and provide information regarding their skills needs and the volume of training desired, which significantly increased the efficiency of the information collection procedure.

For the empirical analysis, information on the number of hours of provided training classes is aggregated at the micro region level for the years 2011 until 2015. To single out training that targeted local skill demands, the analysis separates between training courses offered by MDIC and courses offered by other Ministries. To measure the treatment of workers with specific training courses within micro regions, the pooled number of training class hours from 2011 until 2015 as well as the cumulative sum of training class hours are constructed. Two additional variables are constructed by dividing the pooled number of training hours as well the cumulative sum of hours by the number of workers in the micro region. As training classes requested by MDIC only started in 2013, for this type of training all variables are constructed from 2013 until 2015.

To investigate whether training has influenced the effects of increasing trade exposure on employment growth trajectories in micro regions, the following equation extends equation (3) with a variable for training provision $z$ and is separately estimated for each year t from 2011 until 2015 using OLS estimation. For MDIC training, which has started in 2013, the equation is estimated from 2013 onwards.

$$
\begin{aligned}
\Delta y_{m, s, t-1989}= & \theta_{t} T R_{m, s, 1995-1990}+\beta_{t} T R_{m, s, 1995-1990} * z_{m, s, t}+\alpha_{t} z_{m, s, t}+\delta_{s, t}+\gamma_{t} X_{m, s, t} \\
& +\varepsilon_{m, s, t}
\end{aligned}
$$


The measure for local tariff reduction TR is interacted with the measure for local training provision $z$, and the dependent variable $y$ stands for the log of employment. The coefficient $\beta_{t}$ indicates whether the effect of local tariff reductions on employment growth has been mitigated or amplified by training provision in the micro region from $t=2011, \ldots, 2015$. As training courses requested by MDIC were targeting local skill demands in terms of scale and content of courses, past employment trends and other characteristics of the micro region, which are correlated with the dependent variable, might have influenced the amount of training hours provided to the micro region. This would lead to an inconsistent estimation of the coefficient $\beta_{t}$ in equation (4), as the error term $\varepsilon$ would be correlated with the independent variable of interest $z$.

One argument for why this endogeneity issue might play a minor role in our analysis is that in the first years of the MDIC training program, which started in 2013, staff at MDIC were initially contacting firms in different sectors and locations in an informal and somewhat random way to inquire about their training needs. Thus, compared to the later stage of the program, where all employers could register online and provide information regarding their skills needs and the volume of training desired, from 2013-2015 not all micro regions with large potential for future employment growth have been contacted by MDIC. Moreover, the final decision to open a requested training course in a specific locality was made by the Ministry of Education, which had other objectives than MDIC, focusing more on the general provision of education opportunities for disadvantaged parts of the population. Thus, it is reasonable to assume that a considerable share of micro regions with strongly increasing employment opportunities and skill needs has not been provided with MDIC training courses from 2013-2015, which mitigates the endogeneity concerns described above.

Nevertheless, to address this endogeneity issue more formally, robustness checks include possible determinants of the training hour allocation to micro regions in the vector of control variables $\mathrm{X}$ in equation (4). In particular, GDP, the number of employees, and agricultural value added by micro region are included with their pre-treatment levels of 2011 and their pre-trends from 2010 until 2011. As the decisions for the first round of training requested by MDIC were made in 2012, pre-trends and levels refer to the time prior to 2012. These variables are significantly correlated with the provided number of training hours that were requested from MDIC, except for the pre-trend in formal employment (Table 6). Micro regions received more hours of MDIC training from 2013-2015, if they had been exposed to larger tariff reductions in the 1990s, had higher employment, experienced higher GDP growth rates in the previous year or increased the share of manufacturing and services in value added (ceteris paribus). Also, training hours were higher in poorer regions, as measured by GDP (holding constant employment) or the share of agriculture in total GDP. Results presented further below show that the main findings of our analysis are robust to the inclusion of these pre-treatment controls. 
Table 6. Determinants of training provision at the micro region level

\begin{tabular}{l|l}
\hline & \\
\hline Dependent variable: & $\begin{array}{c}\text { Number of hours of MDIC training classes per micro region and for } \\
\text { the period 2013-2015 (in thousand) }\end{array}$ \\
\hline Tariff reductions at the micro region level (in percentage points) & $0.143^{* * *}$ \\
\hline & $(4.898)$ \\
\hline GDP growth from 2010 to 2011 (in \%) & $0.044^{*}$ \\
\hline Employment growth from 2010 to 2011 (in \%) & $(0.023)$ \\
\hline & 0.010 \\
\hline Growth in agricultural value added from 2010 to 2011 (in \%) & $(0.012)$ \\
\hline & $-0.023^{* *}$ \\
\hline GDP in 2011 (in billion Reais) & $(0.009)$ \\
\hline & $-0.146^{* * *}$ \\
\hline Employment in 2011 (in thousands) & $(0.051)$ \\
\hline & $0.033^{* * *}$ \\
\hline Agricultural value added in 2011 (in million) & $(0.007)$ \\
\hline & $0.003^{* *}$ \\
\hline Observations & $(0.001)$ \\
\hline R-squared & 479 \\
\hline Adjusted R-squared & 0.483 \\
\hline
\end{tabular}

Note: Robust standard errors in parentheses, ${ }^{* * *} p<0.01,{ }^{* *} p<0.05,{ }^{*} p<0.1$

Source: OECD calculations.

As an additional robustness check, a propensity score estimator is used to investigate whether micro regions whose workers have been provided with MDIC training classes from 2013 until 2015 have indeed had a higher employment growth until 2015 compared to regions that have not been provided with such training classes. As trade exposure as well as pre-trends and pre-treatment levels of GDP, employment and agricultural value added are significant determinants of the treatment of micro regions with MDIC training courses (Table 6), the matching estimator uses these observable variables to construct pairs of similar micro regions which different treatment status (Cameron and Trivedi, 2005[93]). By averaging the difference in outcomes between treated and untreated micro regions within pairs across the sample, it computes the average treatment effect of MDIC training hours on employment growth in micro regions. The results of the matching estimator are similar to the results from the estimation of equation (4), which emphasises the robustness of our findings.

\section{A2.3. Results}

Although formal employment has increased strongly since the 1990s, employment growth has generally been weaker in regions that were more exposed to import competition (Table 7). For example, a micro region that experienced a 10 percentage point larger tariff cut in the 1990s, approximately the difference in tariff reductions between the 90th and the 10th percentile of micro regions (Table 5), showed a $45 \log$ point (around 57 percentage points) lower employment growth between 1990 and 2015 (column 7 of Table 7). For the interpretation of the results in this paper, trade affected and less trade affected micro regions refer to the comparison between micro regions from the $90^{\text {th }}$ and the $10^{\text {th }}$ percentile of regional trade exposure. To simplify the argumentation, results presented here interpret log point differences as percentage point differences as done in related literature (Dix-Carneiro and Kovak, 2017 ${ }_{[42]}$ ). This is an approximation which is valid only for small values, which is why in this technical background paper percentage point changes corresponding to the estimated log point changes are presented (Dix-Carneiro, Soares and Ulyssea, 2018[81]). 
The main results are robust to the inclusion of additional covariates such as changes in total population, workforce age and a pre-trend of the outcome variable before the start of the liberalisation period (columns $2,4,6$, and 8 of Table 7). Weighting the equation (3) by population size of micro regions gives very similar results available upon request. For the figures in this paper, equation (3) has been estimated for each year from 1990 until 2015, but to improve readability of tables in this section, only results for the years 2000, 2005, 2010 and 2015 are presented.

\section{Table 7. Employment growth has been weaker in regions more exposed to trade liberalisation}

Differences in employment growth between regions more and less exposed to trade opening

\begin{tabular}{|c|c|c|c|c|c|c|c|c|}
\hline \multirow[t]{2}{*}{ Year of the observation $(\mathrm{t})$} & \multicolumn{2}{|c|}{2000} & \multicolumn{2}{|c|}{2005} & \multicolumn{2}{|c|}{2010} & \multicolumn{2}{|c|}{2015} \\
\hline & (1) & (2) & (3) & (4) & (5) & (6) & (7) & (8) \\
\hline & \multicolumn{8}{|c|}{ Dependent variable: Differences in log employment (between year $t$ and 1989) } \\
\hline \multicolumn{9}{|l|}{ Independent variables } \\
\hline \multirow{2}{*}{$\begin{array}{l}\text { Local tariff reductions (in percentage } \\
\text { points divided by 100) }\end{array}$} & $-2.823^{\star * *}$ & $-3.251^{* * *}$ & $-3.879^{* * *}$ & $-4.262^{* * *}$ & $-3.969^{* * *}$ & $-4.464^{* * *}$ & $-4.472^{\star * *}$ & $-5.002^{* \star *}$ \\
\hline & $(0.556)$ & $(0.504)$ & $(0.668)$ & $(0.645)$ & (0.671) & $(0.631)$ & $(0.700)$ & $(0.657)$ \\
\hline \multirow{2}{*}{$\begin{array}{l}\text { Difference in the share of women in the } \\
\text { workforce (from year t to 1989) }\end{array}$} & 0.678 & 0.359 & 0.759 & 0.437 & 0.303 & -0.170 & 0.074 & -0.280 \\
\hline & $(0.454)$ & $(0.374)$ & $(0.478)$ & $(0.443)$ & $(0.451)$ & $(0.412)$ & $(0.427)$ & $(0.399)$ \\
\hline \multirow{2}{*}{$\begin{array}{l}\text { Difference in the average age of the } \\
\text { workforce (from year t to 1994) }\end{array}$} & & -0.016 & & -0.038 & & $-0.040^{*}$ & & $-0.061^{* * *}$ \\
\hline & & $(0.026)$ & & $(0.025)$ & & $(0.022)$ & & $(0.024)$ \\
\hline \multirow{2}{*}{$\begin{array}{l}\text { Difference in the log of total population } \\
\text { (from year t to 1991) }\end{array}$} & & $0.847^{\star \star \star}$ & & $0.400^{*}$ & & $0.669^{\star \star \star}$ & & $0.664^{* \star *}$ \\
\hline & & $(0.321)$ & & $(0.207)$ & & $(0.174)$ & & $(0.156)$ \\
\hline \multirow{2}{*}{$\begin{array}{l}\text { Pre-trend in the outcome (difference in log } \\
\text { of employment between } 1989 \text { and } 1985\end{array}$} & & $-0.332^{\star * *}$ & & $-0.490^{* * *}$ & & $-0.571^{\star \star *}$ & & $-0.587^{* \star \star}$ \\
\hline & & $(0.077)$ & & $(0.116)$ & & $(0.120)$ & & $(0.125)$ \\
\hline State-year fixed effects & Yes & Yes & Yes & Yes & Yes & Yes & Yes & Yes \\
\hline Observations & 481 & 481 & 481 & 481 & 481 & 481 & 481 & 481 \\
\hline R-squared & 0.366 & 0.432 & 0.453 & 0.512 & 0.469 & 0.551 & 0.471 & 0.560 \\
\hline Adjusted R-squared & 0.327 & 0.393 & 0.419 & 0.478 & 0.436 & 0.520 & 0.438 & 0.529 \\
\hline
\end{tabular}

Note: Robust standard errors in parentheses; ${ }^{* * *} p<0.01,{ }^{* *} p<0.05,{ }^{*} p<0.1$.

Source: OECD calculations based on RAIS data.

These average effects hide considerable heterogeneity across micro regions that have experienced large tariff cuts in the 1990s. Some of them have performed well, with strong employment and output gains recorded in micro regions located in poorer states such as Pernambuco, Maranhão, Alagoas and Rio Grande do Norte (OECD analysis). Moreover, the estimates in (Table 7) only show relative differences in employment growth between regions. Employment growth has on average been positive in micro regions with strong tariff reductions, but with lower growth rates than in micro regions with smaller tariff reductions (Figure 23). 


\section{Figure 23. Employment growth has been positive across all micro regions}

Average employment growth in micro regions by percentile of tariff exposure (from 1989 until 2015)

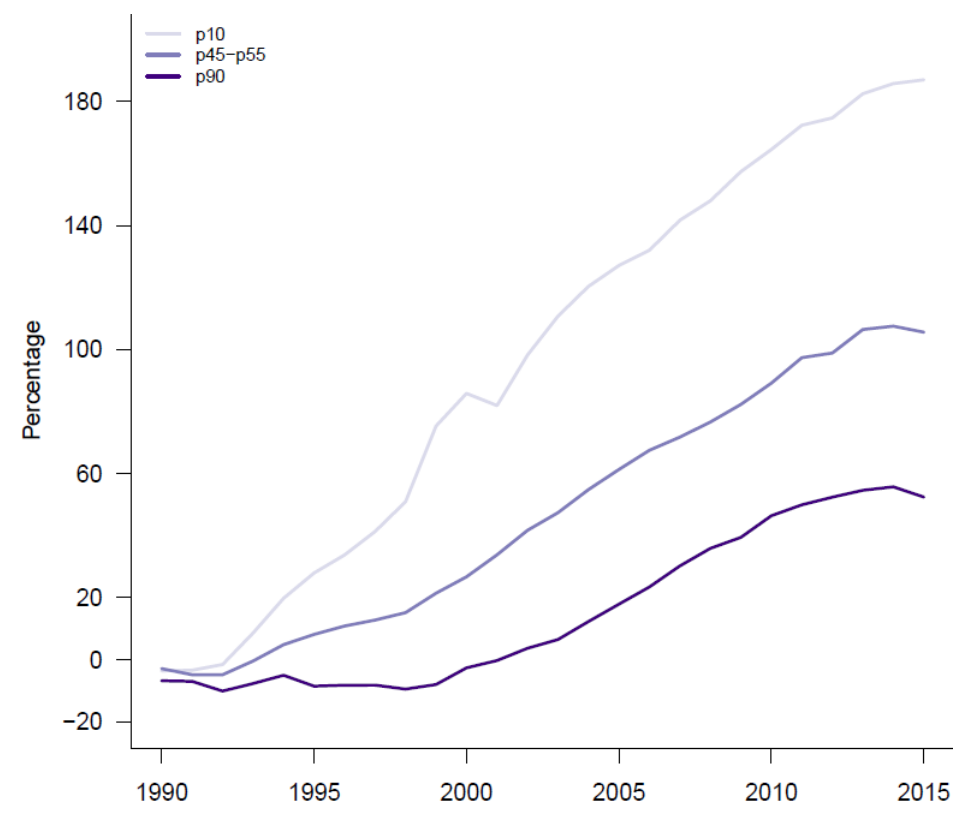

Note: Average employment growth across micro regions within one percentile of the trade exposure distribution has been calculated using employment in 1990 as weights.

Source: OECD calculations based on RAIS data.

The results for other dependent variables are presented in the form of graphs. Although employment growth was weaker in regions more exposed to trade liberalization, firm entry and exit rates as well as turnover increased. The average size of entering firms rose, the one of incumbents decreased, and real wages grew, signalling that trade opening invigorated the forces of creative destruction. Especially low skilled workers suffered from employment losses; the share of medium skilled jobs expanded the most. All these results are robust to the inclusion of additional control variables or weighting the regressions by population size of micro regions. Detailed results tables can be obtained from the authors upon request.

\section{Training targeted to local skill demands mitigates adjustment costs for workers}

Combining the constructed panel dataset at the micro region level with data from a large-scale training programme, this study finds that only this vocational training that has been requested by MDIC and was aligned with local skill demand has been effective to reduce the negative employment effects of rising import competition (Table 8). Trade-affected micro regions that have raised the supply of vocational training courses targeted to local skill demands by an average of 10,000 classroom hours from 2013 to 2015 have narrowed the gap in employment growth with respect to less trade-exposed regions by more than $50 \%$ (columns 1 until 3 of Table 8 ). In 2015, employment growth in these regions has only been 18 log points (20 percentage points) lower than in micro regions less affected by tariff reductions, whereas trade affected micro regions without MDIC training courses had 46 log points (58 percentage points) lower employment growth. As a class comprises on average 25 trainees, 10,000 classroom hours correspond to 250,000 subsidised training hours. The median micro region had 25,000 employees in 2012. Other types of training courses, which had not specifically targeted skill demands in local labour markets, have had much smaller effects on employment growth (columns 4 until 6 of Table 8). 
Table 8. Training targeted to local skill demands mitigates adjustment costs for workers

Differences in employment growth between regions more and less exposed to trade opening

\begin{tabular}{|c|c|c|c|c|c|c|}
\hline \multirow[t]{2}{*}{ Year of the observation $(t)$} & \multicolumn{3}{|c|}{ MDIC training } & \multicolumn{3}{|c|}{ Other types of training } \\
\hline & (1) & (2) & (3) & (4) & (5) & (6) \\
\hline & 2013 & 2014 & 2015 & 2013 & 2014 & 2015 \\
\hline & \multicolumn{6}{|c|}{ Dependent variable: Differences in log employment (between year $t$ and 1989) } \\
\hline \multicolumn{7}{|l|}{ Independent variables } \\
\hline \multirow{2}{*}{$\begin{array}{l}\text { Local tariff reductions (in percentage } \\
\text { points divided by 100) }\end{array}$} & $-4.263^{\star * *}$ & $-4.565^{\star * *}$ & $-4.612^{\star \star *}$ & $-4.557^{\star \star \star}$ & $-4.943^{* * *}$ & $-4.905^{\star \star *}$ \\
\hline & $(0.693)$ & $(0.666)$ & $(0.676)$ & $(0.812)$ & $(0.783)$ & $(0.793)$ \\
\hline \multirow{2}{*}{$\begin{array}{l}\text { Interaction of local tariff reductions and } \\
\text { training class hours until } 2015 \text { (in 10,000) }\end{array}$} & $2.377^{\star \star}$ & $2.632^{\star *}$ & $2.776^{* *}$ & $0.156^{* \star *}$ & $0.170^{\star \star *}$ & $0.161^{* * *}$ \\
\hline & $(1.089)$ & $(1.098)$ & $(1.168)$ & $(0.056)$ & $(0.057)$ & $(0.058)$ \\
\hline \multirow{2}{*}{$\begin{array}{l}\text { Training class hours } \\
\text { until } 2015 \text { (in 10,000) }\end{array}$} & $-0.395^{\star *}$ & $-0.428^{* * *}$ & $-0.458^{* * *}$ & $-0.030^{\star * *}$ & $-0.032^{* * *}$ & $-0.032^{\star \star \star}$ \\
\hline & $(0.159)$ & $(0.159)$ & $(0.168)$ & $(0.008)$ & $(0.008)$ & $(0.008)$ \\
\hline Control variables & Yes & Yes & Yes & Yes & Yes & Yes \\
\hline State-year fixed effects & Yes & Yes & Yes & Yes & Yes & Yes \\
\hline Observations & 479 & 479 & 479 & 479 & 479 & 479 \\
\hline R-squared & 0.590 & 0.596 & 0.602 & 0.620 & 0.625 & 0.631 \\
\hline Adjusted R-squared & 0.553 & 0.559 & 0.566 & 0.586 & 0.591 & 0.597 \\
\hline
\end{tabular}

Note: Equation (4) is estimated for each year from 2013 until 2015, as MDIC training has only started in 2013. Results for other types of training and the years 2011 and 2012 can be obtained upon request. Robust standard errors in parentheses; ${ }^{* *} p<0.01,{ }^{* *} p<0.05,{ }^{*} p<0.1$.

Source: OECD calculations based on RAIS data.

Control variables include the same controls as even columns in (Table 7) as well as pre-trends and pretreatment levels of GDP, employment and agricultural value added as in (Table 6). When using other variables to measure the treatment of micro regions with training courses, such as the number of training class hours per employee or the cumulative sum of training hours, the main findings are preserved (Table 9) and (Table 10) show the results for using the number of training class hours per employee. Importantly, the results are robust to the inclusion of pre-trends and pre-treatment levels in GDP, employment and agricultural value added (columns 4 until 6 in Table 9), which are strong predictors for allocation of hours of MDIC training courses to micro regions, as shown in (Table 6). This suggests that our findings are robust to concerns related to the potential endogeneity of the treatment. This is in line with other empirical studies that have shown that training courses requested by MDIC had substantial positive effects on the re-employability of unemployed workers, whereas other training courses had not (O'Connell et al., 2017[92]). (Table 10) confirms that other forms of training that were less targeted to local skill demands had much smaller effects on employment growth in micro regions. 
Table 9. Robustness checks for the results regarding MDIC training in Table 8

Differences in employment growth between regions more and less exposed to trade opening

\begin{tabular}{|c|c|c|c|c|c|c|}
\hline \multirow[t]{2}{*}{ Year of the observation $(t)$} & \multicolumn{3}{|c|}{ Without pre-treatment controls } & \multicolumn{3}{|c|}{ With pre-treatment controls } \\
\hline & (1) & (2) & (3) & (4) & (5) & (6) \\
\hline & 2013 & 2014 & 2015 & 2013 & 2014 & 2015 \\
\hline & \multicolumn{6}{|c|}{$\begin{array}{l}\text { Dependent variable: Differences in log employment (between year } t \text { and } \\
\qquad 1989 \text { ) }\end{array}$} \\
\hline \multicolumn{7}{|l|}{ Independent variables } \\
\hline \multirow{2}{*}{$\begin{array}{l}\text { Local tariff reductions (in percentage } \\
\text { points divided by 100) }\end{array}$} & $-4.868^{\star * *}$ & $-5.188^{* * *}$ & $-5.285^{\star * *}$ & $-4.361^{* * *}$ & $-4.673^{* * *}$ & $-4.726^{* * *}$ \\
\hline & $(0.729)$ & $(0.691)$ & $(0.706)$ & $(0.716)$ & $(0.684)$ & $(0.696)$ \\
\hline \multirow{2}{*}{$\begin{array}{l}\text { Interaction of local tariff reductions and } \\
\text { MDIC training class hours per employee until } 2015\end{array}$} & $2.102^{*}$ & $2.423^{* *}$ & $2.504^{* *}$ & $2.520^{* *}$ & $2.862^{* *}$ & $2.924^{\star *}$ \\
\hline & $(1.237)$ & $(1.223)$ & $(1.249)$ & $(1.245)$ & $(1.225)$ & $(1.246)$ \\
\hline \multirow[t]{2}{*}{ MDIC training class hours per employee until 2015} & $-0.347^{* *}$ & $-0.389^{* *}$ & $-0.412^{* *}$ & $-0.432^{* *}$ & $-0.480^{* * *}$ & $-0.498^{* * *}$ \\
\hline & $(0.174)$ & $(0.172)$ & $(0.177)$ & $(0.177)$ & $(0.174)$ & $(0.178)$ \\
\hline \multirow[t]{2}{*}{ GDP growth from 2010 to 2011 (in \%) } & & & & 0.458 & 0.467 & $0.576^{*}$ \\
\hline & & & & $(0.334)$ & $(0.342)$ & $(0.335)$ \\
\hline \multirow[t]{2}{*}{ Employment growth from 2010 to 2011 (in \%) } & & & & -0.066 & -0.036 & -0.083 \\
\hline & & & & $(0.298)$ & $(0.284)$ & $(0.303)$ \\
\hline \multirow{2}{*}{$\begin{array}{l}\text { Growth in agricultural value added from } 2010 \text { to } 2011 \text { (in } \\
\% \text { ) }\end{array}$} & & & & 0.017 & -0.006 & -0.034 \\
\hline & & & & $(0.165)$ & $(0.170)$ & $(0.172)$ \\
\hline \multirow[t]{2}{*}{ GDP in 2011 (in billion Reais) } & & & & $0.009^{* * *}$ & $0.008^{* * *}$ & $0.009^{* * *}$ \\
\hline & & & & $(0.003)$ & $(0.002)$ & $(0.002)$ \\
\hline \multirow[t]{2}{*}{ Employment in 2011 (in thousands) } & & & & $-0.001^{\text {***}}$ & $-0.001^{\text {***}}$ & $-0.001^{* * *}$ \\
\hline & & & & $(0.000)$ & $(0.000)$ & $(0.000)$ \\
\hline \multirow[t]{2}{*}{ Agricultural value added in 2011 (in million) } & & & & 0.000 & 0.000 & 0.000 \\
\hline & & & & $(0.000)$ & $(0.000)$ & $(0.000)$ \\
\hline Additional control variables & Yes & Yes & Yes & Yes & Yes & Yes \\
\hline State-year fixed effects & Yes & Yes & Yes & Yes & Yes & Yes \\
\hline Observations & 479 & 479 & 479 & 479 & 479 & 479 \\
\hline R-squared & 0.556 & 0.564 & 0.566 & 0.590 & 0.596 & 0.602 \\
\hline Adjusted R-squared & 0.522 & 0.531 & 0.532 & 0.553 & 0.560 & 0.565 \\
\hline
\end{tabular}

Note: Equation (4) is estimated for each year from 2013 until 2015, as MDIC training has only started in 2013. Results for other types of training and the years 2011 and 2012 can be obtained upon request. Additional control variables include the same controls as even columns in Table 7. The variable training class hours per employee was rescaled so that one unit corresponds to 5 hours of training per employee assuming an average class size of 25 trainees. Robust standard errors in parentheses; ${ }^{* *} p<0.01,{ }^{* *} p<0.05,{ }^{*} p<0.1$.

Source: OECD calculations based on RAIS data. 
Table 10. Robustness checks for the results regarding other training types in Table 8

Differences in employment growth between regions more and less exposed to trade opening

\begin{tabular}{|c|c|c|c|c|c|c|}
\hline \multirow[t]{2}{*}{ Year of the observation $(t)$} & \multicolumn{3}{|c|}{ Without pre-treatment controls } & \multicolumn{3}{|c|}{ With pre-treatment controls } \\
\hline & (1) & (2) & (3) & (4) & (5) & (6) \\
\hline & 2013 & 2014 & 2015 & 2013 & 2014 & 2015 \\
\hline & \multicolumn{6}{|c|}{$\begin{array}{l}\text { Dependent variable: Differences in log employment (between year } t \text { and } \\
\qquad 1989)\end{array}$} \\
\hline \multicolumn{7}{|l|}{ Independent variables } \\
\hline \multirow{2}{*}{$\begin{array}{l}\text { Local tariff reductions (in percentage } \\
\text { points divided by 100) }\end{array}$} & $-5.887^{* * *}$ & $-5.879^{* * *}$ & $-6.225^{* * *}$ & $-5.120^{* * *}$ & $-5.117^{\star * *}$ & $-5.370^{\star * *}$ \\
\hline & $(0.899)$ & $(0.875)$ & $(0.906)$ & $(0.890)$ & $(0.872)$ & $(0.902)$ \\
\hline \multirow{2}{*}{$\begin{array}{l}\text { Interaction of local tariff reductions and training class } \\
\text { hours per employee for other training types (non-MDIC) } \\
\text { until } 2015\end{array}$} & $0.057^{*}$ & 0.046 & $0.059^{*}$ & 0.043 & 0.033 & 0.043 \\
\hline & $(0.030)$ & $(0.029)$ & $(0.033)$ & $(0.030)$ & $(0.028)$ & $(0.032)$ \\
\hline \multirow{2}{*}{$\begin{array}{l}\text { Training class hours per employee for other training } \\
\text { types (non-MDIC) until } 2015\end{array}$} & -0.005 & -0.004 & -0.005 & -0.006 & -0.004 & -0.006 \\
\hline & $(0.004)$ & $(0.004)$ & $(0.005)$ & $(0.004)$ & $(0.004)$ & $(0.005)$ \\
\hline \multirow[t]{2}{*}{ GDP growth from 2010 to 2011 (in \%) } & & & & 0.424 & 0.421 & 0.533 \\
\hline & & & & $(0.339)$ & $(0.350)$ & $(0.338)$ \\
\hline \multirow[t]{2}{*}{ Employment growth from 2010 to 2011 (in \%) } & & & & -0.059 & -0.034 & -0.080 \\
\hline & & & & $(0.304)$ & $(0.287)$ & $(0.307)$ \\
\hline \multirow[t]{2}{*}{$\begin{array}{l}\text { Growth in agricultural value added from } 2010 \text { to } 2011 \text { (in } \\
\% \text { ) }\end{array}$} & & & & 0.033 & 0.012 & -0.016 \\
\hline & & & & $(0.162)$ & $(0.169)$ & $(0.169)$ \\
\hline \multirow[t]{2}{*}{ GDP in 2011 (in billion Reais) } & & & & $0.008^{* * *}$ & $0.008^{* * *}$ & $0.009^{* * *}$ \\
\hline & & & & $(0.002)$ & $(0.002)$ & $(0.002)$ \\
\hline \multirow[t]{2}{*}{ Employment in 2011 (in thousands) } & & & & $-0.001^{* * *}$ & $-0.001^{* * *}$ & $-0.001^{* * *}$ \\
\hline & & & & $(0.000)$ & $(0.000)$ & $(0.000)$ \\
\hline \multirow[t]{2}{*}{ Agricultural value added in 2011 (in million) } & & & & 0.000 & 0.000 & 0.000 \\
\hline & & & & $(0.000)$ & $(0.000)$ & $(0.000)$ \\
\hline Additional control variables & Yes & Yes & Yes & Yes & Yes & Yes \\
\hline State-year fixed effects & Yes & Yes & Yes & Yes & Yes & Yes \\
\hline Observations & 479 & 479 & 479 & 479 & 479 & 479 \\
\hline R-squared & 0.558 & 0.564 & 0.566 & 0.589 & 0.593 & 0.598 \\
\hline Adjusted R-squared & 0.525 & 0.531 & 0.533 & 0.551 & 0.555 & 0.561 \\
\hline
\end{tabular}

Note: Equation (4) is estimated for each year from 2013 until 2015, as MDIC training has only started in 2013. Results for other types of training and the years 2011 and 2012 can be obtained upon request. Additional control variables include the same controls as even columns in Table 7. The variable training class hours per employee was rescaled so that one unit corresponds to 5 hours of training per employee assuming an average class size of 25 trainees. Robust standard errors in parentheses; ${ }^{* * *} p<0.01,{ }^{* *} p<0.05,{ }^{*} p<0.1$.

Source: OECD calculations based on RAIS data.

In addition, analysis using a propensity score-matching estimator supports these results. Using pre-trends and pre-treatment levels of GDP, employment and agricultural value added as determinants of the treatment, i.e. the presence of MDIC training courses in a micro region, this estimator constructs propensity scores to match pairs of micro regions with similar probability of training but different treatment status (Cameron and Trivedi, 2005[93]). On average, the presence of MDIC training from 2013 until 2015 has significantly increased employment levels by $52 \%$ compared to similar micro regions without treatment. More detailed results can be obtained from the authors upon request. 


\section{References}

Aguiar, A., B. Narayanan and R. McDougall (2016), "An Overview of the GTAP 9 Data Base", Journal of Global Economic Analysis, Vol. 1/1, pp. 181-208, http://dx.doi.org/10.21642/igea.010103af.

Almeida, R. and T. Packard (2018), Skills and Jobs in Brazil: An Agenda for Youth, World Bank, Washington, DC, http://dx.doi.org/10.1596/978-1-4648-1293-4.

Amiti, M. and A. Khandelwal (2013), "Import Competition and Quality Upgrading", The Review of Economics and Statistics, Vol. 95/2, pp. 476-490, https://www.mitpressjournals.org/doi/pdf/10.1162/REST a 00271 (accessed on 22 September 2018).

Amiti, M. and A. Khandelwal (2013), "IMPORT COMPETITION AND QUALITY UPGRADING", The Review of Economics and Statistics, Vol. 95/2, pp. 476-490, https://www.mitpressjournals.org/doi/pdf/10.1162/REST a 00271 (accessed on 22 September 2018).

Amiti, M. and J. Konings (2007), "Trade Liberalization, Intermediate Inputs, and Productivity: Evidence from Indonesia”, American Economic Review, Vol. 97/5, pp. 1611-1638, http://dx.doi.org/10.1257/aer.97.5.1611.

Amiti, M., S. Redding and D. Weinstein (2019), "The Impact of the 2018 Trade War on U.S. Prices and Welfare", National Bureau of Economic Research, Cambridge, MA, http://dx.doi.org/10.3386/w25672.

Andrews, D., C. Criscuolo and P. Gal (2015), "Frontier Firms, Technology Diffusion and Public Policy: Micro Evidence from OECD Countries", OECD Productivity Working Papers, No. 2, OECD Publishing, Paris, https://dx.doi.org/10.1787/5jrq|2q2ij7b-en.

Araújo, B. and L. Paz (2014), "The effects of exporting on wages: An evaluation using the 1999 Brazilian exchange rate devaluation", Journal of Development Economics, Vol. 111, pp. 1-16, http://dx.doi.org/10.1016/j.jdeveco.2014.07.005.

Arnold, J. and R. Grundke (2021), "Raising productivity through structural reforms in Brazil", OECD Economics Department Working Papers, No. 1660, OECD, Paris, France, http://www.oecd.org/economy/economicsdepartmentworkingpapers.htm (accessed on 2 February 2021).

Arnold, J. et al. (2016), "Services Reform and Manufacturing Performance: Evidence from India", Economic Journal, Vol. 126/590, http://dx.doi.org/10.1111/ecoj.12206.

Arnold, J., B. Javorcik and A. Mattoo (2011), "Does services liberalization benefit manufacturing firms?. Evidence from the Czech Republic", Journal of International Economics, Vol. 85/1, http://dx.doi.org/10.1016/i.jinteco.2011.05.002.

Arntz, M., T. Gregory and U. Zierahn (2016), "The Risk of Automation for Jobs in OECD Countries: A Comparative Analysis", OECD Social, Employment and Migration Working Papers, No. 189, OECD Publishing, Paris, https://dx.doi.org/10.1787/5j|z9h56dvq7-en. 
Autor, D. and D. Dorn (2013), "The growth of low-skill service jobs and the polarization of the US Labor Market”, American Economic Review, Vol. 103/5, pp. 1553-1597, http://dx.doi.org/10.1257/aer.103.5.1553.

Autor, D., D. Dorn and G. Hanson (2013), "The China syndrome: Local labor market effects of import competition in the United States", American Economic Review, Vol. 103/6, pp. 21212168, http://dx.doi.org/10.1257/aer.103.6.2121.

Autor, D. et al. (2014), "Trade Adjustment: Worker-Level Evidence *”, The Quarterly Journal of Economics, Vol. 129/4, pp. 1799-1860, http://dx.doi.org/10.1093/qje/qju026.

Bartik, T. (1991), Who benefits from state and local economic development policies?, Kalamazoo, MI: W.E. Upjohn Institute forEmployment Research.

Bas, M. (2012), "Input-trade liberalization and firm export decisions: Evidence from Argentina", Journal of Development Economics, Vol. 97/2, pp. 481-493, http://dx.doi.org/10.1016/J.JDEVECO.2011.05.010.

Bechichi, N. et al. (2018), "Moving between jobs: An analysis of occupation distances and skill needs", OECD Science, Technology and Innovation Policy Papers, No. 52, OECD, Paris, http://www.oecd.org/going-digital (accessed on 27 September 2018).

Bechichi, N. et al. (2019), "Occupational mobility, skills and training needs", http://www.oecd.org/going-digital. (accessed on 26 January 2020).

Becker, S., K. Ekholm and M. Muendler (2013), "Offshoring and the onshore composition of tasks and skills", Journal of International Economics, Vol. 90/1, pp. 91-106, http://dx.doi.org/10.1016/j.jinteco.2012.10.005.

Becker, S. and M. Muendler (2015), "Trade and tasks: an exploration over three decades in Germany”, Economic Policy, Vol. 30/84, pp. 589-641, http://dx.doi.org/10.1093/epolic/eiv014.

Blalock, G. and F. Veloso (2007), "Imports, Productivity Growth, and Supply Chain Learning", World Development, Vol. 35/7, pp. 1134-1151, http://dx.doi.org/10.1016/i.worlddev.2006.10.009.

Bloom, N. and J. Reenen (2010), "Why do management practices differ across firms and countries?", Journal of Economic Perspectives, Vol. 24/1, pp. 203-224, http://dx.doi.org/10.1257/jep.24.1.203.

Blyde, J. et al. (2019), "Training and Labor Adjustment to Trade", IDB WORKING PAPER SERIES, No. No IDB-WP-01069, Inter-American Development Bank, Washington, D.C., http://dx.doi.org/10.18235/0001970.

Brambilla, I., N. Depetris Chauvin and G. Porto (2017), "Examining the Export Wage Premium in Developing Countries", Review of International Economics, Vol. 25/3, pp. 447-475, http://dx.doi.org/10.1111/roie.12231.

Brown, A. and J. Koettl (2012), "Active Labor Market Programs: Employment Gain or Fiscal Drain?", IZA Discussion papers, No. 6880, IZA.

Broxterman, D. and W. Larson (2020), "An empirical examination of shift-share instruments", Journal of Regional Science, p. jors.12481, http://dx.doi.org/10.1111/jors.12481. 
Cadot, O., J. Gourdon and F. van Tongeren (2018), "Estimating Ad Valorem Equivalents of Non[46] Tariff Measures: Combining Price-Based and Quantity-Based Approaches", OECD Trade Policy Papers, No. 215, OECD Publishing, Paris, https://dx.doi.org/10.1787/f3cd5bdc-en.

Cameron, A. and P. Trivedi (2005), Microeconometrics - Methods and Applications, Cambridge University Press.

Cavgias, A. et al. (2019), Edited Democracy: Media Manipulation and the News Coverage of Presidential Debates., Working Papers, Department of Economics 2019_17, University of São Paulo (FEA-USP).

Cavgias, A. et al. (2019), Edited Democracy: Media Manipulation and the News Coverage of Presidential Debates.

Costa, F., J. Garred and J. Pessoa (2016), "Winners and losers from a commodities-formanufactures trade boom", Journal of International Economics, Vol. 102, pp. 50-69, http://dx.doi.org/10.1016/i.jinteco.2016.04.005.

Criscuolo, C., P. Gal and C. Menon (2014), "The Dynamics of Employment Growth: New Evidence from 18 Countries”, OECD Science, Technology and Industry Policy Papers, No. 14, OECD Publishing, Paris, https://dx.doi.org/10.1787/5jz417hj6hg6-en.

Criscuolo, C. and J. Timmis (2018), "The Changing Structure of Global Value Chains: Are Central Hubs Key for Productivity?", International Productivity Monitor, Vol. 34, pp. 64-80, https://ideas.repec.org/a/sls/ipmsls/v34y20184.html (accessed on 4 October 2018).

De Loecker, J. et al. (2016), "Prices, Markups, and Trade Reform", Econometrica, Vol. 84/2, pp. 445-510, http://dx.doi.org/10.3982/ECTA11042.

Dix-Carneiro, R. and B. Kovak (2017), "Trade liberalization and regional dynamics", American Economic Review, Vol. 107/10, pp. 2908-2946, http://dx.doi.org/10.1257/aer.20161214.

Dix-Carneiro, R., R. Soares and G. Ulyssea (2018), "Economic shocks and crime: Evidence from the Brazilian trade liberalization", American Economic Journal: Applied Economics, Vol. 10/4, pp. 158-195, http://dx.doi.org/10.1257/app.20170080.

Dutz, M. (2018), Jobs and Growth: Brazil's Productivity Agenda, The World Bank, http://dx.doi.org/10.1596/978-1-4648-1320-7.

Economistas do Brasil (2018), Carta Brasil - Um conjunto de propostas para o novo governo, https://iepecdg.com.br/wp-content/uploads/2018/11/Carta-BRASIL-01.11.2018logo.pdf.

Fiorini, M., M. Sanfilippo and A. Sundaram (2019), "Roads: From Trade Liberalization to Firm Productivity", Robert Schuman Centre for Advanced Studies Research Paper No. RSCAS, No. 32, http://dx.doi.org/10.2139/ssrn.3393548.

Gathmann, C., I. Helm and U. Schönberg (2018), "Spillover effects of mass layoffs", Journal of the European Economic Association, http://dx.doi.org/10.1093/jeea/jvy045.

Gathmann, C., I. Helm and U. Schönberg (2018), "SPILLOVER EFFECTS OF MASS LAYOFFS", Journal of the European Economic Association, http://dx.doi.org/10.1093/jeea/jvy045. 
Goldberg, K. and N. Pavcnik (2007), Distributional Effects of Globalization in Developing Countries, https://pubs.aeaweb.org/doi/pdfplus/10.1257/jel.45.1.39 (accessed on 14 September 2018).

Goldberg, P. et al. (2009), "Trade Liberalization and New Imported Inputs", American Economic Review, Vol. 99/2, pp. 494-500, http://dx.doi.org/10.1257/aer.99.2.494.

Goldberg, P. and N. Pavcnik (2003), "The response of the informal sector to trade liberalization", Journal of Development Economics, Vol. 72/2, pp. 463-496, http://dx.doi.org/10.1016/S03043878(03)00116-0.

Grollmann, P. et al. (2016), Duale Ausbildung als betriebliche Strategie der Fachkräftesicherung - Fallstudien zu Motivation und Organisation im internationalen Vergleich, Bundesinstitut fuer Berufsbildung - Bonn, https://www.bibb.de/tools/dapro/data/documents/pdf/zw 15312.pdf.

Grundke, R. and J. Arnold (2019), "Fostering Argentina's integration into the world economy", OECD Economics Department Working Papers, No. 1572, OECD Publishing, Paris, https://dx.doi.org/10.1787/7ed95b2b-en.

Grundke, R. et al. (2018), "Which skills for the digital era?: Returns to skills analysis", OECD Science, Technology and Industry Working Papers, No. 2018/09, OECD Publishing, Paris, https://dx.doi.org/10.1787/9a9479b5-en.

Heckman, J. et al. (2010), "The Rate of Return to the High/Scope Perry Preschool Program", Journal of Political Economy, Vol. 94/1-2, pp. 114-128.

Heckman, J. and S. Mosso (2014), "The Economics of Human Development and Social Mobility", Annual Review of Economcs, Vol. 6, pp. 689-733, http://dx.doi.org/10.1146/annurev-economics-080213-040753.

Heckman, J., R. Pinto and P. Savelyev (2013), "Understanding the mechanisms through which an influential early childhood program boosted adult outcomes", American Economic Review, Vol. 103/6, pp. 2052-2086, http://dx.doi.org/10.1257/aer.103.6.2052.

Hirata, G. and R. Soares (2016), "Competition and the Racial Wage Gap: Testing Becker's Model of Employer Discrimination", IZA Discussion Paper Series, No. 9764.

Hsieh, C. and P. Klenow (2009), "Misallocation and Manufacturing TFP in China", The Quarterly Journal of Economics, Vol. 124/4, pp. 1403-1448, https://www.jstor.org/stable/pdf/40506263.pdf (accessed on 17 January 2019).

Hummels, D. et al. (2012), "Offshoring, Transition, and Training: Evidence from Danish Matched Worker-Firm Data", American Economic Review: Papers \& Proceedings, Vol. 102/3, pp. 424428, http://dx.doi.org/10.1257/aer.102.3.424.

Hummels, D., J. Munch and C. Xiang (2018), Offshoring and labor markets, American Economic Association, http://dx.doi.org/10.1257/jel.20161150.

Hyman, B. (2018), "Can Displaced Labor Be Retrained? Evidence from Quasi-Random Assignment to Trade Adjustment Assistance", SSRN Electronic Journal, http://dx.doi.org/10.2139/ssrn.3155386.

Hyman, B. (2018), "Can Displaced Labor Be Retrained? Evidence from Quasi-Random Assignment to Trade Adjustment Assistance *". 
IBGE (2019), Síntese de Indicadores Sociais - Uma análise das condições de vida da população brasileira 2019, https://biblioteca.ibge.gov.br/visualizacao/livros/liv101629.pdf.

IBGE (2016), Pesquisa nacional de saúde do escolar 2015, Instituto Brasileiro de Geografia e Estadisticas, https://biblioteca.ibge.gov.br/visualizacao/livros/liv97870.pdf.

INSPER (2017), Políticas públicas para redução do abandono e evasão escolar de jovens, http://gesta.org.br/wp-content/uploads/2017/09/Politicas-Publicas-para-reducao-doabandono-e-evasao-escolar-de-jovens.pdf.

Kovak, B. (2013), "Regional Effects of Trade Reform: What is the Correct Measure of Liberalization? †", American Economic Review, Vol. 103/5, pp. 1960-1976, http://dx.doi.org/10.1257/aer.103.5.1960.

Kume, H., G. Piani and C. Braz de Sousa (2003), "A POLÍTICA BRASILEIRA DE IMPORTAÇÃO NO PERÍODO 1987-1998: DESCRIÇÃO E AVALIAÇÃO”, in Corseuil, C. and H. Kume (eds.), A Abertura Comercial Brasileira nos Anos 1990 : impactos sobre emprego e salário, IPEA, Rio de Janeiro.

Lyon, S. and M. Waugh (2018), "Redistributing the gains from trade through progressive taxation", Journal of International Economics, Vol. 115, pp. 185-202, http://dx.doi.org/10.1016/j.jinteco.2018.09.008.

McDonald, S. and K. Thierfelder (2013), Globe v2: A SAM based global CGE model using GTAP data - Model Documentation, http://cgemod.org.uk/Global\%20CGE\%20Model\%20v2.pdf.

Melitz, M. (2003), The Impact of Trade on Intra-Industry Reallocations and Aggregate Industry Productivity, https://www.jstor.org/stable/pdf/1555536.pdf?refreqid=excelsior\%3Ae3382ca8aee44f583882d 975e0cdb85e (accessed on 22 September 2018).

Menezes-Filho, N. and M. Muendler (2011), "Labor Reallocation in Response to Trade Reform", NBER Working Paper, No. 17372, National Bureau of Economic Research, Cambridge, MA, http://dx.doi.org/10.3386/w17372.

NAO (2019), The apprenticeships programme, National Audit Office, https://www.nao.org.uk/wpcontent/uploads/2019/03/The-apprenticeships-programme.pdf.

O'Connell, S. et al. (2017), "Can Business Input Improve the Effectiveness of Worker Training? Evidence from Brazil's Pronatec-MDIC", Policy Research Working Paper, No. 8155, World Bank, Washington DC, http://econ.worldbank.org. (accessed on 19 February 2020).

O'Connell, S. et al. (2017), "Can Business Input Improve the Effectiveness of Worker Training? Evidence from Brazil's Pronatec-MDIC", Policy Research Working Paper, No. 8155, World Bank, Washington DC, http://econ.worldbank.org. (accessed on 19 February 2020).

O'Connell, S. et al. (2017), "Can business input improve the effectiveness of worker training? evidence from Brazil's Pronatec-MDIC", Policy Research Working Paper, No. WPS8155, World Bank, http://documents.worldbank.org/curated/en/444871501522977352/Canbusiness-input-improve-the-effectiveness-of-worker-training-evidence-from-Brazils-PronatecMDIC (accessed on 5 October 2018).

OECD (2020), OECD Economic Surveys: Brazil 2020, OECD Publishing, Paris, https://dx.doi.org/10.1787/250240ad-en. 
OECD (2019), Education at a Glance, https://doi.org/10.1787/f8d7880d-en.

OECD (2019), Financial Incentives to Promote Adult Learning in Australia, Getting Skills Right, OECD Publishing Paris, https://doi.org/10.1787/c79badcc-en.

OECD (2019), Getting Skills Right: Future-Ready Adult Learning Systems, Getting Skills Right, OECD Publishing Paris, https://doi.org/10.1787/9789264311756-en.

OECD (2019), OECD Economic Surveys: Malaysia, OECD Publishing Paris, https://doi.org/10.1787/eaaa4190-en.

OECD (2019), OECD Skills Outlook 2019 : Thriving in a Digital World, OECD Publishing, Paris, https://dx.doi.org/10.1787/df80bc12-en.

OECD (2019), PISA 2018 Results (Vol II): Where all students can succeed., OECD Publishing Paris, https://doi.org/10.1787/b5fd1b8f-en.

OECD (2018), Fostering Brazil's integration into the world economy, OECD Publishing, https://doi.org/10.1787/eco surveys-bra-2018-5-en (accessed on 7 February 2020).

OECD (2018), Getting Skills Right: Brazil, Getting Skills Right, OECD Publishing, Paris, https://dx.doi.org/10.1787/9789264309838-en.

OECD (2018), Getting Skills Right: Brazil,, https://doi.org/10.1787/9789264309838-en.

OECD (2018), Job Creation and Local Economic Development 2018: Preparing for the Future of Work, OECD Publishing, Paris, https://dx.doi.org/10.1787/9789264305342-en.

OECD (2017), "How to make trade work for all", OECD Publishing, Paris, https://dx.doi.org/10.1787/eco outlook-v2017-1-3-en.

OECD (2017), OECD Skills Outlook 2017: Skills and Global Value Chains, OECD Publishing, Paris, https://dx.doi.org/10.1787/9789264273351-en.

OECD (2016), Understanding social impact bonds, OECD, Paris, http://www.oecd.org/cfe/leed/UnderstandingSIBsLux-WorkingPaper.pdf (accessed on 19 February 2020).

OECD (2015), "METRO VERSION 1 MODEL DOCUMENTATION", Working Party of the Trade Committee, No. TAD/TC/WP(2014)24/FINAL, OECD, Paris, https://one.oecd.org/document/TAD/TC/WP(2014)24/FINAL/en/pdf (accessed on 3 February 2021).

Pavcnik, N. (2002), "Trade Liberalization, Exit, and Productivity Improvements: Evidence from Chilean Plants", The Review of Economic Studies, Vol. 69/1, pp. 245-276, http://dx.doi.org/10.1111/1467-937X.00205.

Rusticelli, E. et al. (2018), "Going local: a regional perspective on how trade affects labour markets and inequality", OECD Economics Department Working Papers, No. 1530, OECD Publishing, Paris, https://dx.doi.org/10.1787/2981f94c-en.

Schwab, K. (2019), The Global Competitiveness Report 2019, World Economic Forum, http://www3.weforum.org/docs/WEF TheGlobalCompetitivenessReport2019.pdf (accessed on 19 February 2020). 
Silva, J., R. Almeida and V. Strokova (2015), Sustaining Employment and Wage Gains in Brazil: [39] A Skills and Jobs Agenda, The World Bank, http://dx.doi.org/10.1596/978-1-4648-0644-5.

Spitz-Oener, A. (2006), "Technical Change, Job Tasks, and Rising Educational Demands: Looking outside the Wage Structure", Journal of Labor Economics, Vol. 24/2, pp. 235-270, http://dx.doi.org/10.1086/499972.

Todos pela educação (2018), Educação ja - Uma proposta suprapartidária de estratégia para a Educação Básica brasileira e prioridades para Governo Federal em 2019-2022.

Topalova, P. (2010), "Factor immobility and regional impacts of trade liberalization: Evidence on poverty from India", American Economic Journal: Applied Economics, Vol. 2/4, pp. 1-41, http://dx.doi.org/10.1257/app.2.4.1.

Topalova, P. and A. Khandelwal (2011), "Trade Liberalization and firm productivity: The case of India", The Review of Economics and Statistics, Vol. 93/3, pp. 995-1009, http://dx.doi.org/10.1162/REST a 00095.

Topalova, P. and A. Khandelwal (2011), "TRADE LIBERALIZATION AND FIRM PRODUCTIVITY: THE CASE OF INDIA", The Review of Economics and Statistics, Vol. 93/3, pp. 995-1009, http://dx.doi.org/10.1162/REST a 00095.

Winters, L., N. Mcculloch and A. Mckay (2004), "Trade Liberalization and Poverty: The Evidence so Far", Journal of Economic Literature, Vol. 42/1, pp. 72-115, https://www.jstor.org/stable/pdf/3217037.pdf?refreqid=excelsior\%3Afb2fd700a65867707fddc5 44b380482d (accessed on 14 September 2018).

World Bank (2016), Brazil Systematic Country Diagnostic: Retaking the path to Inclusion, Growth and Sustainability, The World Bank Group. 